Prepared in cooperation with the Klamath Water and Power Agency and the Oregon Water Resources Department

\title{
Evaluation of Alternative Groundwater-Management Strategies for the Bureau of Reclamation Klamath Project, Oregon and California
}

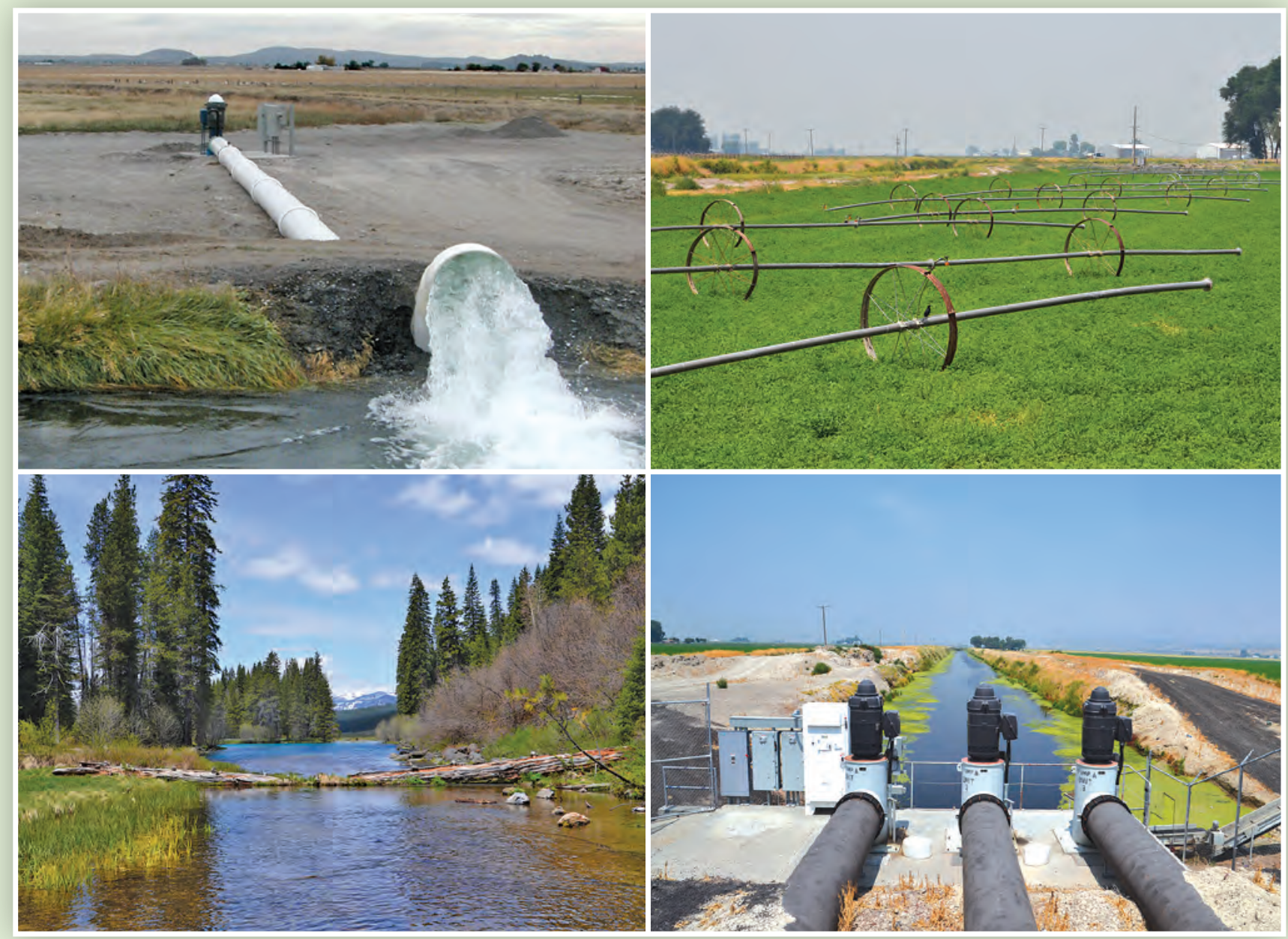

Scientific Investigations Report 2014-5054 
Cover:

Upper left: Tulelake Irrigation District well number 1, discharging to a canal, Bureau of Reclamation Klamath Project, California (photograph taken by Marshall Gannett, U.S. Geological Survey, October 2001).

Upper right: Irrigated farmland, Tulelake Irrigation District, Bureau of Reclamation Klamath Project, California (photograph taken by Brian Wagner, U.S. Geological Survey, August 2013).

Lower right: Tulelake Irrigation District pumping plant $A$, Bureau of Reclamation Klamath Project, California (photograph taken by Brian Wagner, U.S. Geological Survey, August 2013).

Lower left: Wood River headwaters, Oregon (photograph taken by Brian Wagner, U.S. Geological Survey, May 2011). 


\section{Evaluation of Alternative Groundwater- Management Strategies for the Bureau of Reclamation Klamath Project, Oregon and California}

By Brian J. Wagner and Marshall W. Gannett

Prepared in cooperation with the Klamath Water and Power Agency and the Oregon Water Resources Department

Scientific Investigations Report 2014-5054 


\title{
U.S. Department of the Interior SALLY JEWELL, Secretary
}

\section{U.S. Geological Survey Suzette M. Kimball, Acting Director}

\author{
U.S. Geological Survey, Reston, Virginia: 2014
}

For more information on the USGS - the Federal source for science about the Earth, its natural and living resources, natural hazards, and the environment, visit http://www.usgs.gov or call 1-888-ASK-USGS.

For an overview of USGS information products, including maps, imagery, and publications, visit http://www.usgs.gov/pubprod

To order this and other USGS information products, visit http://store.usgs.gov

Any use of trade, firm, or product names is for descriptive purposes only and does not imply endorsement by the U.S. Government.

Although this information product, for the most part, is in the public domain, it also may contain copyrighted materials as noted in the text. Permission to reproduce copyrighted items must be secured from the copyright owner.

Suggested citation:

Wagner, B.J. and Gannett, M.W., 2014, Evaluation of alternative groundwater-management strategies for the Bureau of Reclamation Klamath Project, Oregon and California: U.S. Geological Survey Scientific Investigations Report 20145054, 48 p., http://dx.doi.org/10.3133/sir20145054.

ISSN 2328-0328 (online) 


\section{Contents}

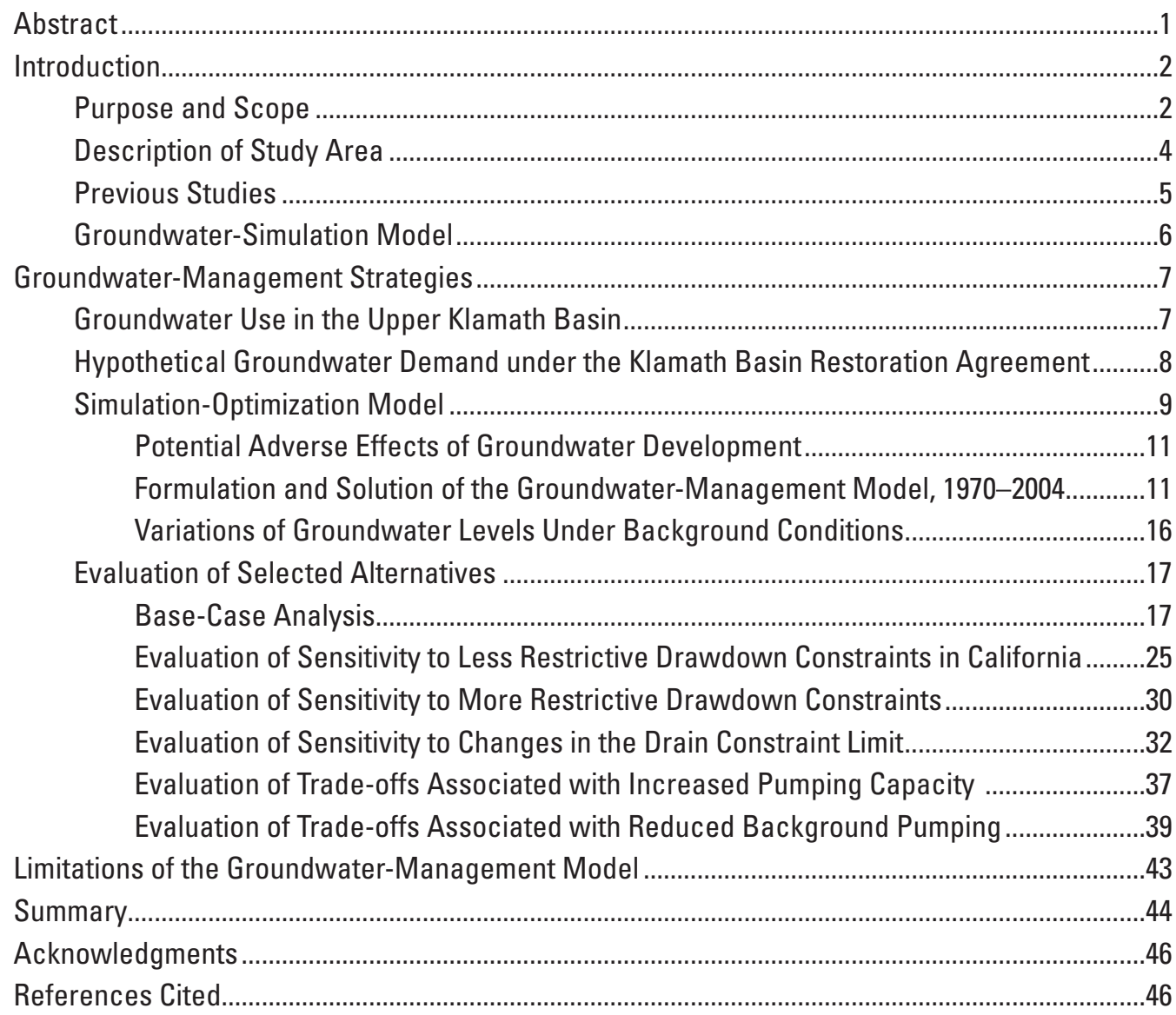

\section{Figures}

1. Map showing locations of major geographic features, upper Klamath Basin, Oregon and California .

2. Graph showing supplemental groundwater volume purchased for the Bureau of Reclamation Klamath Irrigation Project, upper Klamath Basin, Oregon and California, 2001-10.

3. Graphs showing estimated irrigation demand from Upper Klamath Lake to the Bureau of Reclamation Klamath Irrigation Project (Project) and hypothetical irrigation deliveries based on limits defined in the Klamath Basin Restoration Agreement, and hypothetical Project groundwater demand, upper Klamath Basin, Oregon and California, 1970-2004...

4. Maps showing locations of managed wells and drawdown and discharge constraints, upper Klamath Basin, Oregon and California

5. Graph showing results of base-case optimization model: hypothetical groundwater demand and optimized annual groundwater withdrawal, upper Klamath Basin, Oregon and California, 1970-2004 


\section{Figures-Continued}

6. Map showing frequency of optimized-well usage in base-case groundwatermanagement analysis, upper Klamath Basin, Oregon and California

7. Maps showing frequency of binding drawdown constraints in the base-case groundwater-management analysis for 3rd quarter seasonal-drawdown constraints; 4th quarter seasonal-drawdown constraints; and year-to-year drawdown constraints, upper Klamath Basin, Oregon and California

8. Graph showing sensitivity of optimization results to less restrictive drawdownconstraint limits in the California part of the model, upper Klamath Basin, Oregon and California, 1970-2004.

9. Graphs showing calculated annual groundwater withdrawals by pumping region for the base-case groundwater-management analysis and analysis of less restrictive drawdown-constraint limits for annual pumping in the southern Tule Lake region; annual pumping in the northern Tule Lake region; and annual pumping in the Klamath Valley region, upper Klamath Basin, Oregon and California, 1970-2004.

10. Graph showing sensitivity of optimization results to more restrictive drawdownconstraint limits, upper Klamath Basin, Oregon and California, 1970-2004

11. Graphs showing calculated annual groundwater withdrawals by pumping region for the base-case groundwater-management analysis and analysis of more restrictive drawdown-constraint limits for annual pumping in the southern Tule Lake region; annual pumping in the northern Tule Lake region; and annual pumping in the Klamath Valley region, upper Klamath Basin, Oregon and California, 1970-2004.

12. Graph showing sensitivity of optimization results to changes in the allowable reduction of groundwater discharge to the Bureau of Reclamation Klamath Irrigation Project drain system, upper Klamath Basin, Oregon and California, 1970-2004

13. Graph showing sensitivity of optimization results to changes in the allowable reduction of groundwater discharge to the Bureau of Reclamation Klamath Irrigation Project drain system.

14. Graphs showing calculated annual groundwater withdrawals by pumping region for the base-case groundwater-management analysis and analyses of alternative drain-discharge-constraint limits for annual pumping in the southern Tule Lake region; annual pumping in the northern Tule Lake region, and annual pumping in the Klamath Valley region, upper Klamath Basin, Oregon and California, 1970-2004.

15. Graph showing sensitivity of optimization results to additional pumping capacity at network of wells serving the Bureau of Reclamation Klamath Irrigation Project, upper Klamath Basin, Oregon and California, 1970-2004

16. Graphs showing calculated annual groundwater withdrawals by pumping region for the base-case groundwater-management analysis and analysis of increased pumping capacity for annual pumping in the southern Tule Lake region; annual pumping in the northern Tule Lake region; and annual pumping in the Klamath Valley region, upper Klamath Basin, Oregon and California, 1970-2004 


\section{Figures-Continued}

17. Graph showing summary of background pumping removed from model, upper Klamath Basin, Oregon and California, 1970-2004.

18. Graph showing sensitivity of optimization results to removal of selected background pumping, upper Klamath Basin, Oregon and California, 1970-2004

19. Graphs showing calculated annual groundwater withdrawals by pumping region for the base-case analysis and analysis of reduced background pumping for annual pumping in the southern Tule Lake region; annual pumping in the northern Tule Lake region; and annual pumping in the Klamath Valley region, upper Klamath Basin, Oregon and California, 1970-2004.

\section{Tables}

1. Summary of alternative groundwater-management strategies evaluated, upper Klamath Basin, Oregon and California.

2. Calculated quarterly withdrawals by pumping region and year for the base-case groundwater-management analysis, upper Klamath Basin, Oregon and California, 1970-2004.

3. Calculated quarterly withdrawals by pumping region and year based on analysis of less restrictive drawdown-constraint limits in the California part of the groundwater-management model for scenario DD_1, upper Klamath Basin, Oregon and California, 1970-2004.

4. Calculated quarterly withdrawals by pumping region and year based on analysis of less restrictive drawdown-constraint limits in the California part of the groundwater-management model for scenario DD_2, upper Klamath Basin, Oregon and California, 1970-2004.

5. Calculated quarterly withdrawals by pumping region and year based on analysis of more restrictive drawdown-constraint limits for scenario DD_3, upper Klamath Basin, Oregon and California, 1970-2004.

6. Calculated quarterly withdrawals by pumping region and year based on analysis of more restrictive drain-constraint limit for scenario Drain_10, upper Klamath Basin, Oregon and California, 1970-2004.

7. Calculated quarterly withdrawals by pumping region and year based on analysis of more restrictive drain-constraint limit for scenario Drain_05, upper Klamath Basin, Oregon and California, 1970-2004.

8. Calculated quarterly withdrawals by pumping region and year based on analysis of additional pumping capacity, upper Klamath Basin, Oregon and California, 1970-2004.

9. Calculated quarterly withdrawals by pumping region and year based on analysis of removal of selected background pumping, upper Klamath Basin, Oregon and California, 1970-2004. 


\title{
Conversion Factors and Datums
}

\author{
Conversion Factors
}

Inch/Pound to SI

\begin{tabular}{|c|c|c|}
\hline Multiply & By & To obtain \\
\hline \multicolumn{3}{|c|}{ Length } \\
\hline inch (in.) & 2.54 & centimeter $(\mathrm{cm})$ \\
\hline inch (in.) & 25.4 & millimeter $(\mathrm{mm})$ \\
\hline foot $(\mathrm{ft})$ & 0.3048 & meter $(\mathrm{m})$ \\
\hline mile (mi) & 1.609 & kilometer $(\mathrm{km})$ \\
\hline \multicolumn{3}{|c|}{ Area } \\
\hline acre & 0.4047 & hectare (ha) \\
\hline square mile $\left(\mathrm{mi}^{2}\right)$ & 2.590 & square kilometer $\left(\mathrm{km}^{2}\right)$ \\
\hline \multicolumn{3}{|c|}{ Volume } \\
\hline cubic foot $\left(\mathrm{ft}^{3}\right)$ & 0.02832 & cubic meter $\left(\mathrm{m}^{3}\right)$ \\
\hline acre-foot (acre-ft) & 1,233 & cubic meter $\left(\mathrm{m}^{3}\right)$ \\
\hline \multicolumn{3}{|c|}{ Flow rate } \\
\hline cubic foot per second $\left(\mathrm{ft}^{3} / \mathrm{s}\right)$ & 0.02832 & cubic meter per second $\left(\mathrm{m}^{3} / \mathrm{s}\right)$ \\
\hline \multicolumn{3}{|c|}{ Hydraulic conductivity } \\
\hline foot per day (ft/d) & 0.3048 & meter per day $(\mathrm{m} / \mathrm{d})$ \\
\hline \multicolumn{3}{|c|}{ Transmissivity* } \\
\hline foot squared per day $\left(\mathrm{ft}^{2} / \mathrm{d}\right)$ & 0.09290 & meter squared per day $\left(\mathrm{m}^{2} / \mathrm{d}\right)$ \\
\hline
\end{tabular}

Temperature in degrees Fahrenheit $\left({ }^{\circ} \mathrm{F}\right)$ may be converted to degrees Celsius $\left({ }^{\circ} \mathrm{C}\right)$ as follows:

$$
{ }^{\circ} \mathrm{C}=\left({ }^{\circ} \mathrm{F}-32\right) / 1.8 \text {. }
$$

*Transmissivity: The standard unit for transmissivity is cubic foot per day per square foot times foot of aquifer thickness [(ft $\left.\left.\mathrm{ft}^{3} / \mathrm{d}\right) / \mathrm{ft}^{2}\right] \mathrm{ft}$. In this report, the mathematically reduced form, foot squared per day $\left(\mathrm{ft}^{2} / \mathrm{d}\right)$, is used for convenience.

Datums

Vertical coordinate information is referenced to the National Geodetic Vertical Datum of 1929 (NGVD 29).

Horizontal coordinate information is referenced to the North American Datum of 1927 (NAD 27). Elevation, as used in this report, refers to distance above the vertical datum. 


\title{
Evaluation of Alternative Groundwater-Management Strategies for the Bureau of Reclamation Klamath Project, Oregon and California
}

\author{
By Brian J. Wagner and Marshall W. Gannett
}

\section{Abstract}

The water resources of the upper Klamath Basin, in southern Oregon and northern California, are managed to achieve various complex and interconnected purposes. Since 2001, irrigators in the Bureau of Reclamation Klamath Irrigation Project (Project) have been required to limit surfacewater diversions to protect habitat for endangered freshwater and anadromous fishes. The reductions in irrigation diversions have led to an increased demand for groundwater by Project irrigators, particularly in drought years. The potential effects of sustained pumping on groundwater and surface-water resources have caused concern among Federal and state agencies, Indian tribes, wildlife groups, and groundwater users. To aid in the development of a viable groundwatermanagement strategy for the Project, the U.S. Geological Survey, in collaboration with the Klamath Water and Power Agency and the Oregon Water Resources Department, developed a groundwater-management model that links groundwater simulation with techniques of constrained optimization.

The overall goal of the groundwater-management model is to determine the patterns of groundwater pumping that, to the extent possible, meet the supplemental groundwater demands of the Project. To ensure that groundwater development does not adversely affect groundwater and surface-water resources, the groundwater-management model includes constraints to (1) limit the effects of groundwater withdrawal on groundwater discharge to streams and lakes that support critical habitat for fish listed under the Endangered Species Act, (2) ensure that drawdowns do not exceed limits allowed by Oregon water law, and (3) ensure that groundwater withdrawal does not adversely affect agricultural drain flows that supply a substantial portion of water for irrigators and wildlife refuges in downslope areas of the Project. Groundwater-management alternatives were tested and designed within the framework of the Klamath Basin Restoration Agreement (currently [2013] awaiting authorizing Federal legislation), which would establish a permanent limit on the amount of surface water that can be diverted annually to the Project. Groundwater-management scenarios were evaluated for the period 1970-2004; supplemental groundwater demand by the Project was estimated as the part of irrigation demand that would not have been satisfied by the surface-water diversion allowed under the Klamath Basin Restoration Agreement. Over the 35-year management period, 22 years have supplemental groundwater demand, which ranges from a few thousand acre-feet (acre-ft) to about 100,000 acre-ft in the driest years.

The results of the groundwater-management model indicate that supplemental groundwater pumping by the Project can be managed to avoid adverse effects to groundwater discharge that supports critical aquatic habitat. The existing configuration of wells in the Project would be able to meet groundwater-pumping goals in 14 of the 22 years with supplemental groundwater demand; however, substantial irrigation shortages can be expected during drought periods when the demand for supplemental groundwater is highest. The maximum irrigation-season withdrawal calculated by the groundwater-management model is about 60,000 acre-ft, the average withdrawal in drought years is about 54,000 acre- $\mathrm{ft}$, and the amount of unmet groundwater demand reaches a maximum of about 45,000 acre-ft. A comparison of optimized groundwater withdrawals by geographic region shows that the highest annual withdrawals are associated with wells in the Tule Lake and Klamath Valley regions of the Project. The patterns of groundwater withdrawal also show that a substantial amount of the available pumping capacity is unused due to the restrictions imposed by drawdown constraints.

Subsequent model applications were used to evaluate the sensitivity of optimization results to various factors. A sensitivity analysis quantified the changes in optimized groundwater withdrawals that result from changes in drawdown-constraint limits. The analysis showed the potential for substantial increases in withdrawals of groundwater with less restrictive drawdown limits at drawdown-control sites in the California part of the model. Systematic variation of the drains-constraint limit yielded a trade-off curve between optimized groundwater withdrawals and the allowable reduction in groundwater discharge to the Project drain system. Additional model applications were used to assess the value of increasing the pumping capacity of the network of wells serving the Project, and the relation between reduced off-Project groundwater pumping and increased pumping by Project irrigators. 


\section{Introduction}

The upper Klamath Basin occupies a broad volcanic plateau in the transition between the Cascade Range and the Basin and Range geologic provinces in south-central Oregon and northern California (fig. 1). Although the region is high desert, the basin receives considerable recharge from the Cascade Range on the western margin and the volcanic uplands on the eastern margin. As a result, the permeable volcanic bedrock in the basin contains a robust regional groundwater system that contributes much of the flow to the streams and lakes that serve as the principal water supply for irrigated agriculture and habitat for endangered freshwater and anadromous fishes (Gannett and others, 2007; National Marine Fisheries Service and U.S. Fish and Wildlife Service, 2013).

Water use and water needs in the upper Klamath Basin are closely related to agriculture, which is a significant component of the basin economy. The agricultural economy provides about 10 percent of the jobs in the upper Klamath Basin and about 15 percent of the economic output (National Research Council, 2004). More than 500,000 acres in the basin are irrigated, about 190,000 acres of which are within the Bureau of Reclamation Klamath Irrigation Project (Project) (Burt and Freeman, 2003; National Resources Conservation Service, 2004). The primary source of irrigation water for the Project is Upper Klamath Lake and the primary crops grown on Project land are alfalfa, irrigated pasture, and grain. Between 2005 and 2009, crops grown on Project land provided an average annual revenue of $\$ 148.6$ million (U.S. Department of the Interior and others, 2012).

Prior to 2001, annual diversions by the Project from Upper Klamath Lake and the Klamath River were as much as about 490,000 acre-ft (McFarland and others, 2005). In 2001, water-management priorities in the basin shifted to protect aquatic habitat. A series of Endangered Species Act biological opinions now require the Project to limit surface-water diversions to protect habitat for Lost River and shortnose suckers and coho salmon (National Marine Fisheries Service and U.S. Fish and Wildlife Service, 2013). This realignment of water supply and demand has resulted in reductions in surface water diverted for agriculture and increased demand for groundwater, particularly in drought years.
In order to balance the benefits of water for aquatic wildlife and agriculture, stakeholders in the basin developed the Klamath Basin Restoration Agreement (KBRA; 2010), a framework for water-resources management jointly developed by Federal, state, and county agencies, Indian tribes, irrigation communities, and conservation and fishing groups. The primary goals of the KBRA are to restore historical fish habitat and populations and establish reliable water supplies for irrigation. To achieve these goals, the KBRA includes elements related to water diversion and use that substantially change water-resources-management practices in the basin. Among those is the Water Resources Program (Klamath Basin Restoration Agreement, 2010, section 15), which establishes a permanent limit on the amount of water that can be diverted to the Project from Upper Klamath Lake and the Klamath River. A comparison of historical diversion amounts to the maximum diversion amounts permitted by the KBRA indicates the Project could experience irrigation deficits of about 100,000 acre-ft in the driest years.

The shift in water-management priorities is expected to create a sustained demand for groundwater to supplement reduced surface-water diversions to the Project. There is concern that the effects of increased groundwater use by the Project could spread beyond the Project pumping centers to other parts of the basin, with the possibility for adverse effects on groundwater users outside the Project (off-Project water users) and surface-water resources that are critical to aquatic wildlife. The competing demands on the groundwater resources of the upper Klamath Basin are creating a need for improved techniques to better understand and manage the groundwater development in the area.

\section{Purpose and Scope}

Sound management of the water resources of the upper Klamath Basin requires understanding the complex and interconnected groundwater and surface-water systems of the region. The U.S. Geological Survey (USGS) completed studies to characterize the regional groundwater system in the basin (Gannett and others, 2007) and develop groundwatersimulation and management models of the region (Gannett and others, 2012). In order to understand the broad and 


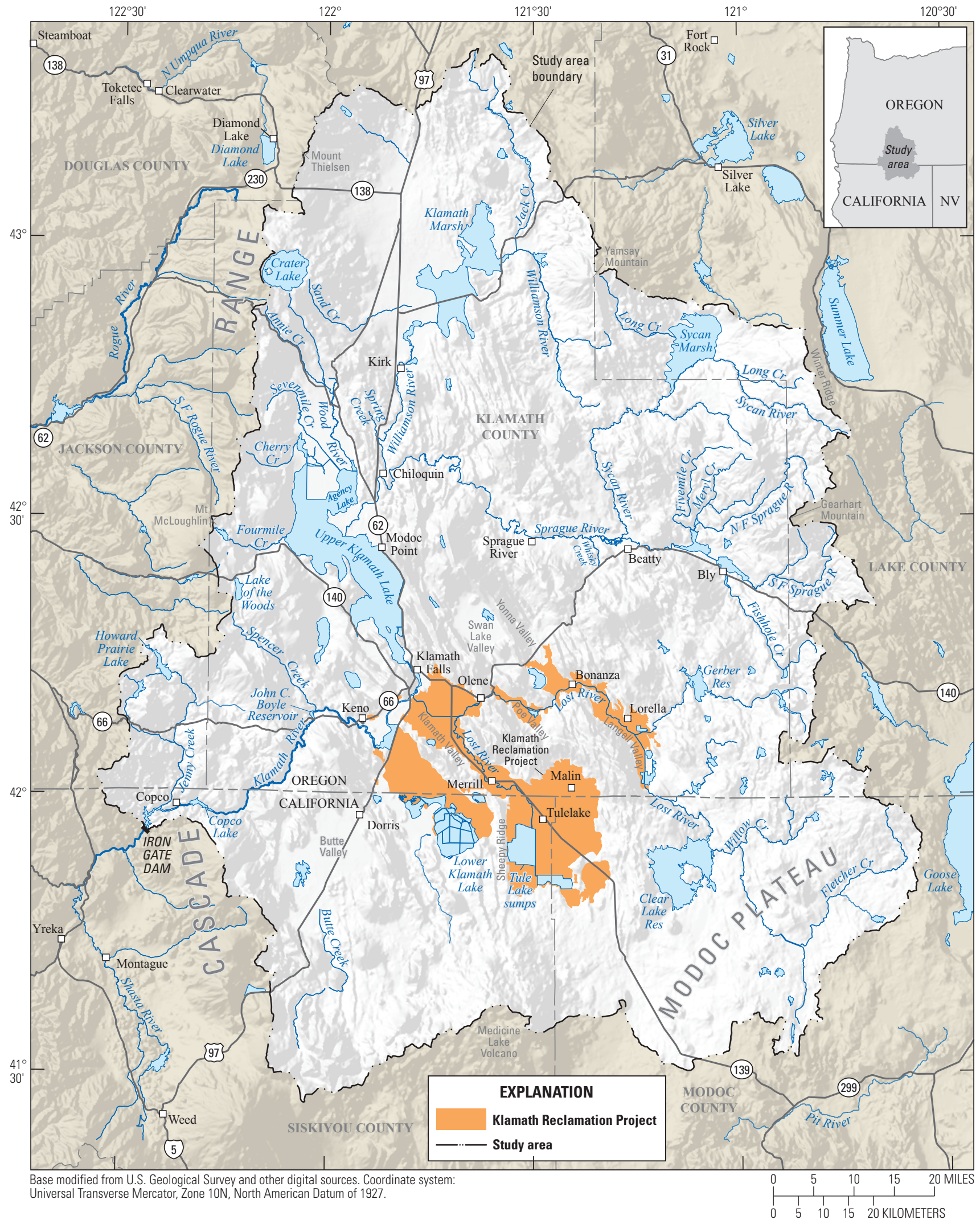

Figure 1. Locations of major geographic features, upper Klamath Basin, Oregon and California. 
long-term effects of groundwater-development decisions, the USGS, in cooperation with the Klamath Water and Power Agency (KWAPA) and the Oregon Water Resources Department (OWRD), began a follow-up study to develop an improved framework for testing and designing groundwatermanagement strategies for the Project. The improved framework uses techniques of groundwater simulation and optimization to enhance the utility of the simulation model by directly incorporating management goals and constraints into the modeling process. Of particular interest was the ability of the groundwater system to meet the increased groundwater demand of the Project foreseen under the KBRA while avoiding the adverse effects of groundwater development that concern resource-management agencies. This report provides an overview of the groundwater development issues in the upper Klamath Basin, describes the development of the combined simulation and optimization groundwatermanagement model, and provides applications of the model to evaluate alternative groundwater-management strategies. The report is intended to provide a basic understanding of the techniques of groundwater-management models and help water users and resource-management agencies understand the capacity for, and limitations of, supplemental groundwater use by the Project.

\section{Description of Study Area}

The upper Klamath Basin comprises the entire drainage basin upstream of Iron Gate Dam, including the internally drained Lost River and Butte Valley subbasins, and encompasses about $8,000 \mathrm{mi}^{2}$ (fig. 1). The demarcation between the upper and lower basins near Iron Gate Dam corresponds with the transition from a geologic terrane dominated by permeable volcanic rock to a terrane dominated by older rock with much lower permeability. Hence, there is negligible groundwater flow between the upper and lower basins.

The upper Klamath Basin occupies a broad, faulted volcanic plateau that spans the boundary between the Cascade Range and the Basin and Range geologic provinces. The basin is bounded by the volcanic arc of the Cascade Range on the west, the Deschutes River Basin to the north, internally drained basins to the east, and the Pit River Basin to the south. The elevation of the Cascade Range along the western margin ranges from 5,000 to 7,000 $\mathrm{ft}$ with major peaks exceeding $9,000 \mathrm{ft}$. The interior parts of the basin are dominated by northwest-trending, fault-bounded basins, typically several miles wide, with intervening uplands. Basin floors range in elevation from roughly 4,000 to $4,500 \mathrm{ft}$, and adjoining fault-block upland elevations range from 4,500 to more than 5,000 ft. The northern and eastern parts of the upper Klamath Basin consist of a volcanic plateau with numerous eruptive centers, some of which reach elevations exceeding $8,000 \mathrm{ft}$. The southeastern margin of the upper Klamath Basin consists of a broad, rugged, volcanic upland known as the Modoc Plateau, where the land-surface elevation ranges from 4,500 to 5,000 ft. The southern margin of the basin is marked by the broad shield of Medicine Lake Volcano, which reaches an elevation of 7,913 ft.

The upper Klamath Basin is semiarid because the Cascade Range intercepts much of the moisture from the eastward moving Pacific weather systems. Mean annual precipitation (1971-2000) ranges from 67 in. at Crater Lake National Park in the Cascade Range to 13.5 in. at the city of Klamath Falls, Oregon (Western Regional Climate Center, 2013). November through March precipitation accounts for 71 percent of the total at Crater Lake and 64 percent of the total at Klamath Falls. Most precipitation falls as snow at high elevations. The interior parts of the basin are dry during the spring and summer; mean monthly precipitation at Klamath Falls generally is less than 1 in. from April through October. Winters generally are cold, with January mean minimum and maximum temperatures at Klamath Falls of 21.9 and $39.9^{\circ} \mathrm{F}$, respectively. Summers, in contrast, are warm, with July mean minimum and maximum temperatures at Klamath Falls of 51.9 and $85.7^{\circ} \mathrm{F}$, respectively.

The 250-mi-long Klamath River begins at the outlet of Upper Klamath Lake. Major drainages upstream of the lake include the Williamson, Sprague, and Wood Rivers (fig. 1). The Williamson River drains much of the northern and eastern parts of the basin and flows directly into Upper Klamath Lake; the Sprague River, tributary to the Williamson, drains part of the eastern side of the basin. The Wood River and several smaller tributaries drain the valley north of the lake and the adjacent part of the Cascade Range. The Lost River system, also included in the upper Klamath Basin, is internally drained. It originates at Clear Lake in the southeastern part of the basin and originally terminated in Tule Lake. Tule Lake has now mostly been drained, and Lost River is now diverted just downstream of Olene through a channel to the Klamath River. Generally, little water from the Lost River drainage upstream of the diversion channel flows to the Tule Lake subbasin. The Tule Lake sumps, remnants of the original lake, now collect return flow from the Project (fig. 1). 
Upper Klamath Lake is the largest lake in the basin with a surface area between 100 and $140 \mathrm{mi}^{2}$ (including non-drained fringe wetlands) depending on stage (Hubbard, 1970; Snyder and Morace, 1997). Lake stage and outflow are controlled by a diversion dam at the lake outlet. About $1 \mathrm{mi}$ downstream of the diversion dam, the river flows into a 20-mi-long narrow reservoir behind a dam at Keno. John C. Boyle Reservoir and its dam are about $10 \mathrm{mi}$ downstream of Keno. Downstream of the John C. Boyle Reservoir, the river enters a narrow canyon and flows freely about $20 \mathrm{mi}$ to Copco Lake (a reservoir) and immediately downstream of that, Iron Gate Reservoir. Iron Gate Dam, which impounds Iron Gate Reservoir, marks the downstream boundary of the upper Klamath Basin. No impoundments are on the Klamath River downstream of Iron Gate Dam.

The surface-water hydrology of the upper Klamath Basin has been extensively modified by drainage of lakes and wetlands for agriculture, and the diversion and routing of water for irrigation. Prior to development, the Tule Lake and Lower Klamath Lake subbasins contained large lakes fringed by extensive wetlands. At high stage (about 4,060 ft elevation) Tule Lake covered an area exceeding $150 \mathrm{mi}^{2}$ (La Rue, 1922). Historical accounts indicate that at high stage Tule Lake drained into the lava flows along the southern margin. Because of subsurface drainage, Tule Lake was not an evaporative sink and was not saline (La Rue, 1922). Since 1942, excess water from the Tule Lake sumps has been pumped using a tunnel through Sheepy Ridge west into the Lower Klamath Lake subbasin. The Lower Klamath Lake subbasin once held a large lake-marsh complex that covered about 88,000 acres, about 58,000 acres of which were marginal wetlands with the remaining 30,000 acres open water (La Rue, 1922). Lower Klamath Lake was connected to the Klamath River through a channel known as the Klamath Strait, and probably through the expansive wetland that separated the lake from the river elsewhere. In the early 1900s, an earth-fill railroad bed was constructed across the northwestern margin of the Lower Klamath Lake subbasin, cutting off flow between the lake and river except at the Klamath Strait. In 1917, the control structure built into this impoundment at the Klamath Strait was closed, cutting off flow to the lake. As a result, Lower Klamath Lake is now largely drained, with much of the former lakebed and fringe wetlands under cultivation. Areas of open water remain in the Lower Klamath Wildlife Refuge in the southern part of the subbasin in California.

About 500,000 acres of agricultural land are irrigated in the upper Klamath Basin, roughly 190,000 of which are included in the Project (Carlson and Todd, 2003; Natural Resources Conservation Service, 2004). This total does not include wildlife refuge areas within the Project.
Irrigation water comes from various sources in the upper Klamath Basin. Upstream of Upper Klamath Lake, in the Williamson, Sprague, and Wood River drainages, private (off-Project) irrigation water primarily comes from diversion of surface water from the main stem streams or tributaries. A smaller amount of irrigation water is pumped from wells, particularly in the Sprague River Valley and Klamath Marsh areas (ig. 1). In the Langell and Yonna Valleys of the upper Lost River subbasin, irrigation water comes from Clear Lake and Gerber Reservoirs. Irrigators use groundwater and some surface water in Swan Lake Valley. Groundwater is used for irrigation in areas not served by irrigation districts and to supplement surface-water supplies throughout the area.

Upper Klamath Lake is the largest single source of irrigation water in the basin. Water is stored in and diverted from the lake to irrigate the Project, which encompasses land south of Klamath Falls, including the Klamath Valley, Poe Valley (in the Lost River subbasin), and the Lower Klamath and Tule Lake subbasins. Water diverted from the Klamath River several miles downstream of the lake also is used for irrigation and refuges in the Lower Klamath Lake subbasin. Return flow from the Lower Klamath Lake subbasin is routed through a series of pumping stations back to the Klamath River.

A certain amount of groundwater is used for irrigation on land surrounding the Project upslope of the major canals. Primary areas of groundwater use surrounding the Project include the southern end of the Klamath Hills, parts of the Klamath Valley, and the northern and eastern margins of the Tule Lake subbasin (fig. 1). Some groundwater traditionally has been used for supplemental irrigation in the Project area.

\section{Previous Studies}

The modeling work described in this report builds on efforts dating back several decades. Newcomb and Hart (1958) described the geologic framework of the groundwater system, inventoried wells, and quantified groundwater discharge to major springs and streams in the basin. They also demonstrated the relation between spring discharge and long-term precipitation patterns. At the time of their study, total groundwater pumping in the Oregon part of the basin was about 30,000 acre-ft. Leonard and Harris (1974) refined the assessment of groundwater in the upper basin, inventoried additional wells, and quantified geographic distribution of groundwater discharge along the Sprague and Lost Rivers. At the time of the Leonard and Harris study, total groundwater pumping in the Oregon part of the basin was about 61,000 acre-ft. Both these early studies were restricted to Oregon. 
One of the first detailed groundwater studies in the California part of the upper Klamath Basin was by Wood (1960), who mapped the geology and described the groundwater hydrology of the Butte Valley area. About 21,000 acre-ft of groundwater was pumped for irrigation in Butte valley in 1953. Groundwater continues to be a major source of irrigation water in Butte Valley. Hotchkiss (1968) described the geologic and hydrologic conditions in and around Lava Beds National Monument adjacent to the Project. The primary purpose of the Hotchkiss study was to identify water sources for the Monument. The California Department of Water Resources (CDWR; 1998) published an investigation into well interference in Butte Valley, which includes results of aquifer tests and estimates of aquifer hydraulic characteristics. None of these early studies focused specifically on the area of the Project.

In response to a marked increase in groundwater pumping in 2001, California Department of Water Resources (2003) investigated the hydrogeology and groundwater conditions in the Tule Lake subbasin. That report includes an inventory of wells and pumping in the area, a description of the hydrogeology, hydrographs of several wells, a map of the top of bedrock beneath the basin, and maps of the water-table surface at different times.

The Oregon Water Resources Department (OWRD) conducted an investigation of groundwater conditions in the upper Lost River area in response to increased groundwater demand and the potential for interference with major springs discharging to the river (Grondin, 2004). For that study, OWRD inventoried and measured water levels in hundreds of wells, measured groundwater discharge to the upper Lost River, described the geologic framework, and reported results of several aquifer tests conducted in the area. Grondin (2004) includes a comprehensive dataset, detailed analysis, and includes maps of the top of bedrock and the water-table elevation in the area.

The present (2013) understanding of groundwaterflow directions, the influence of climate, and the effects of pumping, is the result of many decades of well inventory and water level monitoring by multiple agencies. CDWR has collected extensive data in the California part of the basin, particularly the Butte Valley and Tule Lake areas. Several long-term monitoring wells operated by OWRD in the upper Klamath Basin have records extending back to the 1960s, and extensive data from the upper Lost River subbasin and around the Oregon parts of the Project. The USGS has collected quarterly water-level data on 50-70 wells since the late 1990s, focusing primarily on upland areas to characterize climatic influences (Gannett and others, 2007).
Building on these decades of data collection and interpretive studies, Gannett and others (2007) described and synthesized the groundwater hydrology of the entire upper Klamath Basin and developed a regional water budget, a map and table that describe groundwater discharge to streams, and a regional water-table map. That effort formed the basis for development of the regional groundwater-flow model and coupled the groundwater-management model (Gannett and others, 2012) used for the simulations described in this report.

\section{Groundwater-Simulation Model}

The groundwater hydrology and groundwater-simulation model of the upper Klamath Basin are described in detail in Gannett and others $(2007,2012)$. The discussion in this section is largely from those reports.

The upper Klamath Basin has a substantial regional groundwater system that is used for irrigation in certain areas of the basin and supports aquatic habitat for endangered species. Tertiary and Quaternary volcanic rocks and sedimentary deposits underlie the region and compose eight regional-scale hydrogeologic units. The late Tertiary and Quaternary volcanic rocks in the basin are generally permeable and comprise a system of interconnected aquifers that are interbedded with fine-grained lake deposits and basin-filling sediments. The regional groundwater system is underlain and bounded on the east and west by older, less permeable Tertiary rocks that act as barriers to groundwater flow. Boundaries between the regional groundwater system and the basins to the north and south are defined by surfacewater divides.

Groundwater originates as recharge in the Cascade Range and upland areas in the basin interior and eastern margins, and flows toward stream valleys and interior subbasins. Groundwater discharges to streams throughout the basin, with large amounts of groundwater discharging to streams in the Wood River subbasin, the lower Williamson River, and along the margins of the Cascade Range. Groundwater also discharges directly to Upper Klamath Lake, and a substantial amount of the total inflow to the lake originates as groundwater discharge to streams and spring complexes within roughly $10 \mathrm{mi}$ of the lake. Groundwater discharge areas also are in the eastern part of the basin (for example, in the upper Williamson, Sprague River, and Lost River subbasins).

The groundwater system in the upper Klamath Basin responds to external stresses, such as climate cycles and groundwater pumping. Basin-wide, decadal-scale climate cycles are the largest factors controlling groundwater-level 
and discharge fluctuations. Water-table fluctuations of $5 \mathrm{ft}$ or more are common throughout the basin as a result of decadalscale climate cycles, and groundwater discharge varies by a factor of two or more as a result of wet and dry periods. The response of the groundwater system to pumping generally is largest in areas with irrigation pumping. The effects of recent increases in pumping by the Project are apparent in areas within and adjacent to the Project where the water table has declined more than $30 \mathrm{ft}$ over areas covering tens of square miles (Gall, 2011). The effects of pumping on streams and springs, however, generally are diffuse and difficult to measure.

The groundwater-simulation model of the upper Klamath Basin was developed using the USGS MODFLOW groundwater-modeling code (McDonald and Harbaugh, 1988). The simulation model has 285 rows, 210 columns, and 3 layers; model cells have dimensions of 2,500 by $2,500 \mathrm{ft}$ and model layers have thicknesses ranging from 5 to $3,600 \mathrm{ft}$. The hydraulic characteristics of the regional groundwater system are defined with 18 model-parameter zones that represent large-scale geologic conditions. Boundaries with adjacent basins and underlying low permeability Tertiary strata are defined as zero-flux boundaries in most areas. Head-dependent boundaries define streams, lakes and reservoirs, agricultural drains, evapotranspiration in areas of shallow groundwater, and boundaries with adjacent basins in select areas.

Groundwater recharge and pumping at more than 1,000 wells are simulated as time-varying fluxes defined for quarterly stress periods. The groundwater model was calibrated to transient conditions from 1989 to 2004 using groundwaterlevel observations at 663 wells and groundwater-discharge measurements for 10 stream reaches or spring complexes. The calibrated groundwater model simulates climate-driven decadal variations in groundwater levels and discharge in the upper Klamath Basin, as well as the observed seasonal and year-to-year groundwater-level fluctuations in response to groundwater pumping.

The groundwater-simulation model has the capability to calculate the effects of alternative pumping strategies on groundwater levels and discharge to streams, lakes, and drains. Example model simulations that show the various responses of groundwater levels and discharge to pumping depending on the pumping location are shown in Gannett and others (2012). Simulations show that the groundwater-discharge features most affected by pumping in the area of the Project are agricultural drains, and effects on other surface-water features are relatively small. When coupled with optimization, the capability of the groundwater-simulation model is enhanced. The coupled simulation-optimization model can evaluate the effects of a wide range of potential pumping scenarios on groundwater levels and discharge, and identify the best pumping strategy to meet the goals of water users and resource-management agencies.

\section{Groundwater-Management Strategies}

Managing the limited water resources of the upper Klamath Basin is a multi-faceted problem where the consumptive uses of agriculture and instream needs of aquatic wildlife must be balanced. In 2001, actions intended to protect habitat for endangered fishes resulted in the curtailment of surface-water deliveries to the Project. In the years since, Endangered Species Act biological opinions have required the Bureau of Reclamation (Reclamation) to maintain specified levels in Upper Klamath Lake to protect habitat for Lost River and shortnose suckers while simultaneously providing flows in the Klamath River downstream of Iron Gate Dam to maintain habitat for coho salmon. This shift in water-management priorities resulted in substantial reductions in surface-water diversions to the Project in 2001 and 2010, and increases the likelihood of Project water shortages in the future.

In response to changing water-management priorities, stakeholders in the basin developed the KBRA, a framework for water-resources management designed to restore aquatic habitat and provide reliable water supplies for irrigation (Klamath Basin Restoration Agreement, 2010). Although the KBRA provides for predictable surface-water diversions to the Project, those water supplies will be diminished in dry years, with irrigation-diversion deficits as much as about 100,000 acre-ft in the driest years. Surface water will not be able to meet Project irrigation demands in every year and groundwater is a potential alternative irrigation supply (Klamath Basin Restoration Agreement, 2010).

\section{Groundwater Use in the Upper Klamath Basin}

Groundwater use in the upper Klamath Basin is primarily for agriculture and public supply. Prior to 2001, the estimated groundwater withdrawals in the basin totaled about 160,000 acre-ft, with about 10,000 acre-ft pumped for public supply and about 150,000 acre-ft pumped for irrigation (Gannett and others, 2007). Irrigation withdrawals in the area of the Project totaled about 29,000 acre-ft or 19 percent of the total irrigation withdrawals in the basin. Since 2001, groundwater use in the upper Klamath Basin has increased considerably, mostly due to programs funded by Reclamation and KWAPA and designed to supplement the reduced surfacewater supplies for the Project. The volumes of groundwater purchased by these programs are summarized in figure 2 . During 2001-07, Reclamation's Groundwater Acquisition and Pilot Water Bank programs annually pumped as much as 66,000 acre- $\mathrm{ft}$ to supplement the reduced surface-water diversions to the Project. This represents a maximum of 45 percent increase in basin-wide irrigation withdrawals when compared to pre-2001 pumping amounts. In 2010, Project supplemental groundwater pumping was funded by the KWAPA Water Users Mitigation Program and totaled 
about 101,000 acre-ft, a 67 percent increase in pre-2001 irrigation withdrawals, and roughly a four-fold increase in Project-area irrigation pumping (MBK Engineers and others, 2012a; Gall, 2011; Klamath Water Users Association, 2011). Pumping amounts shown in figure 2 represent only the amounts purchased by Reclamation and KWAPA. The total annual amounts of groundwater pumped from 2001 to 2004 to supplement Project water supplies were as much as 33,000 acre-ft higher than the amounts shown in figure 2 (McFarland and others, 2005; Gannett and others, 2007).

Increased supplemental pumping for the Project during 2001-07 resulted in water-level declines of 10-15 ft over much of the Project, and hydrographs indicate water levels reached a new equilibrium with the regional groundwater system. The sharp increase in pumping in 2010, however, caused some of the largest seasonal water-level declines and lowest water levels on record, with persistent declines of 3-7 ft in some areas compared to pre-2010 groundwater levels (Gall, 2011). The effects of Project groundwater pumping are not limited to Project water users. The effects can potentially extend off-Project to surface-water features and off-Project

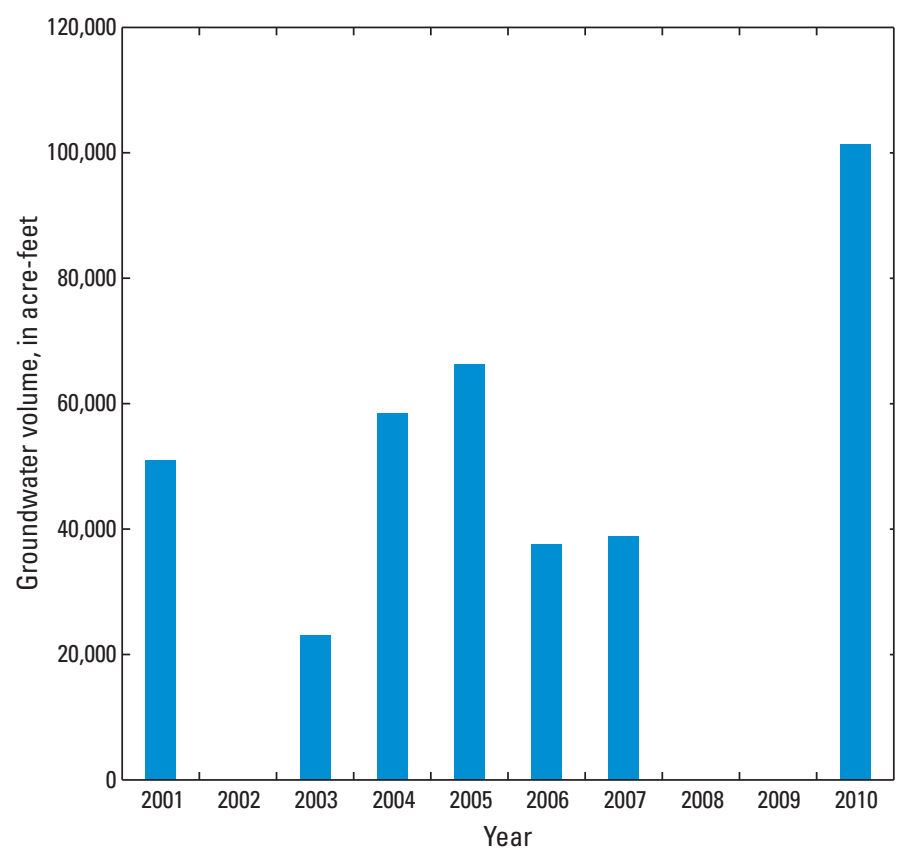

Figure 2. Supplemental groundwater volume purchased for the Bureau of Reclamation Klamath Irrigation Project, upper Klamath Basin, Oregon and California, 2001-10. Groundwater was not purchased in 2002, 2008, and 2009. irrigation, domestic, and municipal wells. In 2010 and 2011, KWAPA funded the Domestic and Municipal Well Mitigation Program to improve domestic and municipal supply wells adversely affected by on-Project pumping. Financial assistance was provided to well owners for the purpose of lowering pumps, deepening existing wells, and drilling new wells (Gall, 2011; Klamath Water Users Association, 2011).

\section{Hypothetical Groundwater Demand under the Klamath Basin Restoration Agreement}

Water use by the Project varies primarily as a function of climate, with increased irrigation demand in dry years. For this study, alternative groundwater-management strategies were simulated for 1970-2004, a 35-year management period that includes multiple wet and dry periods. The groundwater demand of the Project was defined as the difference between the demand for irrigation and the amount of surface water available for diversion to the Project. One method for estimating irrigation demand is to define the demand based on historical irrigation diversions. Prior to 2001, annual irrigation diversions from Upper Klamath Lake ranged from about 310,000 to about 430,000 acre-ft, with the highest diversions occurring during the extended drought period from 1987 to 1994 (McFarland and others, 2005; MBK Engineers and others, 2012b). Since 2001, however, Endangered Species Act restrictions have limited surface-water diversions in dry years. As a result, surface-water deliveries to the Project in 2001, 2003, and 2004 did not represent actual Project irrigation demand. Moreover, historical irrigation diversions may not reflect changes to Project operations, such as changes to cropping patterns and irrigation practices. An alternative method for estimating irrigation demand during 1970-2004 is based on Reclamation's Klamath-Project simulation model, which estimates irrigation demand within the Project based on present-day cropping patterns, irrigation needs, and historical hydrologic conditions (MBK Engineers and others, 2012b). The approach taken in this study was to estimate the Project annual irrigation demand for each year during 1970-2004 as the larger of the historical irrigation diversion and the simulated irrigation demand. This approach also was used by KWAPA to develop the on-Project Plan, a water-use plan for the Project that is an integral component of the KBRA (Klamath Basin Restoration Agreement, 2010, section 15).

In contrast to irrigation demand, the diversions allowed under the KBRA will be smallest during dry years when inflows to Upper Klamath Lake tend to be smaller than average. The diversions allowed under the KBRA Phase-1 
allotment schedule are calculated as a function of projected inflows to Upper Klamath Lake during the April-October irrigation season and vary from 330,000 acre-ft in low-inflow years to 385,000 acre-ft in high-inflow years (Klamath Basin Restoration Agreement, 2010, appendix E-1). This relation of increasing Project irrigation demand with decreasing KBRA surface-water allotment creates a scenario in which the highest groundwater demand is expected in the driest years. This relation is shown in figure $3 A$, which shows the estimated irrigation demand with the hypothetical diversions that would be allowed under the KBRA. The differences between surface-water demands and the diversion amounts allowed under the KBRA define the hypothetical groundwater demand function that is included as constraints in the groundwater-management model. The hypothetical Project groundwater demand is shown in figure $3 B$ and ranges from zero for years in which the calculated KBRA surface-water allotment equals or exceeds the predicted irrigation demand to about 102,000 acre-ft in the drought year of 1991. The 35 -year groundwater-demand schedule has 22 years with nonzero groundwater demand. Of those 22 years, 6 years have demands less than 20,000 acre-ft, 8 years have demands of $20,000-60,000$ acre-ft, and 8 years have groundwater demands that exceed 60,000 acre-ft (fig. $3 B$ ). The extended drought period from 1987 to 1994 includes 6 of the 8 years with groundwater demand greater than 60,000 acre-ft.

The groundwater demand schedule shown in figure $3 B$ assumes that irrigation-demand deficits under the Klamath Basin Restoration Agreement will be met, to the extent possible, using groundwater. The KBRA proposes additional measures to improve water supplies and reduce irrigation demand, such as demand management, efficiency measures, new surface-water storage, and land and water acquisitions. Since 2001, however, Reclamation and KWAPA have relied primarily on a combination of groundwater pumping to supplement surface-water supplies and demand management (in the form of temporary land idling) to reduce irrigation demand. In 2010, KWAPA purchased approximately 101,000 acre- $\mathrm{ft}$ of groundwater at an average cost of about 25 dollars per acre-foot. At the same time, KWAPA accepted bids to idle approximately 36,000 acres of farmland within the Project at an estimated cost of about 85 dollars per acrefoot of reduced irrigation-water demand (Klamath Water Users Association, 2011). The cost difference suggests that groundwater substitution will be an important means to bridge the periods of reduced surface-water diversions foreseen under the KBRA.
Groundwater is expected to be an important supplemental water supply for Project irrigators. If the marked increase in pumping since 2001 is sustained, a new state of dynamic equilibrium eventually will be reached, with unknown effects to groundwater and surface-water resources throughout the basin. As a result, groundwater users and resourcemanagement agencies in the upper Klamath Basin need methods to identify groundwater-management strategies that meet the double goals of increased groundwater production and resource protection.

\section{Simulation-Optimization Model}

Groundwater-development alternatives for the upper Klamath Basin were evaluated with the aid of a coupled simulation and optimization groundwater-management model. The simulation model described in Gannett and others (2012) was used to estimate the spatial and temporal distribution of pumping related drawdowns; the effects of pumping on streams, springs, and lakes critical to aquatic wildlife; and the effects on agricultural drains that provide irrigation water to farmers in the Project and also are a source of water for national wildlife refuges within the Project boundaries. The simulation model was coupled with an optimization algorithm to form a groundwater-management model that was used to identify solutions for improving groundwater use in the Project. The groundwater-management model provides a tool for efficiently processing and ranking groundwatermanagement alternatives and identifying solutions that best meet the goals of water users and resource-management agencies. Literature reviews of simulation-optimization research are available in Gorelick (1983), Yeh (1992), Wagner (1995), and Ahlfeld and Mulligan (2000). Example applications of the simulation-optimization approach that include groundwater-surface-water interactions include Barlow and Dickerman (2001), DeSimone and others (2002), Granato and Barlow (2004), and Gannett and others (2012).

A groundwater-management model for the upper Klamath Basin was developed and tested in a previous study (Gannett and others, 2012). In that study, the goal was to determine the maximum annual pumping amount that could be sustained over a 20 -year period; the optimal groundwaterpumping strategies were identified using a dynamic steadystate groundwater-simulation model that was based on average historical climate conditions. The simulation model used in that study did not include off-Project supplemental pumping and the simulation-optimization model did not explicitly 

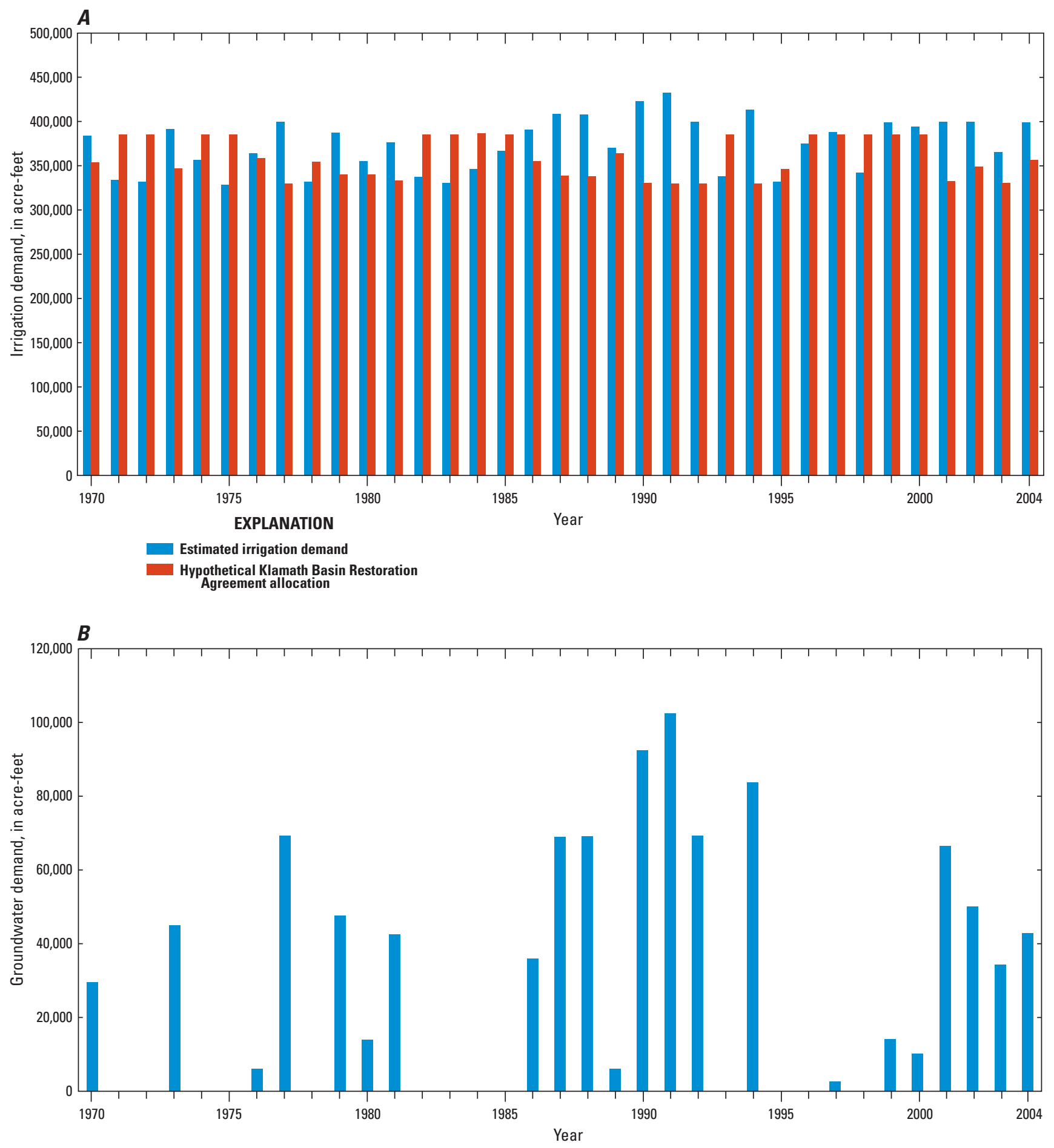

Figure 3. (A) Estimated irrigation demand from Upper Klamath Lake to the Bureau of Reclamation Klamath Irrigation Project (Project) and hypothetical irrigation deliveries based on limits defined in the Klamath Basin Restoration Agreement, and (B) hypothetical Project groundwater demand, upper Klamath Basin, Oregon and California, 1970-2004. 
account for the Project groundwater demand as foreseen under the KBRA. This report describes the development and application of an enhanced groundwater-management model that incorporates variable hydrologic conditions from the recent historical record. The simulation model used in this study also incorporates time-varying background supplemental pumping that accounts for increased groundwater withdrawal by off-Project irrigators during drought periods. Finally, a groundwater-demand function (fig. $3 B$ ) derived from the KBRA surface-water-allotment formula is incorporated in the groundwater-management model to account for the Project time-varying groundwater needs.

\section{Potential Adverse Effects of Groundwater Development}

The fundamental goal of the enhanced upper Klamath Basin groundwater-management model is to determine the spatial and temporal distribution of pumping that, to the extent possible, meets the hypothetical Project groundwater demand (fig. 3B) while avoiding adverse effects to groundwater and surface-water resources. These effects include the link between groundwater pumping and groundwater discharge that supports aquatic habitat, the effect of increased pumping on water levels throughout the Project and adjacent areas, and the effect of groundwater withdrawal on irrigation return flows that are essential to Project operations.

Groundwater discharge provides a substantial proportion of streamflow in the upper Klamath Basin and is particularly important during the April-October irrigation season when precipitation is low and there are competing agriculture and ecological water demands. The KBRA provides measures for defining and limiting the adverse effects of groundwater pumping on streams and springs in the basin. The KBRA defines adverse effects as a 6 percent or greater reduction in groundwater discharge to springs associated with Upper Klamath Lake, the Wood River and its tributaries, Spring Creek and the lower Williamson River, and the Klamath River and its tributaries (fig. 1). The KBRA further defines the measure of pumping related effects on surface-water resources to include only the effects resulting from groundwater use within the Project. That is, all off-Project pumping in the basin is considered part of the baseline conditions against which the effects of on-Project pumping will be measured (Klamath Basin Restoration Agreement, 2010, section 15).

The groundwater-management model also must consider the effects of groundwater development on existing groundwater users. The OWRD controls new groundwater appropriations and can regulate pumping to protect senior water-right holders (Oregon Water Resources Department, 2011). Since 2000, OWRD has been applying water-leveldecline limits to new groundwater-right permits in the upper
Klamath Basin. The permit conditions constrain drawdown at various time scales. Seasonal drawdown constraints limit the water-level declines that develop during the irrigation season, year-to-year drawdown constraints limit the drawdown remaining at the beginning of the irrigation season because of the previous year withdrawal, and long-term drawdown constraints limit the water-level declines that accumulate over a 10-year period. Groundwater development currently (2013) is not regulated in the California part of the upper Klamath Basin; therefore, initial applications of the groundwatermanagement model apply OWRD drawdown limits in the Oregon and California parts of the model. Sensitivity analysis is used to test the effect of alternative drawdown limits.

Finally, the groundwater-management model must evaluate the reductions in groundwater discharge to the Project drain system caused by groundwater pumping. Studies of groundwater use within irrigated agricultural areas in the western United States have shown that substantial amounts of pumped groundwater can originate as irrigation water that is captured by pumping wells (Reilly and others, 2008). In the Project, irrigation return flows are recirculated through the drain system and can be a significant water supply for downslope irrigators. Irrigation return flows also are used to maintain permanent and seasonal wetlands in the Tule Lake and Lower Klamath National Wildlife Refuges (Burt and Freeman, 2003; Risley and Gannett, 2006). Any groundwater discharge diverted from the drain system by pumping will reduce the amount of water available for irrigation and delivery to the refuges. The groundwater-management model is designed to evaluate and limit the effects of groundwater pumping on the Project drain system. The analyses described in this report were limited by the lack of information available to define the Project demand for irrigation return flows. Therefore, the groundwater-management model was solved for a varied set of drain flow-reduction limits to provide information on the sensitivity of management-model results.

\section{Formulation and Solution of the Groundwater- Management Model, 1970-2004}

The groundwater-simulation model described in Gannett and others (2012) was coupled with an optimization algorithm to identify solutions that improve groundwater production for the Klamath Project. The manageable components of the optimization model are the time-varying pumping rates at 117 wells distributed throughout the Project (fig. 4A). Constraint equations set limits on drawdowns at various time scales, reductions in groundwater discharge that support aquatic habitat, reductions in groundwater discharge to the Project drain system, annual groundwater-pumping goals, and the maximum pumping rate at each well. 


\section{Alternative Groundwater-Management Strategies, Bureau of Reclamation Klamath Project, Oregon and California}

The optimization problem is formulated as a linear programming problem:

$$
\operatorname{Maximize} \sum_{i=1}^{N W} \sum_{j=3}^{4} \sum_{k=1}^{N Y} Q w_{i, j, k}
$$

subject to:

$$
\begin{aligned}
& D D_{\text {seas }, n, 3, k}=h_{n, 2, k}-h_{n, 3, k} \leq D D_{\text {seas,max }} n=1, n d d \\
& D D_{\text {seas }, n, 4, k}=h_{n, 2, k}-h_{n, 4, k} \leq D D_{\text {seas,max }} n=1, n d d \\
& D D_{y 2 y, n, k}=h_{n, 2, k}-h_{n, 2, k+1} \leq D D_{y 2 y, \text { max }} n=1, n d d \\
& D D_{10 y r, n, k}=h_{n, 2, k}-h_{n, 2, k+10} \leq D D_{10 y r, \text { max }} n=1, n d d
\end{aligned}
$$

$$
h_{n, 2, k} \geq h_{n, \min } n=1, n d d
$$

$$
Q S R_{n, j, k}=q s r_{n, j, k, b a s e}-q s r_{n, j, k, \text { man }} \leq Q S R_{n, j, k, \text { max }} n=1, n s r
$$

$$
Q L R_{j, k}=q l r_{j, k, \text { base }}-q l r_{j, k, \text { man }} \leq Q L R_{j, k, \max }
$$

$$
Q D R_{j, k}=q d r_{j, k, b a s e}-q d r_{j, k, \text { man }} \leq Q D R_{j, k, \max }
$$

$$
\begin{gathered}
\sum_{i=1}^{N W} \sum_{j=3}^{4} Q w_{i, j, k} \leq Q D E M_{k} \\
0 \leq Q w_{i, j, k} \leq Q w_{i, \max }
\end{gathered}
$$

where:

$Q w_{i, j, k} \quad$ is the pumping rate at managed well $i$ in quarter $j$ of water year $k$;

$N Y \quad$ is the number of years in the management horizon and equals 35 ;

$N W \quad$ is the number of decision wells and equals 35 (note that well aggregation is used to reduce the number of decision variables);

$i \quad$ is the well number;

$j \quad$ is the water year quarter, 1-4, with water year quarters 3 and 4 comprising the April to October irrigation season;

$k \quad$ is the year, with $\mathrm{k}=1$ corresponding to water year 1970 ;

$D D_{\text {seas }, n, 3, k}$ is the seasonal drawdown at constraint location $n$ at the end of quarter 3 (mid-point of irrigation season) in water year $k$;

$h_{n, 2, k} \quad$ is the head at control location $n$ at the end of quarter 2 (beginning of irrigation season) in water year $k$;

$h_{n, 3, k}$ is the head at control location $n$ at the end of quarter 3 (mid-point of irrigation season) in water year $k$;

$D D_{\text {seas, } \max }$ is the upper bound on seasonal drawdown;

$D D_{\text {seas }, n, 4, k}$ is the seasonal drawdown at constraint location $n$ at the end of quarter 4 (end of irrigation season) in water year $k$;

$h_{n, 4, k} \quad$ is the head at control location $n$ at the end of quarter 4 (end of irrigation season) in water year $k$;

$D D_{y 2 y, n, k} \quad$ is the year-to-year drawdown at constraint location $n$ in water year $k$;

$D D$

$D D_{10 y, n, k}$

DD $10 y$, max is the upper bound on year-to-year drawdown;

is the decadal drawdown at constraint location $n$ in water year $k$; is the upper bound on decadal drawdown; is the lower bound on head at control location $n$; is the reduction in groundwater discharge to stream reach $n$ in quarter $j$ of water year $k$;

is the groundwater discharge to stream reach $n$ in quarter $j$ of water year $k$ for baseline conditions with no Project pumping;

$q s r_{n, j, k, \text { man }}$ is the groundwater discharge to stream reach $n$ in quarter $j$ of water year $k$ for managed conditions with optimized Project pumping;

$Q S R_{n, j, k, \max }$ is the maximum allowable reduction in groundwater discharge to stream reach $n$ in quarter $j$ of water year $k$, $Q L R_{j, k}$ is the reduction in groundwater discharge to Upper Klamath Lake in quarter $j$ of water year $k$;

$q l r_{j, k, b a s e}$ is the groundwater discharge to Upper Klamath Lake in quarter $j$ of water year $k$ for baseline conditions with no Project pumping;

$q l r_{n, j, k, \text { man }}$ is the groundwater discharge to Upper Klamath Lake in quarter $j$ of water year $k$ for managed conditions with optimized Project pumping;

$Q L R_{j, k, \max }$ is the maximum allowable reduction in groundwater discharge to Upper Klamath Lake in quarter $j$ of water year $k$,

$Q D R_{j, k} \quad$ is the reduction in groundwater discharge to Project drains in quarter $j$ of water year $k$; 


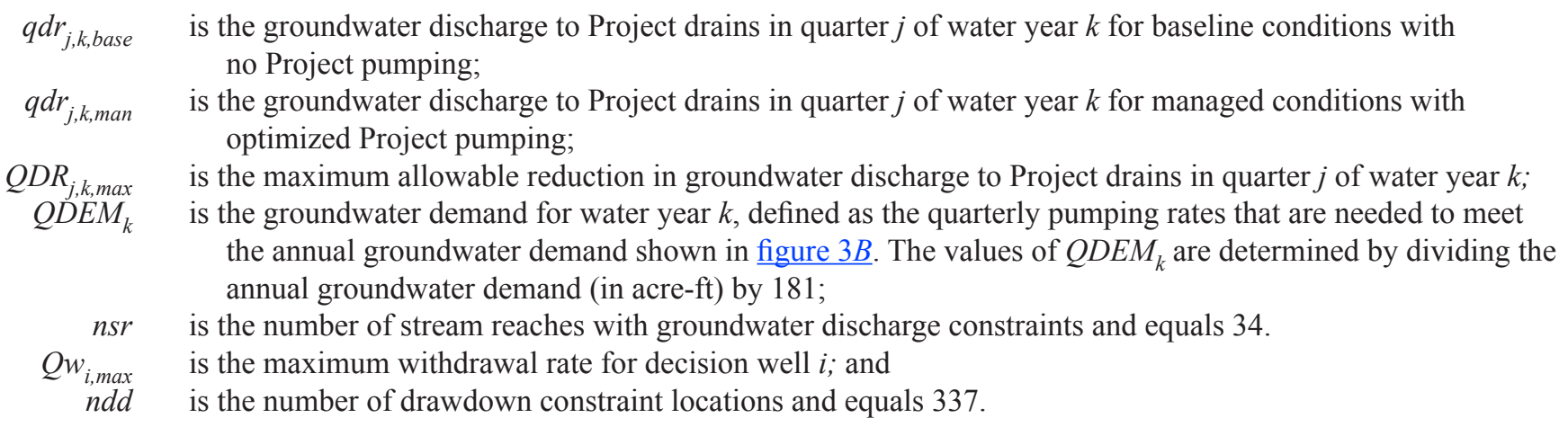

The objective function (equation 1) sums the quarterly pumping at each managed well during water-year (the 12-month period from October 1, for any given year, through September 30 of the following year) quarters 3 and 4 , which comprise the irrigation season, for each year of the 35 -year management period. The managed wells used in the optimization model are shown in figure $4 A$ and represent the wells used in Reclamation's Groundwater Acquisition and Pilot Water Bank programs and KWAPA's Water Users Mitigation Program. The optimization model calculates the pumping rates for the 117 managed wells shown in figure 4A; all other wells in the model are considered to be background stresses that contribute to the total stress acting on the groundwater system, but do not change from one simulation to the next.

In this study, aggregated pumping rates are used to define the decision variables of the groundwater-management model. Each decision variable, $Q w_{i, j, k}$, was defined as a subset of the managed wells shown in figure $4 A$ and represents the aggregated quarterly withdrawal from a localized area of the Project. For each aggregated decision variable, the optimization model determines a single value that is distributed among the wells comprising that decision variable and that is apportioned according to the pumping capacity for each well. The analyses described in this report include 35 aggregated decision wells formed by the 117 individual wells shown in figure $4 A$; the number of individual wells in each aggregated well group ranges from one to six, with an average of about three wells per group. The groundwatermanagement model calculates $3 \mathrm{rd}$ and 4 th quarter pumping rates (in units of cubic feet per second) for the 35 aggregated decision wells in each of the 22 years with non-zero groundwater demand, for 1,540 decision variables. Multiplying the quarterly groundwater-pumping rates by 181 defines the volume of groundwater pumped in units of acre-feet. Pumping volumes are used to describe the results of the groundwater-management model in the remainder of the report.

Well aggregation reduces the number of decision variables in the optimization model, which reduces the computational effort required to solve each optimization problem. The well-aggregation method, however, also reduces the flexibility of the management solution by limiting the manner in which well rates within an aggregated well group can vary relative to each other. The effect of well aggregation is a suboptimal solution when compared to the solution obtained without aggregation. The amount by which the well-aggregation method underestimates the optimal pumping can be determined only by solving the nonaggregated optimization model, which will be different for every formulation of the optimization problem. An example of simulation-optimization modeling with well aggregation is available in Barlow and others (1996).

Equations 2-11 define the constraints of the optimization model; that is, the measures used to define the success or failure of alternative groundwater-management plans. Groundwater withdrawal can have short- and long-term effects on water levels. The optimization model includes constraints on drawdown at 337 control locations shown in figure $4 B$. Drawdown controls were applied at the 117 model cells that contain managed wells along with 220 model cells that contain off-Project pumping wells within $6 \mathrm{mi}$ (12 model cells) of a managed well. Four types of drawdown constraints were applied at each control location: (1) seasonal drawdown constraints (equations 2 and $\underline{3}$ ) were defined to limit the lowering of water levels during the irrigation season, (2) year-to-year drawdown constraints (equation 4) were defined to limit the residual drawdown remaining at the beginning of the irrigation season because of the previous year withdrawal, (3) a drawdown constraint (equation 5) was included to limit the long-term drawdown simulated over a decade, and (4) a constraint was included to impose a maximum drawdown by defining the minimum allowable head at each location (equation 6). The seasonal, year-to-year, and decadal drawdown limits, $D D_{\text {seas, } \max }, D D_{y 2 y \text {, } \max }$, and $D D_{10 y, \text { max }}$, were set to 25,3 , and $25 \mathrm{ft}$, respectively, in the base-case optimization model, as required by Oregon water law (Oregon Water Resources Department, 2011). At each drawdown constraint location, the minimum allowable head, $h_{n, \text { min }}$, was set to $25 \mathrm{ft}$ below the simulated 2001 pre-irrigation-season water level. A sensitivity analysis was done to assess the effect of varying the seasonal, year-to-year, and 10-year drawdown limits. 


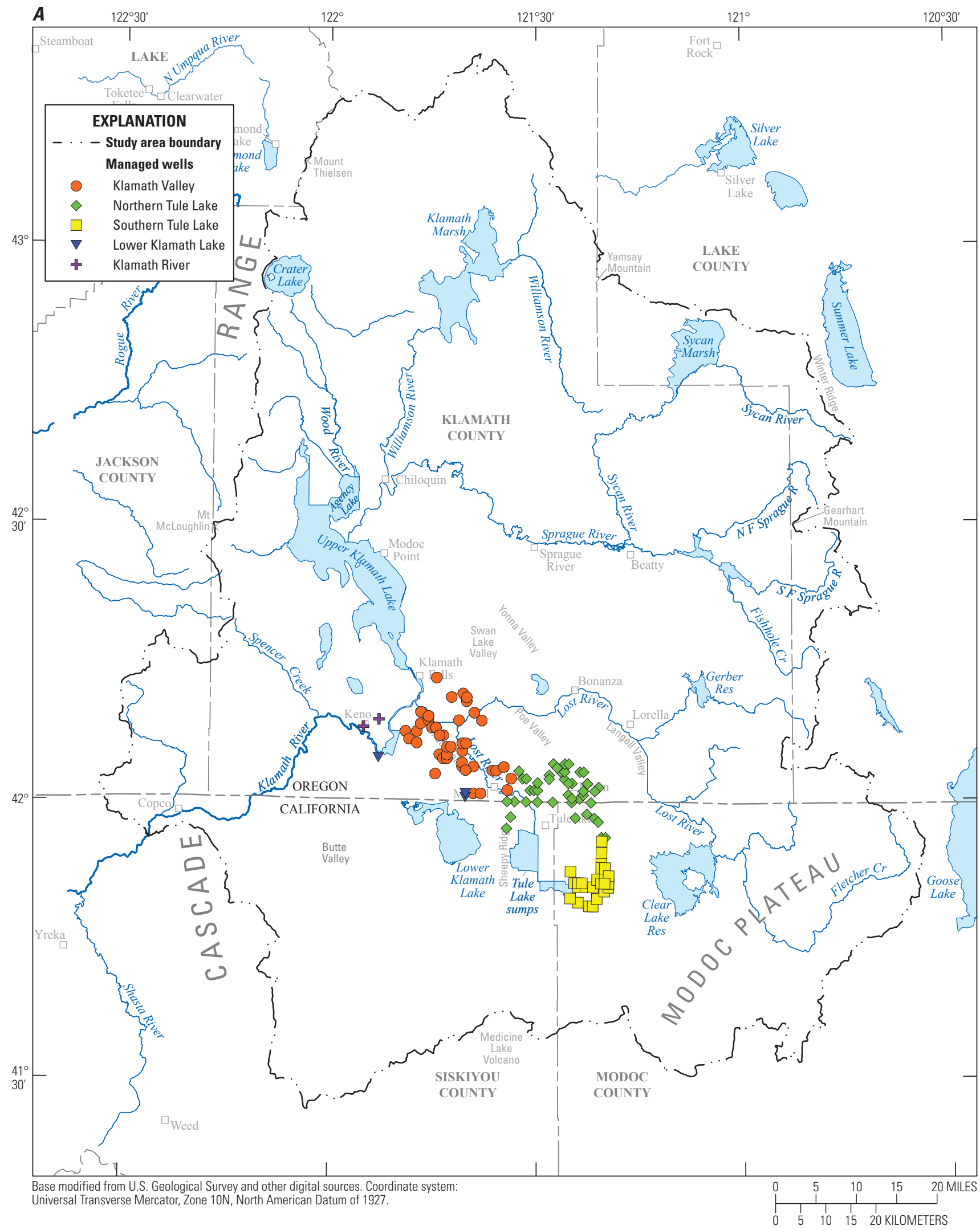

Figure 4. Locations of $(A)$ managed wells and $(B)$ drawdown and discharge constraints, upper Klamath Basin, Oregon and California. 


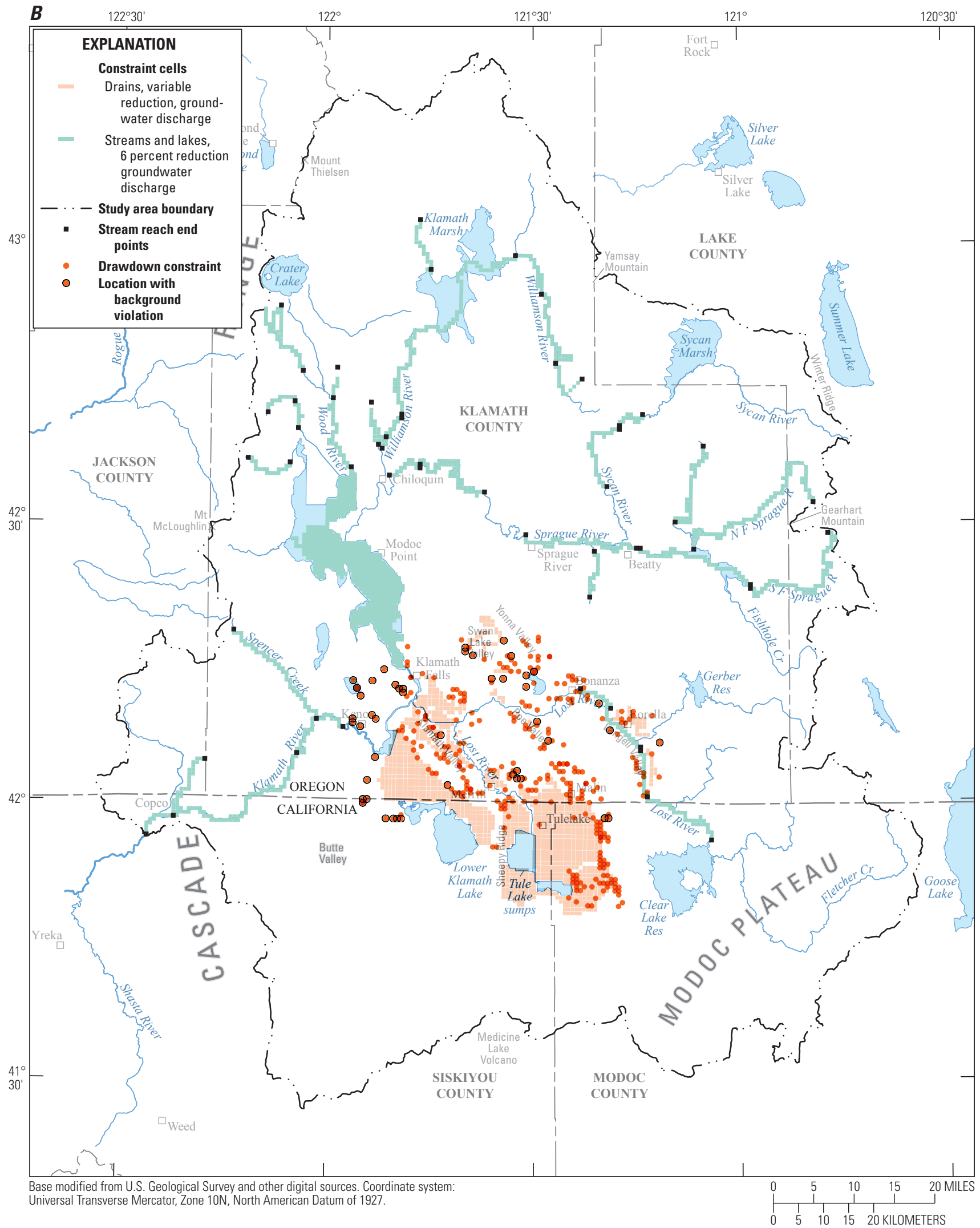

Figure 4.-Continued. 
The groundwater-management model included two seasonal drawdown constraints at each drawdown-control site in each year of the model, for a total of 23,590 seasonal drawdown constraints; 34 year-to-year drawdown constraints at each control site, for a total of 11,458 year-to-year drawdown constraints; 25 10-year drawdown constraints at each control site, for a total of 8,425 10-year drawdown constraints; and 35 minimum head constraints at each control site, for a total of 11,795 minimum head constraints. Year-toyear and 10-year drawdown constraints do not extend beyond 2004; therefore, effects of pumping that occurred after 2004 were not evaluated in the groundwater-management model.

Groundwater withdrawal is accompanied by declines in water levels that interact with surface water at various temporal and spatial scales, potentially causing reductions in groundwater discharge to streams, lakes, and drains. Constraints on the reduced groundwater discharge to streams (equation 7) required the reduction to be less than or equal to a specified maximum at the end of each of the 140 simulated water-year quarters for 34 stream reaches (fig. $4 B$ ), for a total of 4,760 groundwater discharge constraints for streams. A similar set of quarterly discharge constraints (equation 8) is defined to limit reductions in groundwater discharge to Upper Klamath Lake, for a total of 140 groundwater discharge constraints for Upper Klamath Lake. The limits to the constraints controlling groundwater discharge to streams and Upper Klamath Lake, $Q S R_{n, j, k, \max }$ and $Q L R_{j, k, \max }$, were set to 6 percent of the simulated baseline groundwater discharge, as specified in the KBRA, and were fixed in all model runs. Additional constraints were defined to limit the reduction in groundwater discharge to the Project drain system (equation 9), for a total of 140 groundwaterdischarge constraints for drains. The limit on the reduction in groundwater discharge to drains, $Q D R_{j, k, \max }$, was initially set to 20 percent of the simulated baseline groundwater discharge. The effect of the drain-discharge limit in equation 9 was tested using sensitivity analysis.

Demand constraints (equation 10) were included to limit total pumping in each year with supplemental groundwater demand, for a total of 22 groundwater-demand constraints. Constraint limits, $Q D E M_{k}$, were defined using the hypothetical groundwater demand shown in figure $3 B$. Finally, capacity constraints (equation 11) define the maximum withdrawal rate for each aggregated decision well, $Q w_{i, \max }$. Capacity limits were defined for each well included in an aggregated well group and summed to define the constraint limit for that aggregated decision variable. Pumping capacities at individual wells were determined from water-well reports obtained from the states or pump information obtained from the KWAPA. The groundwater-management model includes 1,540 capacity constraints, one for each of the decision variables.
The coupled simulation and optimization groundwatermanagement model represented by equations $1-11$ includes 1,540 decision variables and 61,870 constraints. The groundwater management model was solved using the method of sequential linear programming (Ahlfeld and Mulligan, 2000), which accounts for the nonlinearities associated with head-dependent boundaries used to model streams, lakes, drains, and evapotranspiration surfaces in the upper Klamath Basin groundwater-simulation model. Sequential linear programming solves a series of linear-programming problems, each formulated using the response matrix technique (Gorelick and others, 1993; Ahlfeld and Mulligan, 2000). The optimization model was solved in each iteration of the sequential linear programming method using the optimization software package, LINDO ${ }^{\circledR}$ (LINDO Systems Inc., 2005). The sequential solution process is continued until the optimization solution reaches convergence. The primary convergence criterion used in this study is based on the objective function value (equation 1), and requires that the change in this value from iteration $l$ to iteration $l+1$ be less than 0.1 percent. A discussion of the response-matrix approach and sequential linear programming, and their application to the upper Klamath Basin groundwater model is available in Gannett and others (2012). Detailed developments of the responsematrix technique can be found in Gorelick and others (1993) and Ahlfeld and Mulligan (2000). Example applications of the sequential linear programming approach are available in Danskin and Gorelick (1985), Danskin and Freckleton (1989), Nishikawa (1998), Reichard and others (2003), Ahlfeld and Baro-Montes (2008), and Gannett and others (2012).

\section{Variations of Groundwater Levels Under Background Conditions}

Groundwater systems are dynamic, with groundwater recharge, groundwater discharge, and groundwater levels varying in response to external stresses. The largest external stresses affecting groundwater in the upper Klamath Basin are drought cycles and groundwater pumping (Gannett and others, 2007, 2012). Drought cycles cause variations in groundwater recharge, which are manifest as fluctuations in water levels and groundwater discharge to springs and streams. Pumping also affects water levels and groundwater discharge, with the greatest effects observed near the pumping stress.

The groundwater-management model developed for this study limits short- and long-term variations in water levels through the drawdown constraints defined by equations 2-6. Unlike the groundwater-discharge constraints (equations 7-9), which limit the relative changes in groundwater discharge caused by on-Project pumping, the drawdown constraints limit 
the absolute changes in water levels and do not distinguish between changes caused by on-Project pumping and changes caused by background pumping or climate. Because of this, drawdown constraints can be violated (that is, the constraint is not met) solely in response to background pumping conditions and climate cycles. Violations under background conditions can occur in areas where (1) actual conditions are close to, or actually exceed, drawdown limits; (2) the simulated response to an external stress is larger than the true response; or (3) there are errors in the estimates of background pumping.

A pre-optimization groundwater-modeling analysis was done to identify the extent of drawdown-constraint violations caused by background pumping and climate. The simulation model was run with the on-Project pumping set to zero to identify the locations and times at which drawdown constraints are violated under background conditions. The groundwater-management model includes 337 drawdowncontrol sites with 55,268 drawdown constraints; the preoptimization groundwater-modeling analysis identified 48 locations with 1,050 background constraint violations. The locations of the drawdown constraints violated under background conditions are shown in figure $4 B$. Most drawdown constraints are located on the margins of the managed area. Twenty-five constraint locations with background violations are located along the western margin among the drawdown-control locations north of the Klamath River and in the western part of the Lower Klamath Lake region; 15 constraint locations are in the upper Lost River region. Of the remaining eight locations, two are in the Klamath Valley region and six are in the northern Tule Lake region. Five of the 48 locations with background violations are at drawdown-control sites that are co-located with managed wells. Of the 1,050 violated drawdown limits, 764 are seasonal drawdown-constraint violations, 245 are year-toyear drawdown-constraint violations, and 41 are 10-year drawdown-constraint violations. There are no violations of the minimum-head constraint (equation 6).

The groundwater-management model was modified to account for these background constraint violations and allow solution of the optimization model defined by equations $1-11$. For each of the 1,050 location and time couplets with a drawdown-constraint violation, the drawdown limit was modified. The drawdown limit $\left(D D_{\text {seas, } \max }, D D_{y 2 y, \max }\right.$, or $D D_{10 y, \text { max }}$ ) was revised to be the simulated background groundwater-elevation change plus an exceedance tolerance of $0.2 \mathrm{ft}$. The exceedance tolerance was constant across all 48 sites with background violations and all drawdownconstraint types. Alternative values of the exceedance tolerance, ranging up to $0.5 \mathrm{ft}$, also were tested, with no significant changes in the results of the groundwatermanagement model.

\section{Evaluation of Selected Alternatives}

\section{Base-Case Analysis}

The base-case optimization model uses the groundwatermanagement model described in this report. The goal of the base-case analysis is to determine the ability of the groundwater system to reduce or eliminate annual surfacewater deficits of the Project foreseen under the KBRA, and to identify the spatial and temporal pattern of pumping that best meets that goal. Subsequent analyses will explore the sensitivity to several factors - restrictiveness of drawdown constraints, drain-discharge constraint limits, additional pumping capacity, and targeted reduction of background pumping. Table 1 summarizes the alternative analyses described in this report.

The results of the base-case optimization model are summarized in figures 5-7 and table 2. The optimization model yields individual rates for each decision well shown in figure $4 \mathrm{~A}$; however, it is the spatial and temporal patterns of pumping that are useful for practical implementation of a groundwater-management strategy. The withdrawals calculated by the optimization model indicate the following:

1. The hypothetical groundwater demand is met in 14 of the 22 years that have surface-water-supply deficits (fig. 5 and table 2). The current array of on-Project wells is not able to meet the hypothetical groundwater demand in 1977, 1987, 1988, 1990-92, 1994, and 2001. Groundwater deficits - the difference between the groundwater demand and the optimized withdrawals shown in figure 5 and table 2-range from about 11,000 acre-ft in 1977 to about 45,000 acre-ft in 1991.

2. The maximum annual withdrawal calculated by the optimization model is about 60,000 acre-ft and calculated annual withdrawals for those years with unmet groundwater demand average about 54,000 acre-ft. These calculated pumping volumes are similar to the volumes of groundwater purchased as part of Reclamation's groundwater-pumping programs, which purchased a maximum of about 66,000 acre-ft and an average of about 46,000 acre-ft during 2001-07. The annual withdrawals calculated by the optimization model, however, are substantially less than the roughly 101,000 acre-ft purchased in 2010 as part of the KWAPA pumping program (fig. 2). 
Table 1. Summary of alternative groundwater-management strategies evaluated, upper Klamath Basin, Oregon and California.

[Shading used to emphasize the constraint limits that are changed from their base-case values. Constraint limits: OR, Oregon; CA, California; KRBA, Klamath Basin Restoration Agreement. DD_1 and DD_2, strategies with less restrictive drawdown limits at constraint locations in California; DD_3, strategy with more restrictive drawdown limits at all constraint locations; Drain_10 and Drain_05, strategies with more restrictive drains-constraint limits]

\begin{tabular}{|c|c|c|c|c|c|c|c|c|}
\hline \multirow{3}{*}{$\begin{array}{l}\text { Groundwater- } \\
\text { management } \\
\text { strategy }\end{array}$} & \multicolumn{8}{|c|}{ Constraint limits } \\
\hline & \multicolumn{2}{|c|}{$\begin{array}{l}\text { Seasonal drawdown } \\
\text { (feet) }\end{array}$} & \multicolumn{2}{|c|}{$\begin{array}{l}\text { Year-to-year drawdown } \\
\text { (feet) }\end{array}$} & \multicolumn{2}{|c|}{$\begin{array}{l}\text { Decadal drawdown } \\
\text { (feet) }\end{array}$} & \multicolumn{2}{|c|}{$\begin{array}{c}\text { Change in } \\
\text { groundwater discharge } \\
\text { (percent baseline) }\end{array}$} \\
\hline & OR & CA & OR & CA & OR & CA & Drains & KBRA \\
\hline Base case & 25 & 25 & 3 & 3 & 25 & 25 & 20 & 6 \\
\hline DD_1 & 25 & 37.5 & 3 & 4.5 & 25 & 25 & 20 & 6 \\
\hline DD_2 & 25 & 50 & 3 & 6 & 25 & 25 & 20 & 6 \\
\hline DD_3 & 20 & 20 & 2 & 2 & 20 & 20 & 20 & 6 \\
\hline Drain_10 & 25 & 25 & 3 & 3 & 25 & 25 & 10 & 6 \\
\hline Drain_05 & 25 & 25 & 3 & 3 & 25 & 25 & 5 & 6 \\
\hline Increase pumping capacity & 25 & 25 & 3 & 3 & 25 & 25 & 20 & 6 \\
\hline Remove background pumping & 25 & 25 & 3 & 3 & 25 & 25 & 20 & 6 \\
\hline
\end{tabular}

3. A comparison of withdrawals by region indicates the highest annual withdrawals are from the southern Tule Lake wells (table 2, fig. 4A). The highest percentage of pumping is in these wells during all years except 1973, 1986 , 1997, and 1999, and 37-53 percent $(22,000-$ 28,000 acre-ft) of the annual pumping for those years in which groundwater is unable to meet supplemental demand. Calculated annual withdrawals from the Klamath Valley region comprise 22 percent to 35 percent $(10,000$ 20,000 acre-ft) of the total annual pumping for years with unmet demand; and withdrawals from the northern Tule Lake region supply 15-24 percent (8,700-14,000 acre-ft) of the total annual pumping in years with unmet demand. Withdrawals from the Lower Klamath Lake and Klamath River regions supply a maximum of about 3,000 and 1,600 acre-ft, respectively.

4. Each of the 117 managed wells included in the groundwater-management model (fig. 4A) is active with a non-zero pumping rate at some time during the 35 -year management horizon. The frequency of well use, however, varies geographically (fig. 6). The frequently used wells - defined here as the managed wells with non-zero pumping rates in 16 or more of the 22 years with groundwater demand-are located in the southern Tule Lake, northern Tule Lake, and Klamath Valley regions where the model-calculated withdrawals are highest. The highest concentration of wells active in 16 or more years is in southern Tule Lake (ig. 6).

5. Years when groundwater demand is not met tend to have most of the calculated annual withdrawal allocated to pumping in the 3rd quarter (table 2). The only exception is 1992 , with 47 percent of the calculated pumping in the 3 rd quarter. For all other years, 3rd quarter pumping ranges from 52 to 60 percent of total withdrawals. It is likely that apportioning most withdrawal to the 3rd quarter in high-demand years allows the optimization model to increase total pumping while meeting the year-to-year drawdown limitation. Similar results were obtained in the groundwater-management analyses described in Gannet and others (2012). 
Table 2. Calculated quarterly withdrawals by pumping region and year for the base-case groundwater-management analysis, upper Klamath Basin, Oregon and California, 1970-2004.

[Shading used to emphasize years in which groundwater demand is not met. All withdrawal volumes are in acre-ft. Abbreviations: KLV, Klamath Valley wells; NTL northern Tule Lake wells; STL, southern Tule Lake wells; LKL, Lower Klamath Lake wells; KLR, Klamath River wells; Q3, third quarter; Q4, fourth quarter]

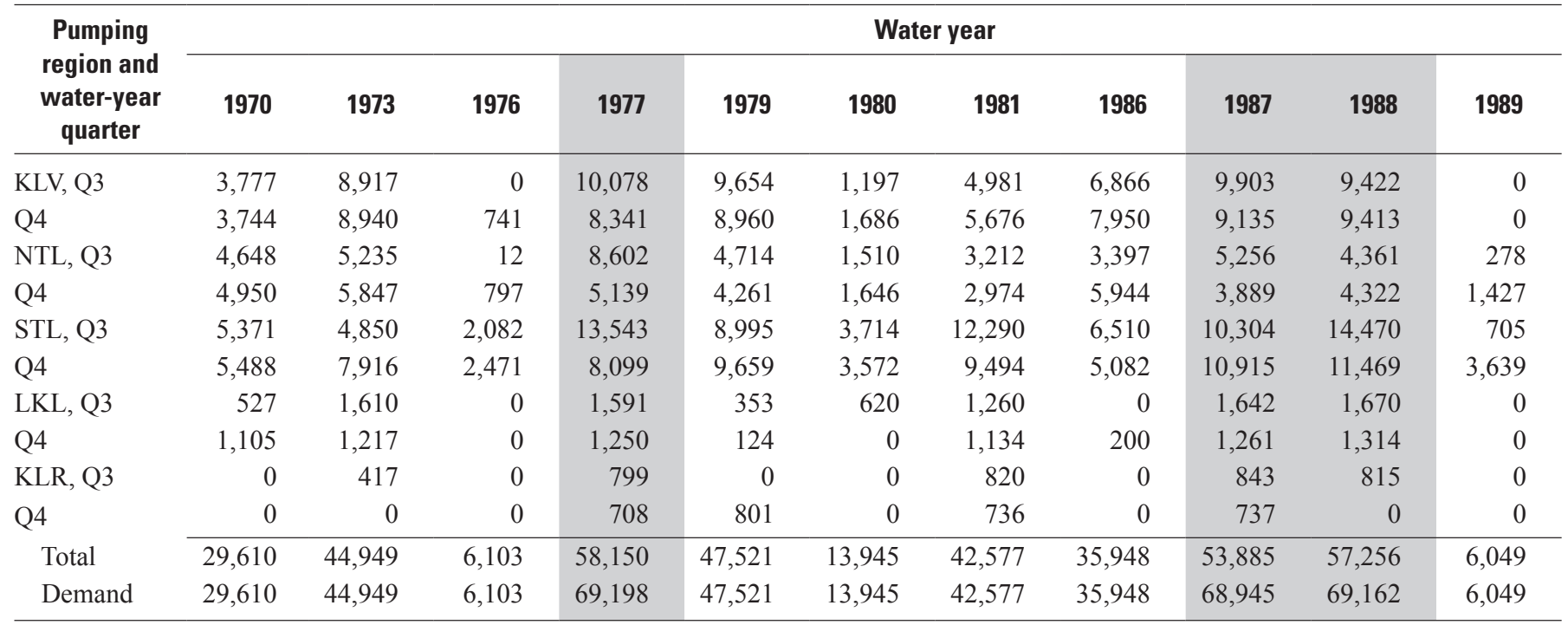

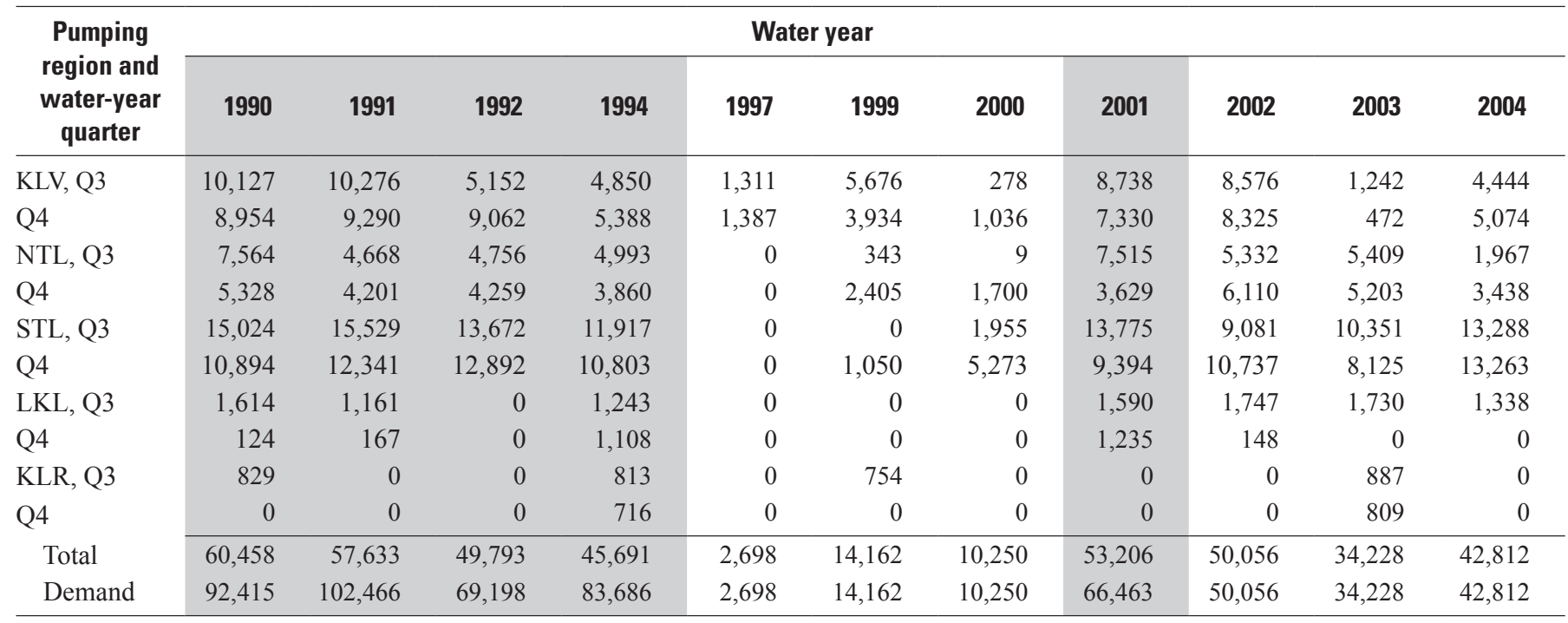




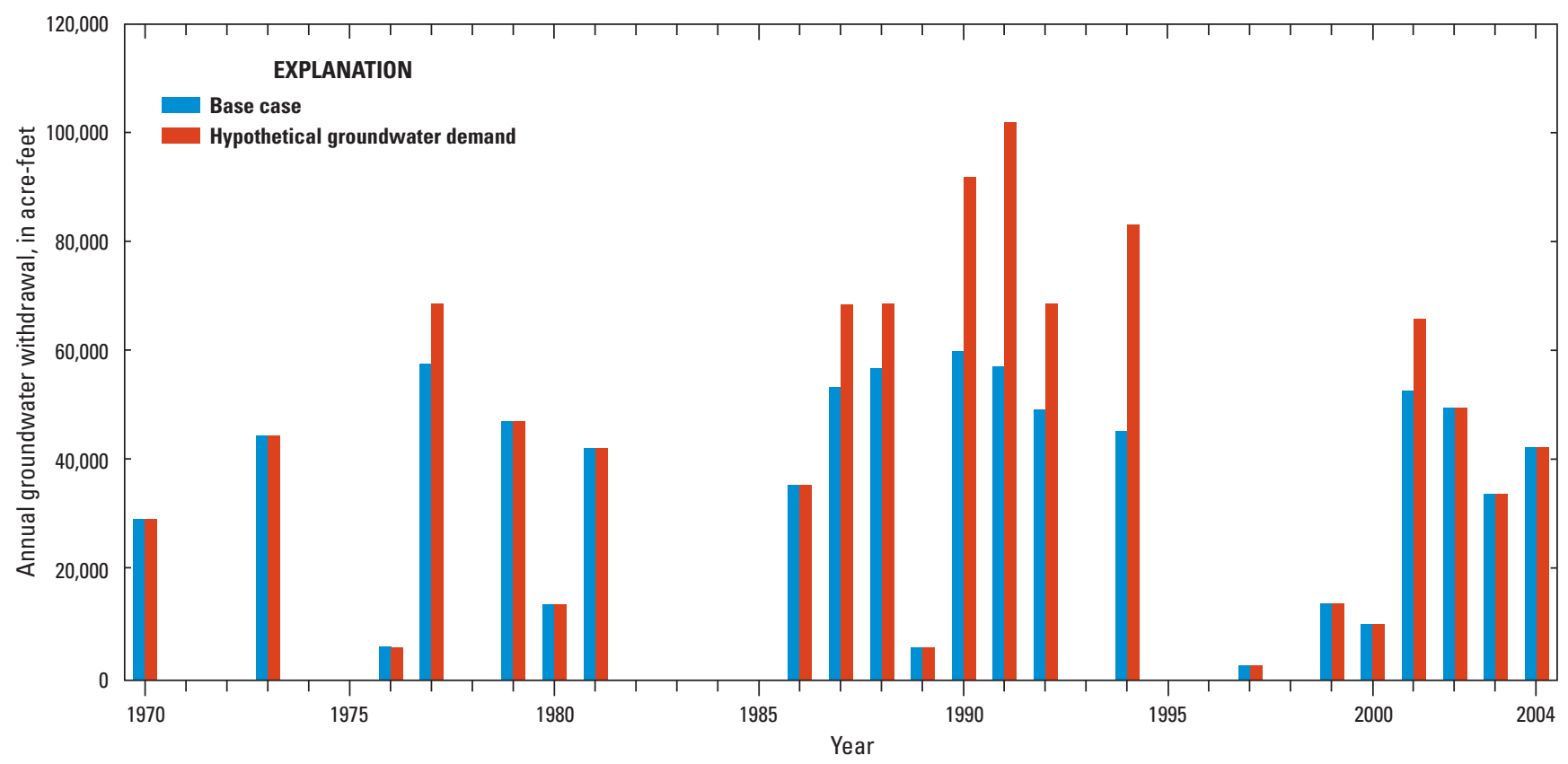

Figure 5. Results of base-case optimization model: hypothetical groundwater demand and optimized annual groundwater withdrawal, upper Klamath Basin, Oregon and California, 1970-2004. Base-case is a groundwater-management-model formulation defined in table 1.

6. Because of restrictions imposed by the groundwatermanagement-model constraints, there is considerable unused pumping capacity in the northern Tule Lake, southern Tule Lake, and Klamath Valley regions. The wells of the northern Tule Lake region contribute a maximum quarterly withdrawal of about 8,600 acre- $\mathrm{ft}$ from the 52,000 acre-ft pumping capacity (defined as the amount that could be pumped in a water-year quarter if all wells in that region were pumped at their maximum rates). Similarly, the calculated quarterly withdrawals for the wells in the southern Tule Lake region are a maximum of about 15,500 acre- $\mathrm{ft}$ from a 29,000 acre- $\mathrm{ft}$ capacity, and the calculated quarterly withdrawals for wells in the Klamath Valley region are a maximum of about 10,000 acre-ft from a 37,000 acre-ft capacity. The Lower Klamath Lake and Klamath River pumping regions have significantly smaller capacities than those of the other well groups. The calculated quarterly withdrawals for the Lower Klamath Lake region have a maximum of about 1,700 acre-ft from a 4,400 acre-ft capacity and the calculated quarterly withdrawals for wells in the Klamath River region have a maximum of about 900 acre-ft from a 1,900 acre-ft capacity. The existence of substantial amounts of unused pumping capacity in the southern Tule Lake, northern Tule Lake, and Klamath Valley regions does not mean that all wells in these regions are underutilized. A subset of wells in the Klamath Valley region has calculated pumping rates at their upper bounds.

7. The results of the base-case groundwater-management model indicate that additional pumping in the Project could be managed to avoid adverse effects to groundwater discharge that supports aquatic habitat. The groundwaterdischarge constraints related to surface-water features that support aquatic habitat (defined by equations 7 and $\underline{8}$ and shown in fig. $4 B$ ) are not limiting. These constraints are defined according to the rules given in the KBRA and the reduction in groundwater discharge is limited to be no greater than 6 percent of the baseline discharge. The simulated base-case pumping strategy calculated reductions of groundwater discharge at the constraint sites in figure $4 B$ to be less than 0.5 percent of baseline groundwater discharge. A comparison of massbalance components of the baseline and optimized groundwater-simulation models indicates that most on-Project pumping is derived from storage and reduced groundwater discharge to drains. Results obtained for all the groundwater-management scenarios evaluated for this report were similar and consistent with the results reported in Gannett and others (2012). 


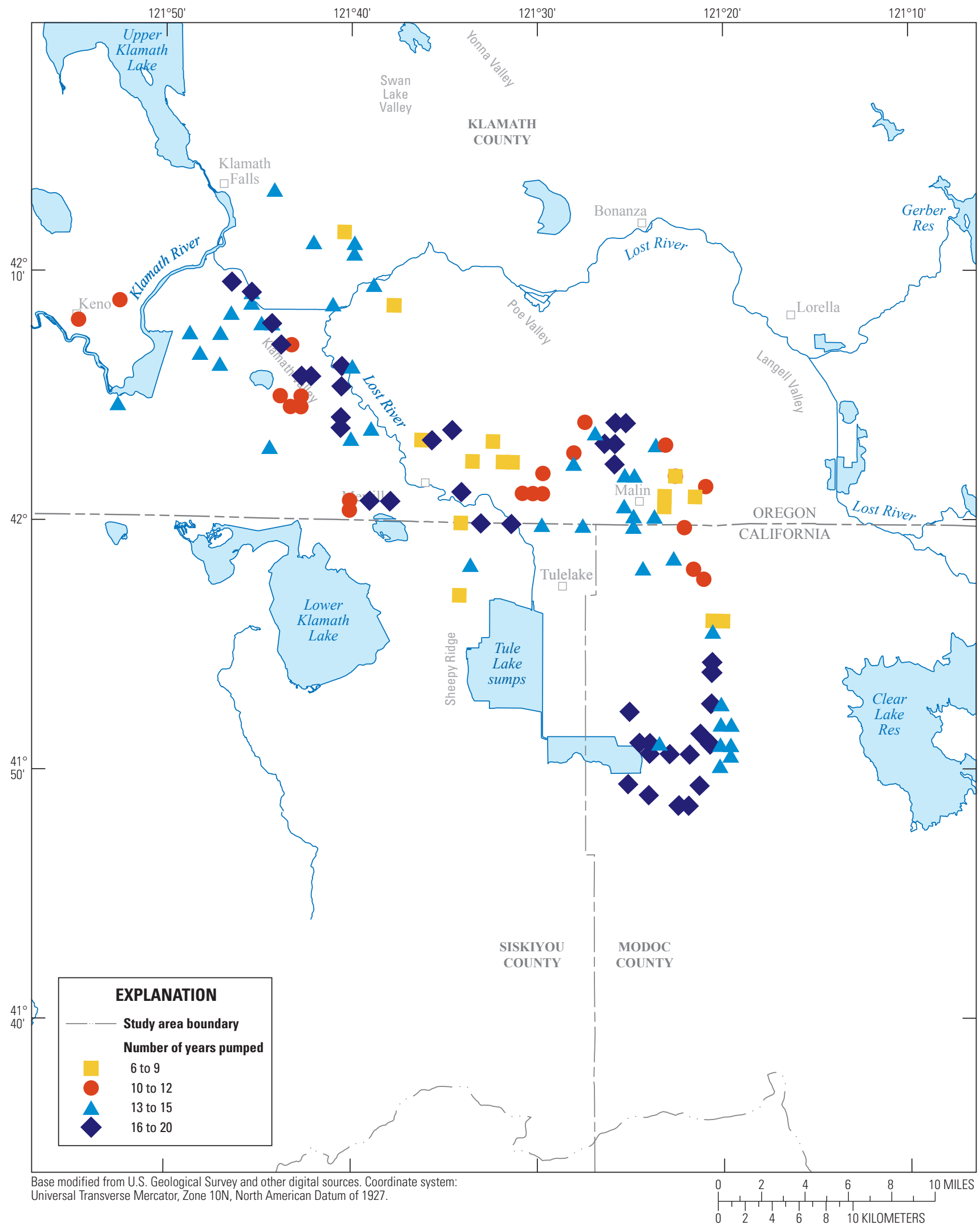

Figure 6. Frequency of optimized-well usage in base-case groundwater-management analysis, upper Klamath Basin, Oregon and California. 


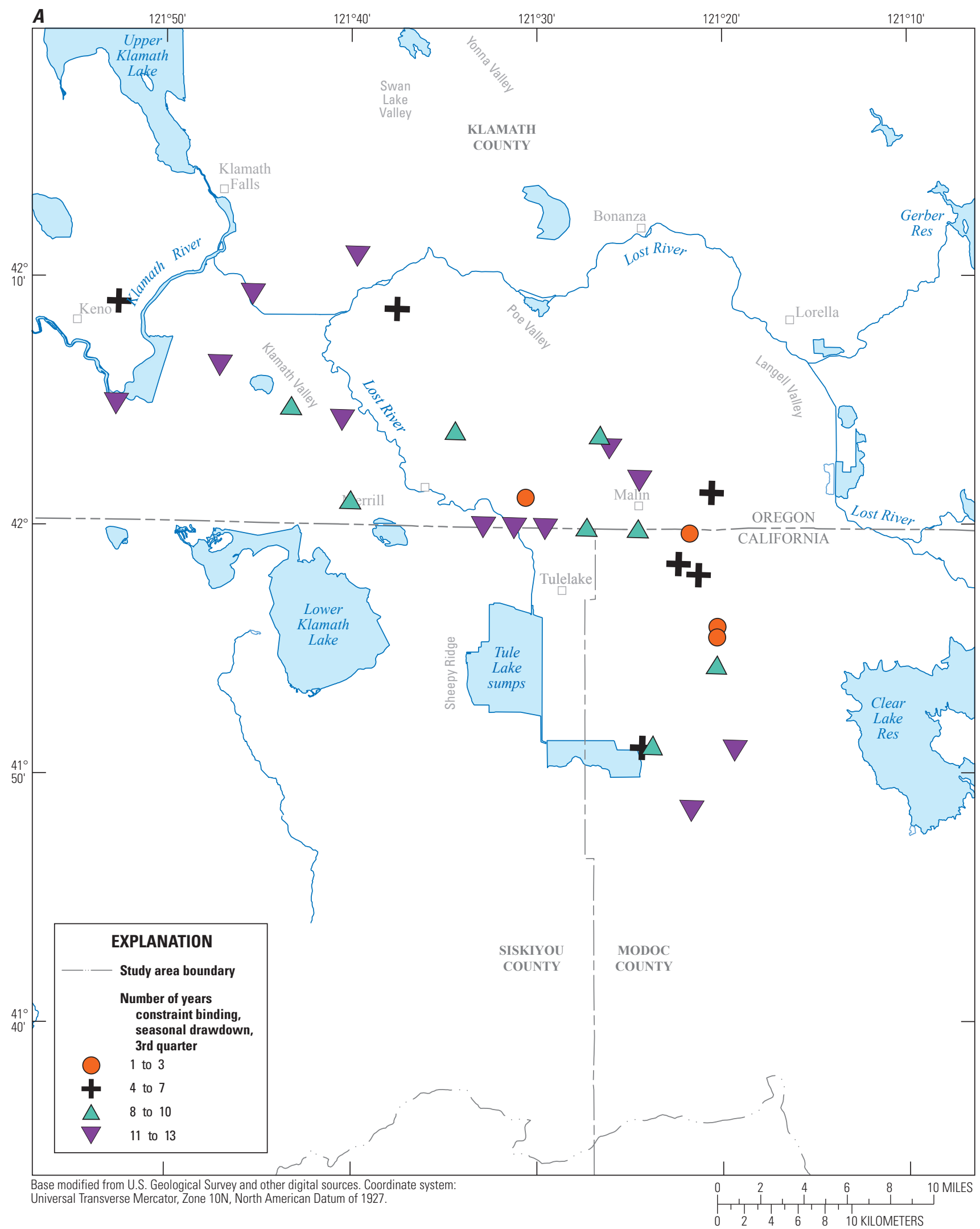

Figure 7. Frequency of binding drawdown constraints in the base-case groundwater-management analysis for $(A)$ 3rd quarter seasonal-drawdown constraints; $(B)$ 4th quarter seasonal-drawdown constraints; and $(C)$ year-to-year drawdown constraints, upper Klamath Basin, Oregon and California. 


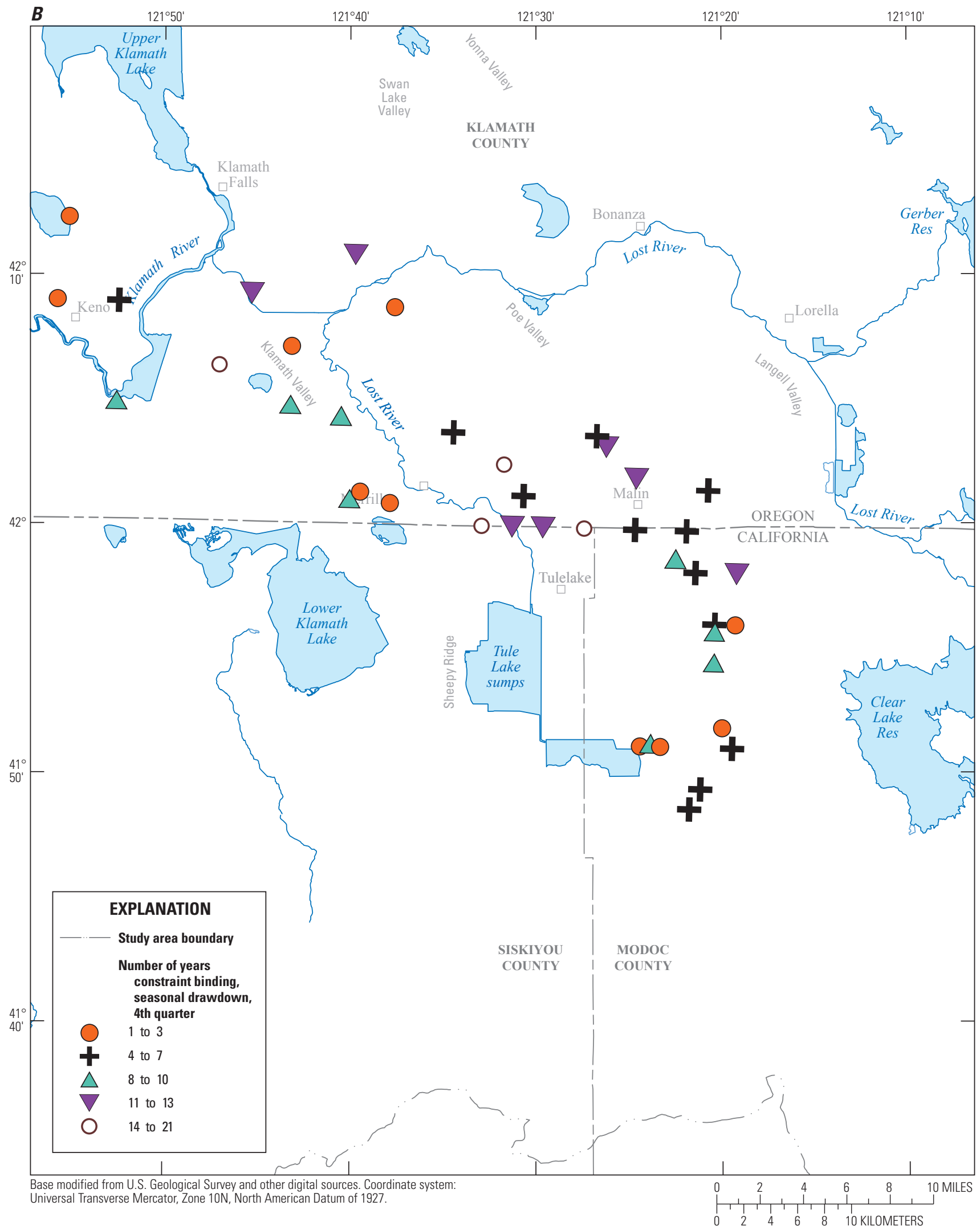

Figure 7.-Continued. 


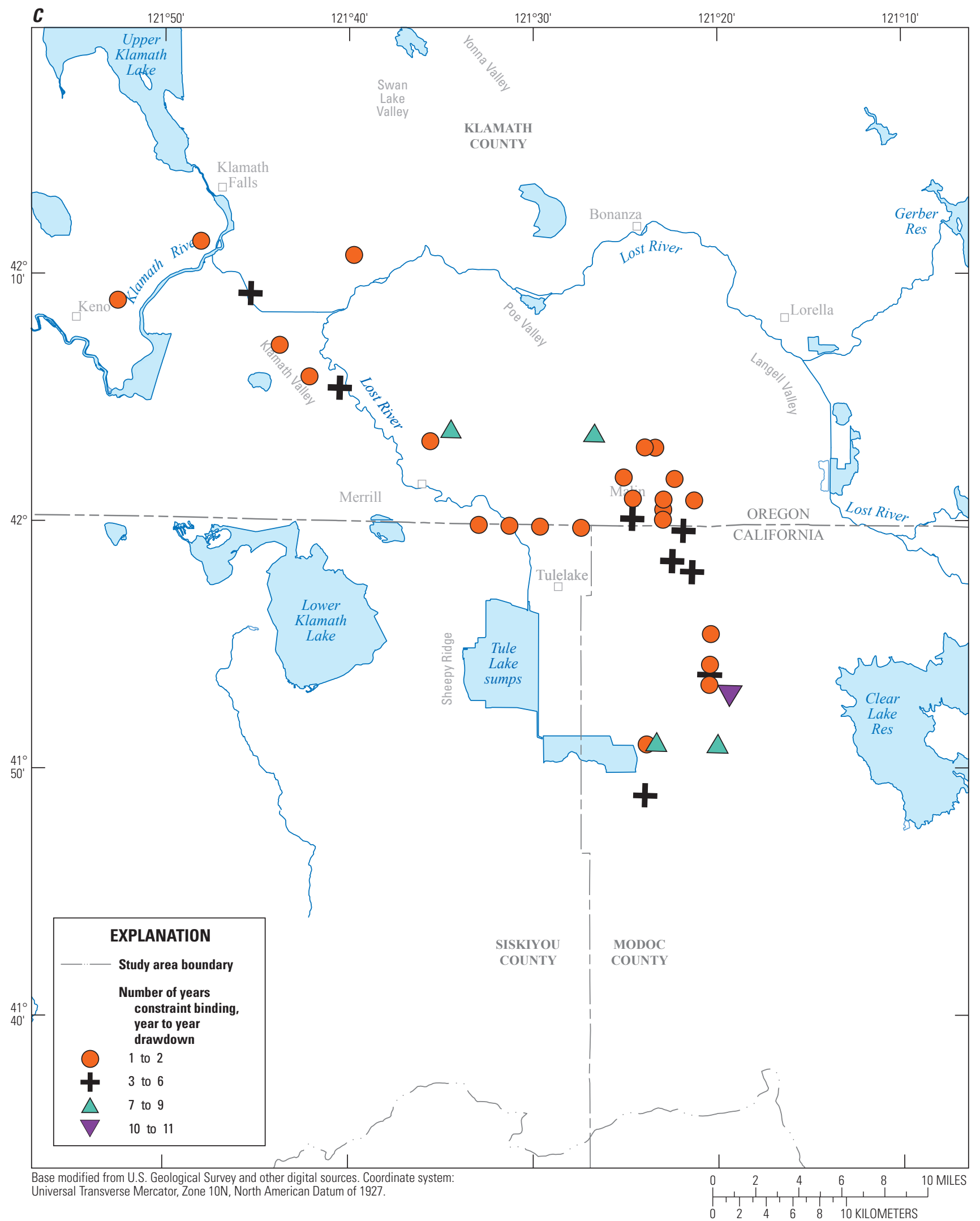

Figure 7.-Continued. 
The groundwater-management model includes constraints to control the effects to groundwater and surface-water resources within and outside the Project. With the spatial and temporal patterns of withdrawal summarized in table 2 and figure 5 , the binding constraints (those constraints calculated to be at their limits) were associated with seasonal, year-to-year, and 10-year drawdowns (equations 2-5). Of the 677 binding constraints that occurred during the entire 35-year management period, 576 are associated with seasonal drawdowns (264 are binding in the 3rd quarter and 312 are binding in the 4th quarter), 98 are associated with year-to-year drawdowns, and 3 are associated with 10-year drawdowns. The locations and the frequency of occurrence of the binding drawdown constraints are summarized in figure 7. Binding seasonal drawdown constraints that occur in the 3rd quarter are at 30 locations shown in figure $7 \mathrm{~A}$, with all 30 binding constraint sites co-located with managed wells. The wells with frequently binding constraints occur primarily in the southern Tule Lake, northern Tule Lake, and Klamath Valley regions where the highest pumping volumes occur. Similarly, for the 4th quarter seasonal drawdown constraints, 36 of the 41 binding drawdown sites are in model cells with managed wells; the locations with the highest frequency of binding constraints occurred in the Klamath Valley and northern Tule Lake regions (fig. 7B). For the year-to-year drawdown constraints, binding constraints occurred at 36 locations, with 30 co-located with managed wells; the locations of the frequently binding constraints are in the Klamath Valley, northern Tule Lake, and southern Tule Lake regions (fig. 7C). The binding 10-year drawdown constraints (not shown in figure 7) are north of the Klamath River at two background (non-managed) well sites.

The binding drawdown constraints summarized in figure 7 include constraints that are violated in response to background pumping and climate cycles. The groundwatermanagement model includes 1,050 drawdown constraints that were modified to account for violations under background conditions (fig. $4 B$ ). Of the 677 binding drawdown constraints in the base-case analysis, 33 occurred in the set of modified constraints associated with violations under background conditions. The subset of 33 constraints ( 29 seasonal, 1 yearto-year, and three 10-year drawdown constraints) is located at 7 drawdown locations, of which 3 are co-located with managed wells. The spatial and temporal distribution of these 33 constraints indicates they have varying effects on the results of the groundwater-management model. Eighteen of the 33 binding constraints occur in years when the groundwatermanagement model calculation meets supplemental irrigation demand. The remaining 15 binding constraints occur in years with unmet groundwater demand and are co-located with 3 decision wells. Thirteen constraints are co-located with a decision well in the northern Tule Lake region that has an aggregated pumping capacity of approximately 4,100 acre-ft; pumping volumes calculated by the groundwater-management model for this decision well are less than 400 acre-ft. One constraint is co-located with a decision well in the Klamath Valley region that has an aggregated pumping capacity of approximately 6,800 acre-ft; pumping volumes calculated by the groundwater-management model for this decision well have a maximum of approximately 1,100 acre-ft. The final constraint is co-located with a decision well in the Klamath River well group that has an aggregated pumping capacity of approximately 1,900 acre-ft; pumping volumes calculated by the groundwater-management model for this decision well have a maximum of approximately 900 acre-ft. The belowcapacity pumping volumes calculated for these three decision wells occur throughout the management period, including years when the drawdown constraints are not binding under background conditions.

Fluctuations in groundwater levels due to background pumping and climate were observed to varying degrees at all drawdown-control sites, and constraint violations due to background conditions were expected. In the base-case groundwater-management analysis, the constraint violations under background conditions potentially affect maximum rates at a small number of individual wells. Because the groundwater-management model includes 117 wells distributed over a large geographic region, the effect of these violations on the overall management-model results is small. Future analyses of groundwater management in the upper Klamath Basin should consider regulatory controls that might affect groundwater development in areas where drawdown constraints are violated under background conditions.

\section{Evaluation of Sensitivity to Less Restrictive Drawdown Constraints in California}

The State of California provides three basic methods for managing groundwater resources: (1) court adjudication, (2) local government ordinances, and (3) management by local agencies under authority granted by State statutes (California Department of Water Resources, 2003). Presently (2013) these controls are not applied to groundwater development in the California part of the upper Klamath Basin. As a result, alternative values for drawdown limits in the California part of the Project may be considered in future groundwater planning.

The first sensitivity analysis tests the effect of less restrictive seasonal and year-to-year drawdown constraints in the California part of the Project, as summarized in table 1. The base-case optimization model constrains seasonal drawdown (25 ft), year-to-year drawdown ( $3 \mathrm{ft}$ ), and decadal drawdown (25 ft) according to limits assigned by the OWRD. In this two-part sensitivity analysis, the drawdown limits for seasonal-drawdown constraints (equations 2 and 3 ) and yearto-year drawdown constraints (equation 4) are first changed to 37.5 and $4.5 \mathrm{ft}$, respectively, at all drawdown-control locations in the California part of the model (scenario DD_1 in table 1). 
A second formulation of the groundwater-management model changes the constraints to $50 \mathrm{ft}$ for seasonal drawdown and $6 \mathrm{ft}$ for year-to-year drawdown (scenario DD_2 in table 1). For both analyses, the decadal drawdown limit remains at the base-case value of $25 \mathrm{ft}$; all other aspects of the groundwatermanagement model also remain the same as in the base-case analysis. Applying less restrictive seasonal and year-to-year drawdown limits while maintaining the long-term drawdown limit at the base-case value of $25 \mathrm{ft}$ will allow for concentrated pumping in years with greater groundwater demand while limiting the long-term effects of sustained groundwater withdrawal. The drawdown limits used in these analyses were selected for illustration purposes.

Relaxing the drawdown limits allows for substantially increased pumping in years when groundwater demand was not met in the base-case analysis. Quarterly groundwater withdrawals by pumping region are given in tables 3 and $\underline{4}$, and the trade-off between total annual groundwater withdrawal and drawdown limits is shown in figure 8. For both scenarios with less restrictive drawdown constraints, groundwater withdrawals met demand in 1977, 1987, and 1988, which had deficits of roughly 11,000, 15,000, and 12,000 acre-ft, respectively, in the base-case analysis. For drawdown scenario DD_2, demand also was met in 2001, which has a deficit of roughly 13,000 acre-ft in the base-case analysis. The annual withdrawals calculated by the model increased by as much as about 22,000 acre-ft when the seasonal and year-to-year drawdown limits were 37.5 and $4.5 \mathrm{ft}$, respectively, and increased by as much as about 31,000 acre-ft when the limits were increased to 50 and $6 \mathrm{ft}$. The average groundwater withdrawal in years with unmet groundwater demand was about 70,000 acre-ft in drawdown scenario DD_1 and 76,000 acre-ft in drawdown scenario DD_2 (compared to an average withdrawal of about 54,000 acre-ft in the base-case analysis). In drawdown scenario DD_1, annual groundwater withdrawals calculated by the optimization model meet groundwater demand in 17 of 22 years; in scenario DD_2, calculated withdrawals meet demand in 18 of 22 years.

The effects of varying the drawdown-constraint limits occur primarily in the pumping amounts calculated for the southern Tule Lake, northern Tule Lake, and Klamath Valley well groups, which have the highest annual withdrawals in the base-case analysis. The pumping amounts calculated for these well groups display the highest sensitivity to changes in the formulation of the groundwater-management model for all scenarios tested in this study; therefore, the discussion in the remainder of the report will emphasize the changes to calculated withdrawals for these three regions that result from changes in the formulation of the groundwater-management model.

The annual groundwater withdrawals for southern Tule Lake, northern Tule Lake, and Klamath Valley well groups for the base-case and less restrictive drawdown analyses are shown in figure 9 . The pumping volumes shown in figure 9 are for the years with unmet groundwater demand in the base-case optimization model (fig. 5 and table 2). The largest changes in

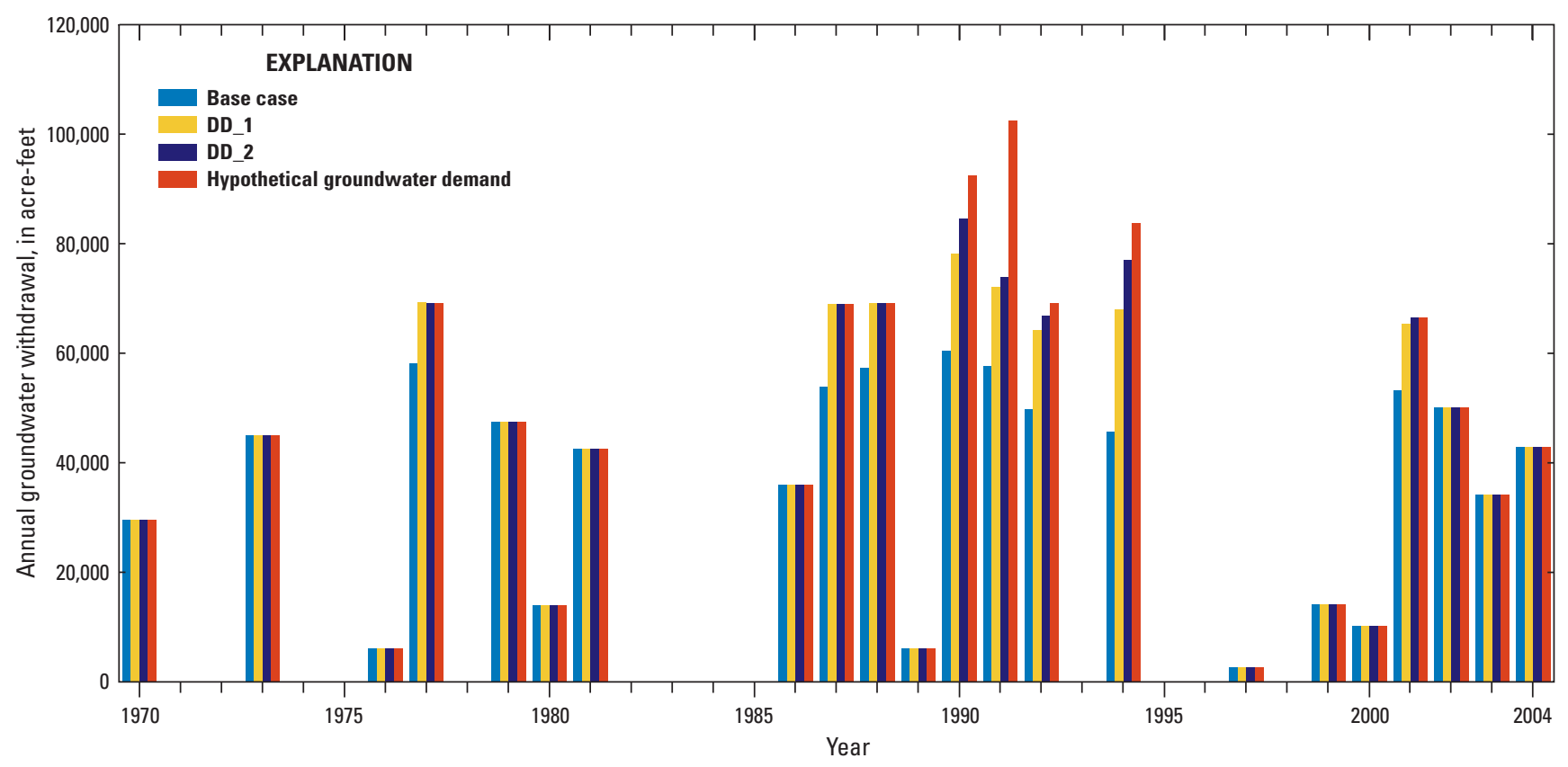

Figure 8. Sensitivity of optimization results to less restrictive drawdown-constraint limits in the California part of the model, upper Klamath Basin, Oregon and California, 1970-2004. Base-case, DD_1, and DD_2 are groundwatermanagement-model formulations defined in table 1. 
Table 3. Calculated quarterly withdrawals by pumping region and year based on analysis of less restrictive drawdown-constraint limits in the California part of the groundwater-management model for scenario DD_1, upper Klamath Basin, Oregon and California, 1970-2004.

[Scenario DD_1. Seasonal drawdown limit is 37.5 feet and year-to-year drawdown limit is 4.5 feet at constraint locations in California. Shading used to emphasize years in which groundwater demand is not met. All withdrawal volumes are in acre-ft. Abbreviations: KLV, Klamath Valley wells; NTL northern Tule Lake wells; STL, southern Tule Lake wells; LKL, Lower Klamath Lake wells; KLR, Klamath River wells; Q3, third quarter; Q4, fourth quarter]

\begin{tabular}{|c|c|c|c|c|c|c|c|c|c|c|c|}
\hline \multirow{2}{*}{$\begin{array}{l}\text { Pumping } \\
\text { region and } \\
\text { water-year } \\
\text { quarter }\end{array}$} & \multicolumn{11}{|c|}{ Water year } \\
\hline & 1970 & 1973 & 1976 & 1977 & 1979 & 1980 & 1981 & 1986 & 1987 & 1988 & 1989 \\
\hline KLV, Q3 & 6,340 & 6,166 & 0 & 9,950 & 3,598 & 1,311 & 5,265 & 8,828 & 9,873 & 9,508 & 0 \\
\hline Q4 & 2,604 & 6,950 & 753 & 8,340 & 7,654 & 3,283 & 7,032 & 6,992 & 9,166 & 8,822 & 71 \\
\hline NTL, Q3 & 4,115 & 7,383 & 14 & 9,402 & 4,374 & 804 & 2,563 & 1,256 & 5,493 & 3,064 & 5 \\
\hline STL, Q3 & 8,146 & 8,617 & 996 & 20,336 & 13,984 & 0 & 14,823 & 12,863 & 21,955 & 23,322 & 0 \\
\hline Q4 & 5,241 & 8,769 & 2,887 & 10,521 & 13,815 & 4,838 & 6,703 & 3,847 & 11,055 & 16,407 & 4,174 \\
\hline LKL, Q3 & 387 & 735 & 0 & 1,591 & 357 & 1,729 & 1,263 & 0 & 1,636 & 1,666 & 0 \\
\hline Q4 & 1,114 & 1,127 & 0 & 1,250 & 125 & 327 & 1,140 & 0 & 1,254 & 1,311 & 0 \\
\hline KLR, Q3 & 0 & 0 & 0 & 799 & 877 & 0 & 819 & 0 & 842 & 808 & 0 \\
\hline
\end{tabular}

\begin{tabular}{|c|c|c|c|c|c|c|c|c|c|c|c|}
\hline \multirow{2}{*}{$\begin{array}{c}\text { Pumping } \\
\text { region and } \\
\text { water-year } \\
\text { quarter }\end{array}$} & \multicolumn{11}{|c|}{ Water year } \\
\hline & 1990 & 1991 & 1992 & 1994 & 1997 & 1999 & 2000 & 2001 & 2002 & 2003 & 2004 \\
\hline KLV, Q3 & 10,130 & 9,263 & 4,391 & 4,848 & 0 & 703 & 728 & 9,011 & 3,060 & 0 & 7,809 \\
\hline Q4 & 9,047 & 4,187 & 4,166 & 5,027 & 1,724 & 1,747 & 2,020 & 7,959 & 2,107 & 1,050 & 3,470 \\
\hline NTL, Q3 & 10,521 & 9,369 & 10,960 & 11,122 & 242 & 1,711 & 25 & 8,710 & 5,683 & 5,892 & 1,425 \\
\hline STL, Q3 & 22,904 & 23,455 & 23,617 & 22,002 & 0 & 1,123 & 1,460 & 20,305 & 17,471 & 7,159 & 12,938 \\
\hline Q4 & 14,438 & 15,890 & 10,370 & 13,913 & 0 & 2,547 & 4,656 & 11,768 & 14,404 & 16,171 & 11,301 \\
\hline LKL, Q3 & 1,614 & 1,360 & 1,297 & 1,245 & 0 & 1,391 & 0 & 1,590 & 0 & 392 & 377 \\
\hline Q4 & 1,261 & 1,415 & 0 & 1111 & 0 & 0 & 0 & 1,233 & 216 & 198 & 0 \\
\hline KLR, Q3 & 832 & 370 & 0 & 813 & 271 & 189 & 0 & 0 & 0 & 0 & 0 \\
\hline
\end{tabular}

groundwater withdrawals occur in the southern Tule Lake well group (fig. 9A), which is entirely in the California part of the basin. In drawdown scenario DD_1, the calculated withdrawals from the southern Tule Lake wells reach a maximum of about 40,000 acre-ft (compare to the base-case analysis, which had a maximum withdrawal at southern Tule Lake wells of 28,000 acre-ft). In scenario DD_2, the calculated withdrawals at the southern Tule Lake wells reach a maximum of about 52,000 acre-ft. There also is an increase in the maximum annual withdrawals from the northern Tule Lake wells (fig. 9B), which provide a maximum of about 20,000 acre-feet in drawdown scenario DD_1 and 19,000 acre-ft in scenario DD_2, as compared to a maximum of 14,000 acre- $\mathrm{ft}$ in the base-case analysis. However, during the entire management period, the volumes pumped from the northern Tule Lake wells are reduced in some years when compared to the base-case optimization results. For example, in scenario DD_2, there are substantial reductions in groundwater withdrawals from the northern Tule 
Table 4. Calculated quarterly withdrawals by pumping region and year based on analysis of less restrictive drawdown-constraint limits in the California part of the groundwater-management model for scenario DD_2, upper Klamath Basin, Oregon and California, 1970-2004.

[Scenario DD_2. Seasonal drawdown limit is 50 feet and year-to-year drawdown limit is 6 feet at constraint locations in California. Shading used to emphasize years in which groundwater demand is not met. All withdrawal volumes are in acre-ft. Abbreviations: KLV, Klamath Valley wells; NTL northern Tule Lake wells; STL, southern Tule Lake wells; LKL, Lower Klamath Lake wells; KLR, Klamath River wells; Q3, third quarter; Q4, fourth quarter]

\begin{tabular}{|c|c|c|c|c|c|c|c|c|c|c|c|}
\hline \multirow{2}{*}{$\begin{array}{l}\text { Pumping } \\
\text { region and } \\
\text { water-year } \\
\text { quarter }\end{array}$} & \multicolumn{11}{|c|}{ Water year } \\
\hline & 1970 & 1973 & 1976 & 1977 & 1979 & 1980 & 1981 & 1986 & 1987 & 1988 & 1989 \\
\hline KLV, Q3 & 8,160 & 8,133 & 0 & 9,203 & 9,326 & 3,951 & 5,160 & 8,292 & 9,879 & 9,671 & 0 \\
\hline Q4 & 8,305 & 8,390 & 210 & 8,711 & 7,690 & 3,884 & 6,076 & 3,369 & 8,963 & 8,802 & 159 \\
\hline NTL, Q3 & 1,644 & 2,057 & 1,221 & 5,507 & 1,825 & 1,276 & 3,067 & 444 & 3,379 & 316 & 6 \\
\hline STL, Q3 & 5,407 & 14,975 & 3,454 & 26,318 & 12,210 & 2,923 & 16,924 & 15,352 & 26,390 & 28,187 & 0 \\
\hline Q4 & 3,038 & 6,373 & 976 & 12,110 & 15,546 & 0 & 5,407 & 8,249 & 14,286 & 18,807 & 4,869 \\
\hline LKL, Q3 & 500 & 1,611 & 0 & 1,597 & 0 & 1,345 & 1,264 & 0 & 1,635 & 1,666 & 0 \\
\hline Q4 & 1,107 & 1,218 & 0 & 1,253 & 0 & 22 & 1,141 & 0 & 1,254 & 128 & 0 \\
\hline KLR, Q3 & 0 & 421 & 0 & 800 & 0 & 0 & 819 & 0 & 843 & 826 & 0 \\
\hline
\end{tabular}

\begin{tabular}{|c|c|c|c|c|c|c|c|c|c|c|c|}
\hline \multirow{2}{*}{$\begin{array}{l}\text { Pumping } \\
\text { region and } \\
\text { water-year } \\
\text { quarter }\end{array}$} & \multicolumn{11}{|c|}{ Water year } \\
\hline & 1990 & 1991 & 1992 & 1994 & 1997 & 1999 & 2000 & 2001 & 2002 & 2003 & 2004 \\
\hline KLV, Q3 & 10,133 & 7,332 & 3,696 & 5,622 & 507 & 0 & 3,438 & 6,777 & 3,259 & 4,643 & 565 \\
\hline Q4 & 8,940 & 3,601 & 3,871 & 5,007 & 0 & 1,626 & 1,526 & 8,006 & 2,387 & 3,244 & 530 \\
\hline NTL, Q3 & 10,445 & 6,779 & 7,564 & 10,993 & 1,263 & 1,975 & 133 & 6,228 & 3,988 & 4,182 & 1,710 \\
\hline STL, Q3 & 27,876 & 28,182 & 28,317 & 27,750 & 407 & 3,456 & 305 & 17,513 & 21,471 & 5,580 & 20,146 \\
\hline Q4 & 18,308 & 23,516 & 13,501 & 16,046 & 0 & 3,012 & 2,635 & 18,250 & 8,826 & 11,029 & 14,581 \\
\hline LKL, Q3 & 1,613 & 1,360 & 1,282 & 1,245 & 0 & 1,157 & 0 & 1,598 & 370 & 0 & 0 \\
\hline Q4 & 1,260 & 166 & 0 & 1,110 & 0 & 0 & 0 & 1,239 & 1,491 & 0 & 0 \\
\hline KLR, Q3 & 829 & 891 & 0 & 812 & 277 & 0 & 836 & 0 & 859 & 0 & 862 \\
\hline
\end{tabular}

Lake wells in 1977, 1987, and 1988, when compared to the basecase analysis. This occurs because the less restrictive drawdown constraints allow groundwater demand for these years to be satisfied through increased withdrawals at the southern Tule Lake wells. As a result, groundwater withdrawal at the northern Tule Lake wells can be reduced.

In contrast to the base-case analysis, the drain-discharge constraint (equation 9) is binding in the scenarios DD_1 and DD_2. As a result, the increased withdrawals are accompanied in some years by reduced withdrawals from the Klamath Valley region of the model, as shown in figure $9 C$. This trade-off is required to balance the increased pumping from the California part of the model and the associated effects on groundwater discharge to the Project drain system. In scenario DD_1, the drain-discharge constraint becomes binding at the end of 1991 and again at the end of 1992; and in scenario DD_2, the constraint is binding in 1990, 1991, 1992, and 1994. The effects of the binding drain-discharge constraints are apparent in the annual pumping amounts for 1991 and 1992. To maintain a feasible solution while maximizing total pumping amounts 

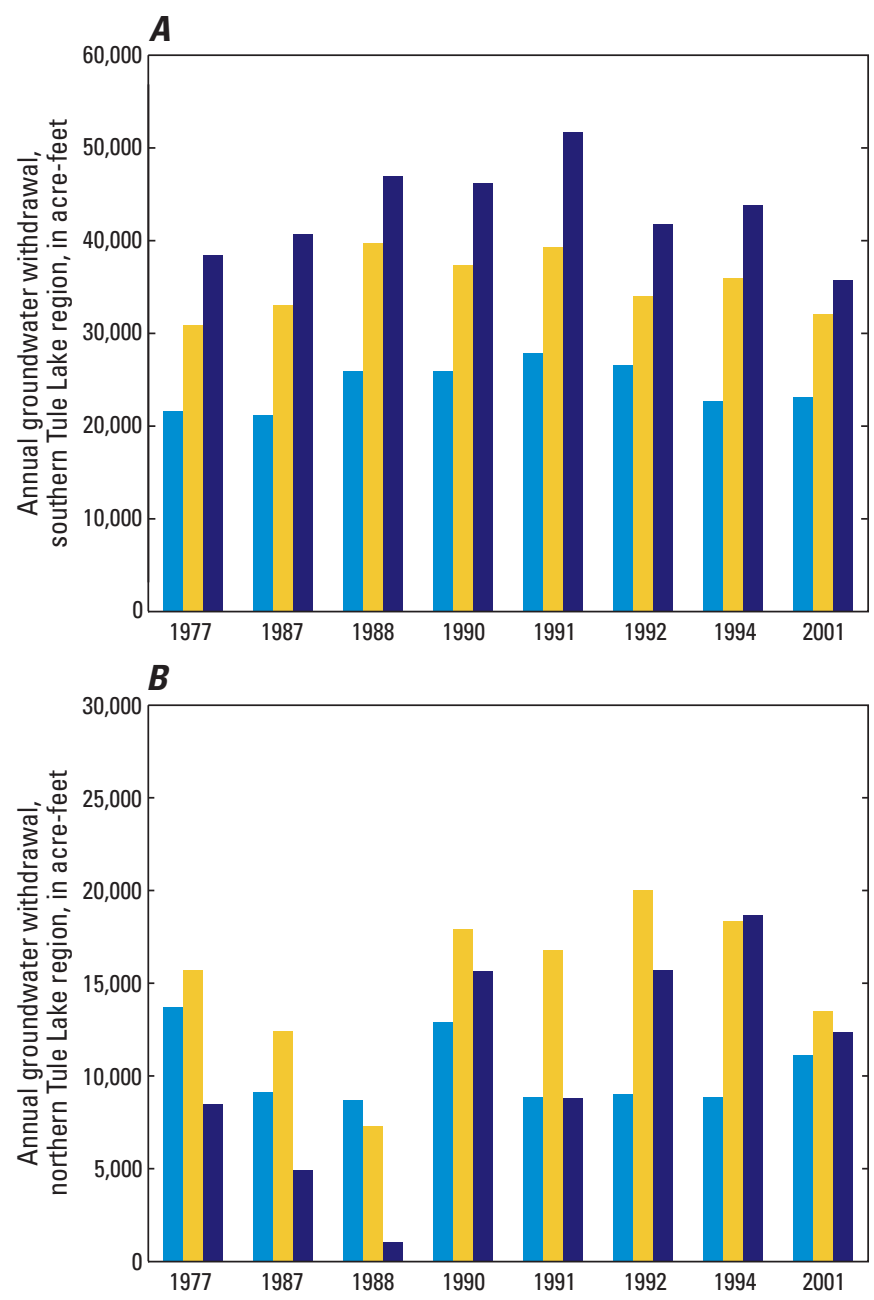

across all managed wells, withdrawals from the Klamath Valley well group are reduced by as much as about 6,000 acre-ft (scenario DD 1) and 9,000 acre-ft (scenario DD 2), when compared to the base-case results. The binding drain-discharge constraints likely also affect the amounts pumped in the northern Tule Lake region; the optimized annual withdrawals for these wells are reduced in 1990, 1991, and 1992 when the drawdown constraints are changed from scenario DD_1 to scenario DD_2 (fig. $9 B$ ).

The introduction of binding drain-discharge constraints is accompanied by a reduction in the number of binding drawdown constraints. In the base-case analysis, there are 677 binding drawdown constraints across the entire management period. In scenario DD_1, there are 648 binding drawdown constraints (533 seasonal, 111 year-to-year, and four 10-year) and in scenario DD_2, there are 477 binding drawdown constraints (398 seasonal, 77 year-to-year, and two 10-year). The reduction in the number of binding drawdown constraints occurs because of the reduced pumping in the northern Tule Lake and Klamath

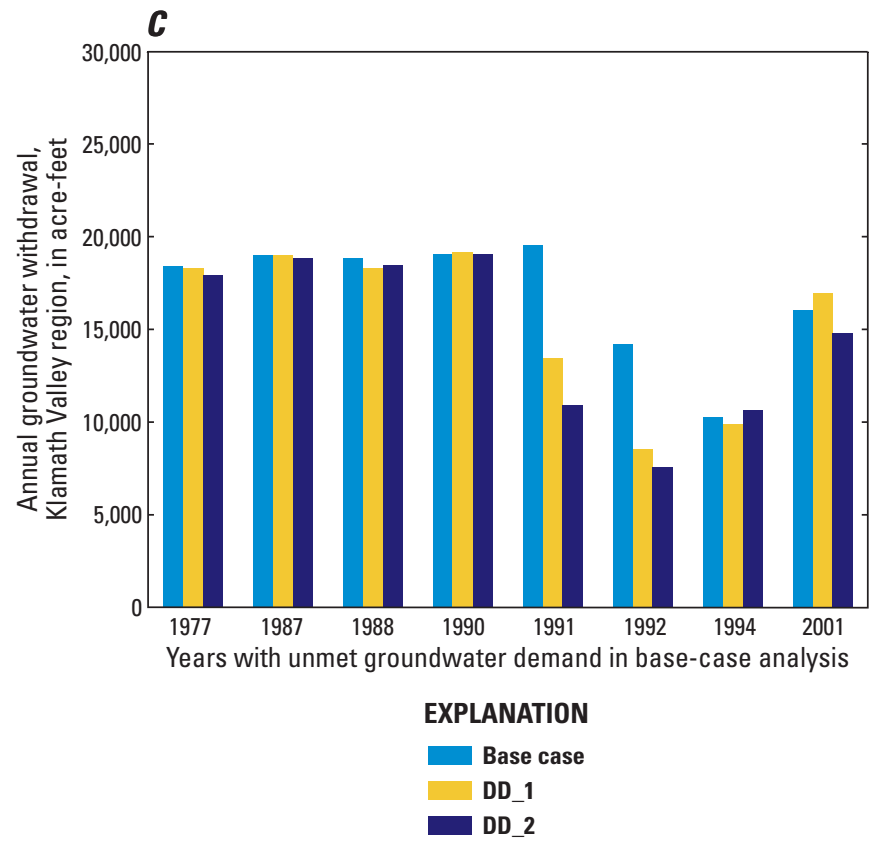

Figure 9. Calculated annual groundwater withdrawals by pumping region for the base-case groundwater-management analysis and analysis of less restrictive drawdown-constraint limits for $(A)$ annual pumping in the southern Tule Lake region; $(B)$ annual pumping in the northern Tule Lake region; and $(C)$ annual pumping in the Klamath Valley region, upper Klamath Basin, Oregon and California, 1970-2004. Results shown are for the water years with unmet groundwater demand in the base-case groundwater-management analysis. Base-case, DD_1, and DD_2 are groundwater-management-model formulations defined in table 1.

Valley regions. Compared with the base-case analysis, the proportion of binding drawdown constraints is higher in the southern Tule Lake region where the largest increases in pumping occur.

The groundwater-management model described in this report maximizes total pumping across the entire network of Project wells and does not include groundwater-demand constraints for the different regions of the Project. For the analysis with less restrictive drawdown constraints, the increased pumping volumes calculated by the groundwatermanagement model occur in the downslope region of the Project, primarily in the southern Tule Lake well group. Because of the Project infrastructure, groundwater withdrawals from the southern Tule Lake wells can be applied only to irrigate lands in the southern Tule Lake or Lower Klamath Lake regions, or delivered to wetlands in the Lower Klamath National Wildlife Refuge. Future analyses of groundwater management for the Project should consider additional constraints to align the geographic distribution of groundwater pumping with water demand. 


\section{Evaluation of Sensitivity to More Restrictive Drawdown Constraints}

An alternative to the evaluation of less restrictive seasonal and year-to-year drawdown limits in the California part of the model could include evaluation of the spatial and temporal distribution of pumping under more restrictive limitations on drawdown. The second sensitivity analysis tests the effect of imposing more restrictive seasonal, yearto-year, and 10-year drawdown limits throughout the Project and adjacent areas, as summarized in table 1 . The base-case optimization model constrains seasonal, year-to-year, and 10 -year drawdowns to be no greater than 25,3 , and $25 \mathrm{ft}$, respectively. In this sensitivity analysis, the drawdown limits for seasonal, year-to-year, and 10-year drawdowns are reduced to 20,2 , and $20 \mathrm{ft}$, respectively, at all drawdown-control sites (this scenario is denoted DD_3 in table 1). As in the analysis of less restrictive drawdown limits in the California part of the model, the revised drawdown limits were selected for illustration purposes.

The groundwater-management model calculated substantial reductions in groundwater withdrawals for the case with more restrictive drawdown limits. Quarterly groundwater withdrawals by pumping region are summarized in table 5 and annual groundwater withdrawals are shown in figure 10. In the base-case analysis, maximum annual withdrawal is about 60,000 acre-ft and the average annual withdrawal in years with unmet groundwater demand is about 54,000 acre-ft. With the more restrictive drawdown limits, the maximum annual withdrawal is about 43,000 acre- $\mathrm{ft}$ and the average withdrawal in years with unmet demand is about 33,000 acre-ft. In addition to the overall reduction in annual withdrawals, there also is a reduction in the number of years in which groundwater demand is satisfied. In the base-case analysis, groundwater demand is met in 14 of the 22 years with nonzero demand and the maximum unmet groundwater demand is about 45,000 acre-ft; with more restrictive drawdown constraints, groundwater demand is met in only 9 of 22 years and the maximum amount of unmet groundwater demand is about 69,000 acre-ft.

Substantial reductions in groundwater withdrawal occur in the southern Tule Lake, northern Tule Lake, and Klamath Valley well groups when the drawdown-constraint limits are more restrictive. The annual pumping volumes for these well groups for the base-case and drawdown scenario DD_3 are shown in figure 11. The pumping volumes shown in figure 11 are for the years with unmet groundwater demand in the base-case analysis (fig. 5 and table 2). The effect of more restrictive drawdown limits is reduced annual pumping in all years (fig. 11). The reduction in annual withdrawal from the

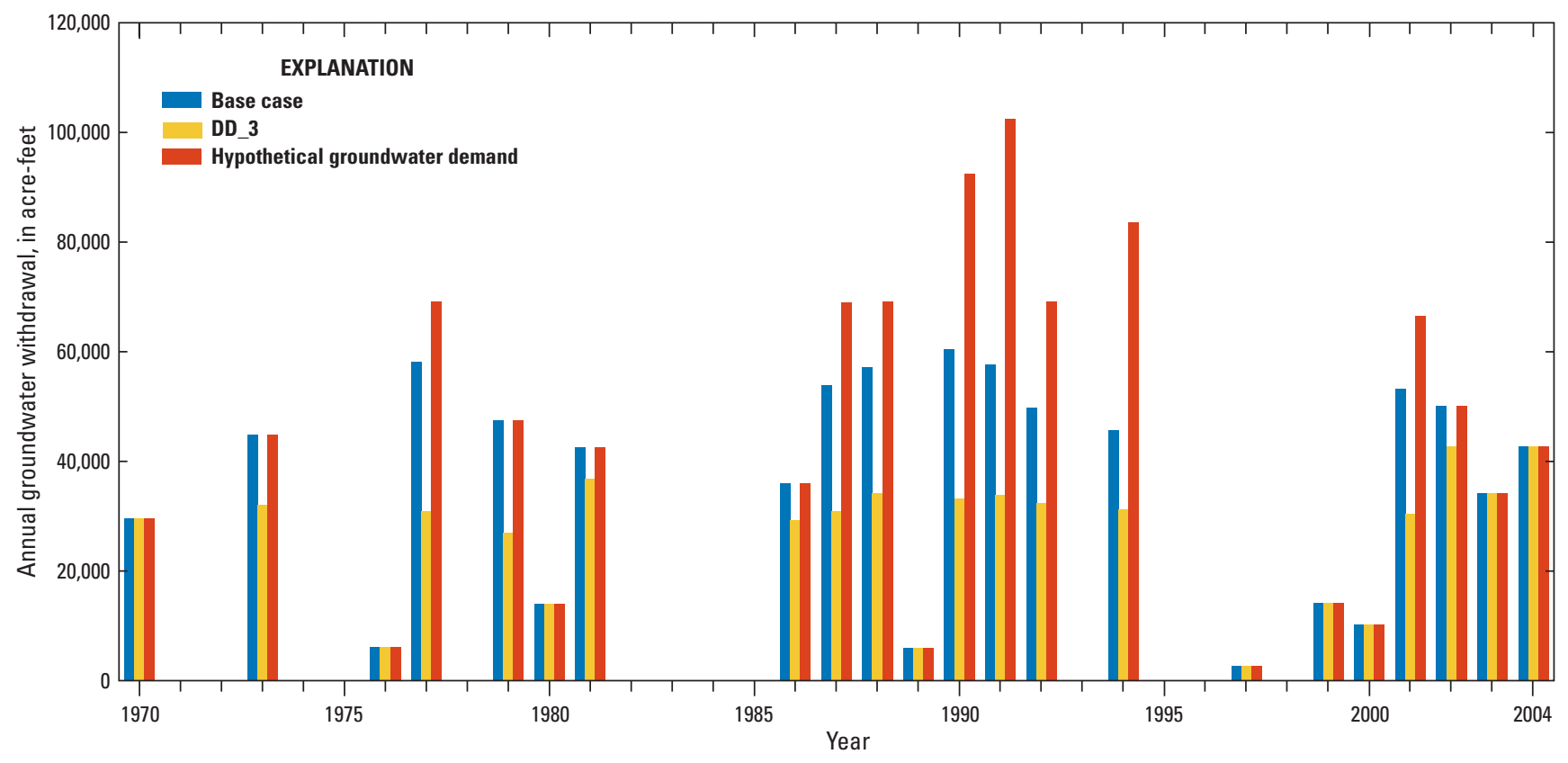

Figure 10. Sensitivity of optimization results to more restrictive drawdown-constraint limits, upper Klamath Basin, Oregon and California, 1970-2004. Base-Case and DD_3 are groundwater-management-model formulations defined in table 1. 
Table 5. Calculated quarterly withdrawals by pumping region and year based on analysis of more restrictive drawdown-constraint limits for scenario DD_3, upper Klamath Basin, Oregon and California, 1970-2004.

[Scenario DD_3. Seasonal drawdown limit is 20 feet, year-to-year drawdown limit is 2 feet, and 10-year drawdown limit is 20 feet at all constraint locations. Shading used to emphasize years in which groundwater demand is not met. All withdrawal volumes are in acre-ft. Abbreviations: KLV, Klamath Valley wells; NTL northern Tule Lake wells; STL, southern Tule Lake wells; LKL, Lower Klamath Lake wells; KLR, Klamath River wells; Q3, third quarter; Q4, fourth quarter]

\begin{tabular}{|c|c|c|c|c|c|c|c|c|c|c|c|}
\hline \multirow{2}{*}{$\begin{array}{c}\text { Pumping } \\
\text { region and } \\
\text { water-year } \\
\text { quarter }\end{array}$} & \multicolumn{11}{|c|}{ Water year } \\
\hline & 1970 & 1973 & 1976 & 1977 & 1979 & 1980 & 1981 & 1986 & 1987 & 1988 & 1989 \\
\hline KLV, Q3 & 2,663 & 8,749 & 440 & 4,521 & 3,148 & 2,644 & 6,604 & 8,754 & 6,307 & 6,155 & 0 \\
\hline Q4 & 7,135 & 6,628 & 1,520 & 4,219 & 4,254 & 5,232 & 4,638 & 6,807 & 5,333 & 5,547 & 1,388 \\
\hline NTL, Q3 & 3,220 & 3,100 & 11 & 3,064 & 2,931 & 578 & 3,666 & 3,232 & 3,557 & 3,560 & 14 \\
\hline STL, Q3 & 9,923 & 5,195 & 0 & 5,650 & 6,141 & 0 & 8,643 & 5,049 & 5,670 & 5,775 & 0 \\
\hline Q4 & 1,110 & 3,965 & 3,334 & 8,486 & 5,427 & 3,634 & 6,914 & 3,284 & 5,232 & 7,507 & 3,835 \\
\hline LKL, Q3 & 342 & 1,020 & 230 & 976 & 1,072 & 285 & 1,002 & 268 & 1,032 & 1,041 & 49 \\
\hline Q4 & 861 & 850 & 110 & 870 & 953 & 92 & 894 & 88 & 578 & 931 & 133 \\
\hline KLR, Q3 & 0 & 504 & 0 & 628 & 585 & 0 & 647 & 0 & 371 & 634 & 0 \\
\hline
\end{tabular}

\begin{tabular}{lrrrrrrrrrrr}
\hline $\begin{array}{c}\text { Pumping } \\
\text { region and } \\
\text { water-year } \\
\text { quarter }\end{array}$ & $\mathbf{1 9 9 0}$ & $\mathbf{1 9 9 1}$ & $\mathbf{1 9 9 2}$ & $\mathbf{1 9 9 4}$ & $\mathbf{1 9 9 7}$ & $\mathbf{1 9 9 9}$ & $\mathbf{2 0 0 0}$ & $\mathbf{2 0 0 1}$ & $\mathbf{2 0 0 2}$ & $\mathbf{2 0 0 3}$ & $\mathbf{2 0 0 4}$ \\
\cline { 2 - 12 } & & & & & & & & \\
\hline KLV, Q3 & 3,786 & 4,250 & 4,811 & 4,108 & 0 & 969 & 448 & 2,750 & 8,089 & 3,664 & 7,870 \\
Q4 & 5,295 & 4,663 & 4,535 & 3,829 & 0 & 3,714 & 2,580 & 3,971 & 8,538 & 6,030 & 8,659 \\
NTL, Q3 & 3,788 & 3,816 & 4,110 & 4,187 & 886 & 1,390 & 508 & 3,050 & 3,807 & 3,436 & 3,893 \\
Q4 & 3,089 & 3,769 & 3,915 & 3,013 & 1,215 & 2,820 & 2,302 & 1,980 & 3,380 & 1,082 & 3,272 \\
STL, Q3 & 8,655 & 8,640 & 8,043 & 7,148 & 0 & 0 & 0 & 7,582 & 8,880 & 6,122 & 7,034 \\
Q4 & 7,217 & 6,723 & 6,522 & 5,903 & 597 & 4,683 & 3,771 & 8,035 & 7,310 & 10,450 & 9,337 \\
LKL, Q3 & 768 & 1,078 & 0 & 987 & 0 & 280 & 245 & 970 & 1,117 & 1,089 & 1,227 \\
Q4 & 0 & 1,017 & 485 & 870 & 0 & 83 & 396 & 991 & 1,007 & 997 & 980 \\
KLR, Q3 & 551 & 0 & 0 & 641 & 0 & 0 & 0 & 625 & 593 & 718 \\
Q4 & 0 & 0 & 0 & 550 & 0 & 223 & 0 & 533 & 0 & 644 \\
$\quad$ Total & 33,149 & 33,956 & 32,421 & 31,236 & 2,698 & 14,162 & 10,250 & 30,487 & 42,721 & 34,228 & 42,812 \\
$\quad$ Demand & 92,415 & 102,466 & 69,198 & 83,686 & 2,698 & 14,162 & 10,250 & 66,463 & 50,056 & 34,228 & 42,812 \\
\hline
\end{tabular}

southern Tule Lake wells is as much as about 13,000 acre- $\mathrm{ft}$ (fig. 11A), the reduction in annual withdrawal from the northern Tule Lake wells is as much as about 9,000 acre-ft (fig. 11B ), and the reduction in annual withdrawal from the Klamath Valley wells is as much as about 11,000 acre-ft (fig. 11C). The application of more restrictive drawdown limits is accompanied by a change in the number of binding drawdown constraints in the groundwater-management model. In the base-case analysis, there are 677 binding drawdown constraints across the entire management period. When the drawdown limits are reduced, the number of binding drawdown constraints increases to 738 , with the increase associated primarily with 4th quarter seasonal drawdown constraints and year-to-year drawdown constraints. 

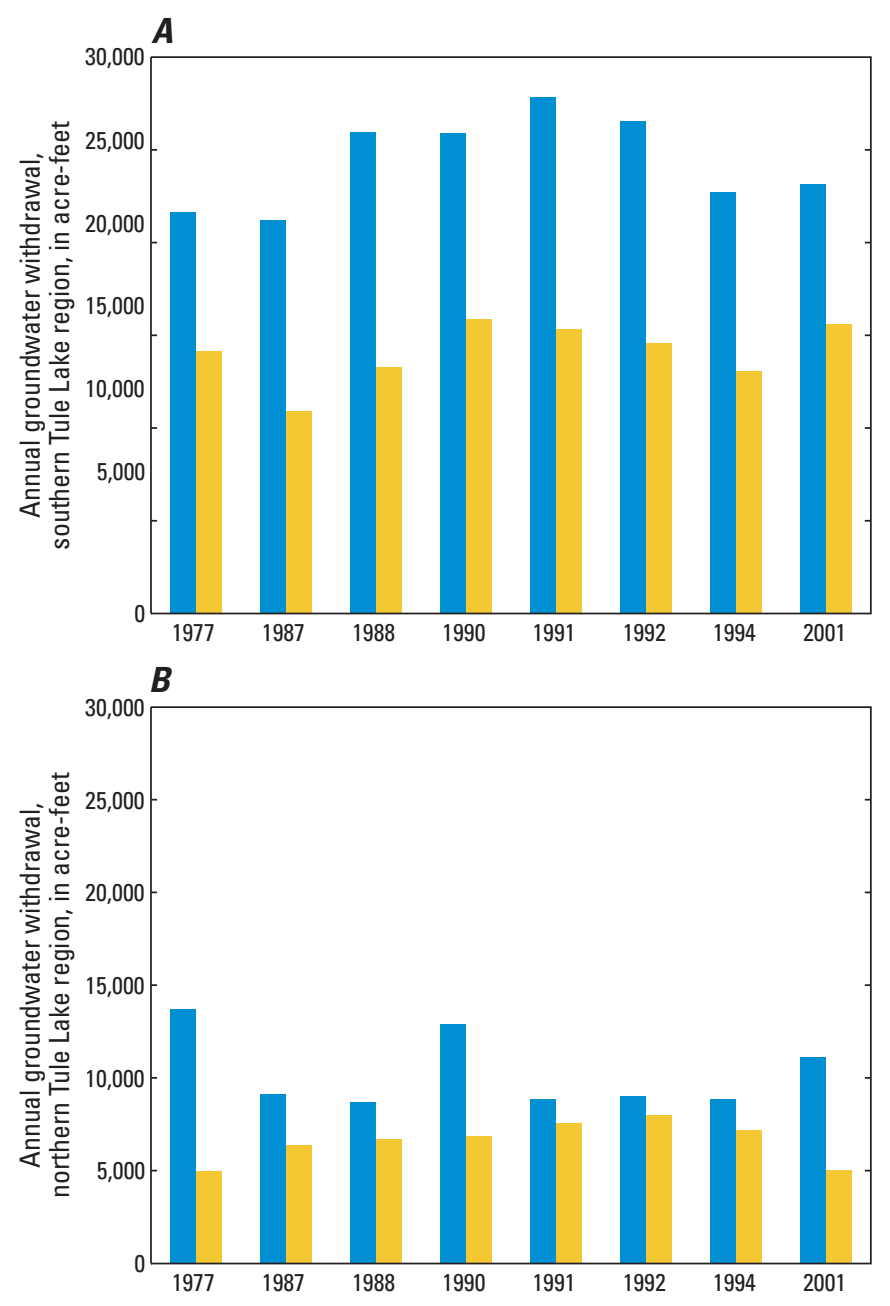

\section{Evaluation of Sensitivity to Changes in the Drain Constraint Limit}

The third sensitivity analysis tests the effect of changing the limit on reductions in groundwater discharge to the Project system of drains. Studies by Burt and Freeman (2003) and Risley and Gannett (2006) highlighted the importance of irrigation return flows to the operation of the Project, which has about $700 \mathrm{mi}$ of drains that collect return flows that can then be recycled for irrigation in downslope areas of the Project or routed to wetlands in the Lower Klamath and Tule Lake National Wildlife Refuges. Irrigation return flows are a substantial, although not quantified, water supply for some downslope irrigation districts and the re-use of return flows significantly increases the Project-wide irrigation efficiency (Burt and Freeman, 2003). The Project infrastructure does not provide detailed measurements of the spatial and temporal patterns of drain discharge; therefore, data are not available to accurately characterize the demand for irrigation return

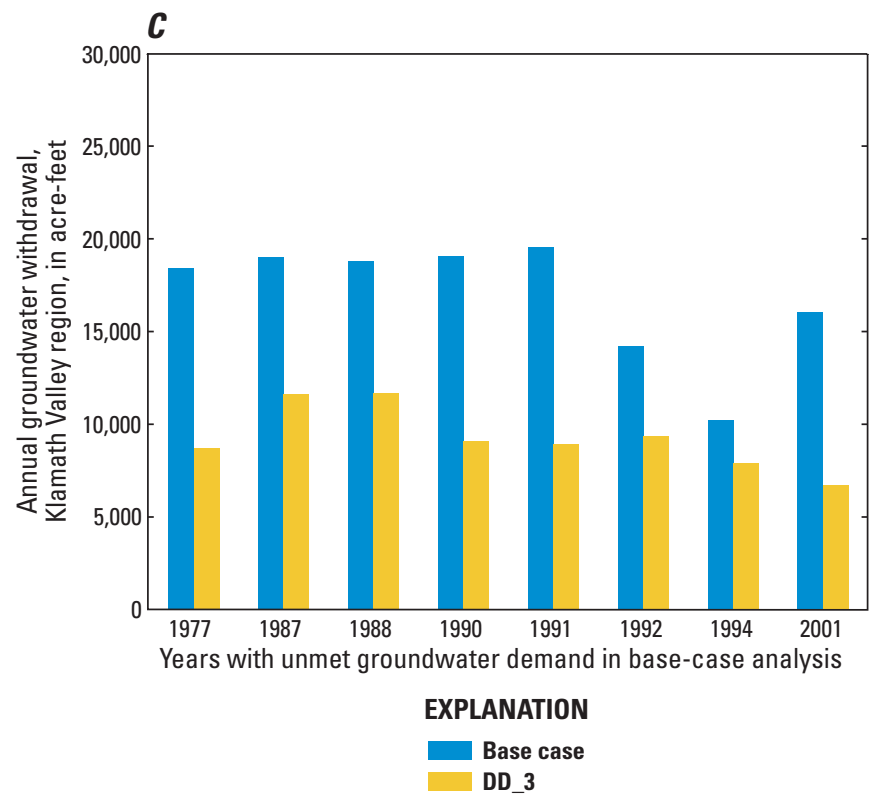

Figure 11. Calculated annual groundwater withdrawals by pumping region for the base-case groundwater-management analysis and analysis of more restrictive drawdown-constraint limits for $(A)$ annual pumping in the southern Tule Lake region; $(B)$ annual pumping in the northern Tule Lake region; and $(C)$ annual pumping in the Klamath Valley region, upper Klamath Basin, Oregon and California, 1970-2004. Results shown are for the years with unmet groundwater demand in the base-case groundwatermanagement analysis. Base-Case and DD_3 are groundwatermanagement-model formulations defined in table 1.

flows or the allowable reduction in drain discharge caused by increased supplemental groundwater pumping. As a result, the limit of the drain-discharge constraint (equation 9), $Q D R_{j, k, \max }$, is uncertain and the evaluation of the effect of different constraint values on the optimal solution is important because changing $Q D R_{j, k, \max }$ could substantially change the amount and distribution of pumping.

A sensitivity analysis was performed to test the effect of changing the limit on reductions in groundwater discharge to the Project system of drains, as summarized in table 1. In the base-case analysis, the allowable reduction in groundwater discharge to drains, $Q D R_{j, k, \max }$, was set to 20 percent of the baseline discharge and was not limiting. Because the drains constraint was not limiting, applying a less restrictive drain constraint (that is, increasing the value of $Q D R_{j, k, \max }$ in equation 9) will not affect the solution of the groundwatermanagement model; however, making the constraint more restrictive (that is, reducing the value of $Q D R_{j, k, \max }$ in equation 9) will eventually cause a reduction in total pumping. 


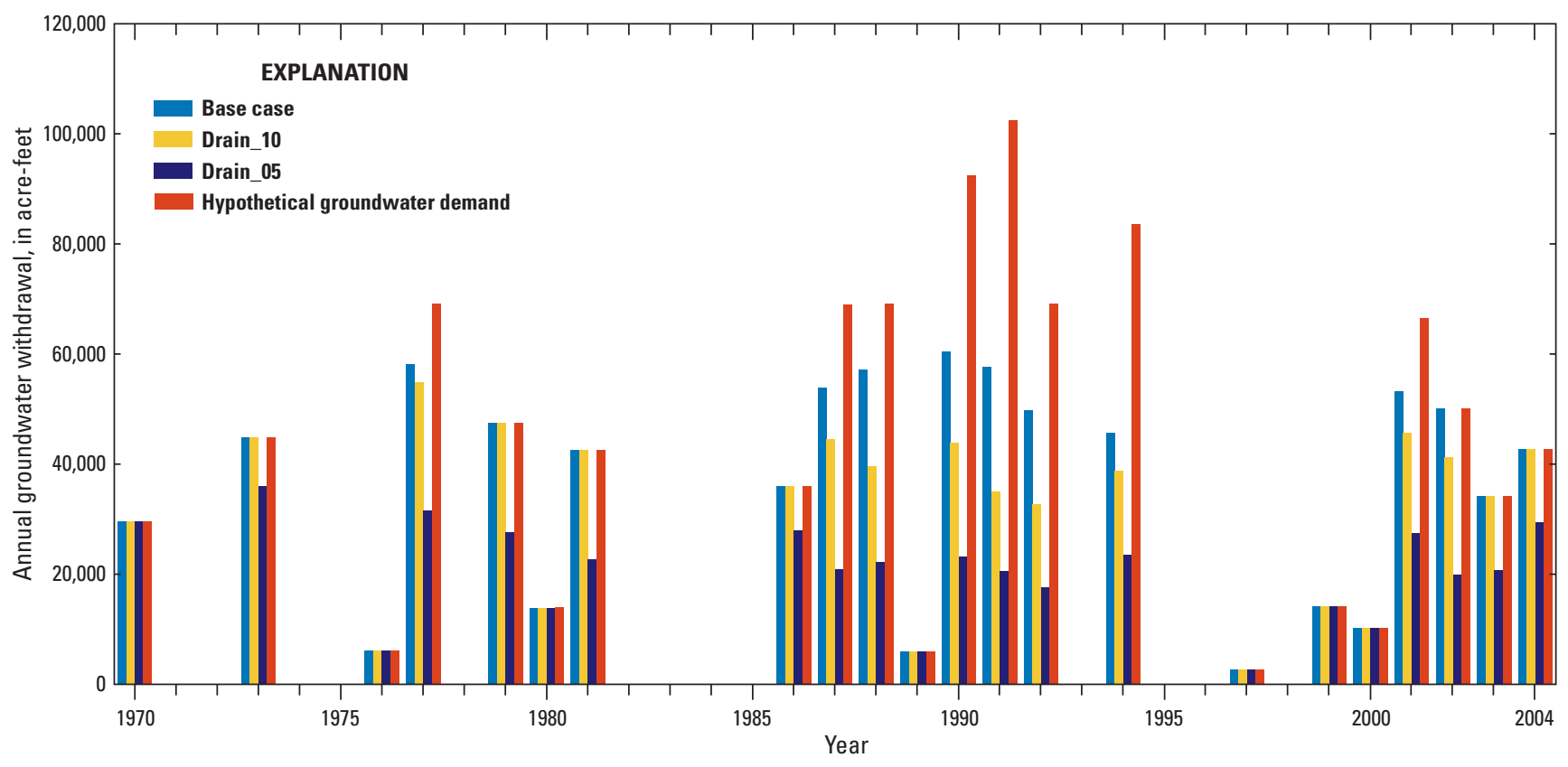

Figure 12. Sensitivity of optimization results to changes in the allowable reduction of groundwater discharge to the Bureau of Reclamation Klamath Irrigation Project drain system, upper Klamath Basin, Oregon and California, 1970-2004. Base-Case, Drain_10, and Drain_05 are groundwater-management-model formulations defined in table 1.

The goal of this two-part sensitivity analysis was to determine the change in pumping volume and distribution associated with a more restrictive drains-discharge constraint. In the first analysis, the drains-discharge constraint limit, $Q D R_{j, k, \max }$, was reduced to 10 percent (this scenario is denoted Drain_10 in table 1). A second analysis further reduced the constraint limit to 5 percent (this scenario is denoted Drain_05 in table 1).

The groundwater-management model calculated substantial reductions in groundwater withdrawals for both analyses. Quarterly groundwater withdrawals by pumping region are summarized in tables 6 and $\underline{7}$, and the trade-off between total annual groundwater pumping and allowable drainflow reduction is summarized in figures 12 and 13 . In the base-case analysis, with $Q D R_{j, k, \max }$ defined based on an allowable reduction of 20 percent, the maximum annual withdrawal is about 60,000 acre-ft and the average annual withdrawal during years with unmet groundwater demand is about 54,000 acre-ft. When the drains constraint limit is set to 10 percent, the maximum annual withdrawal is about 55,000 acre-ft (fig. 12 and table 6) and the average annual withdrawal for years with unmet demand is about 42,000 acre-ft (fig. 13). When the constraint limit is further reduced to 5 percent,

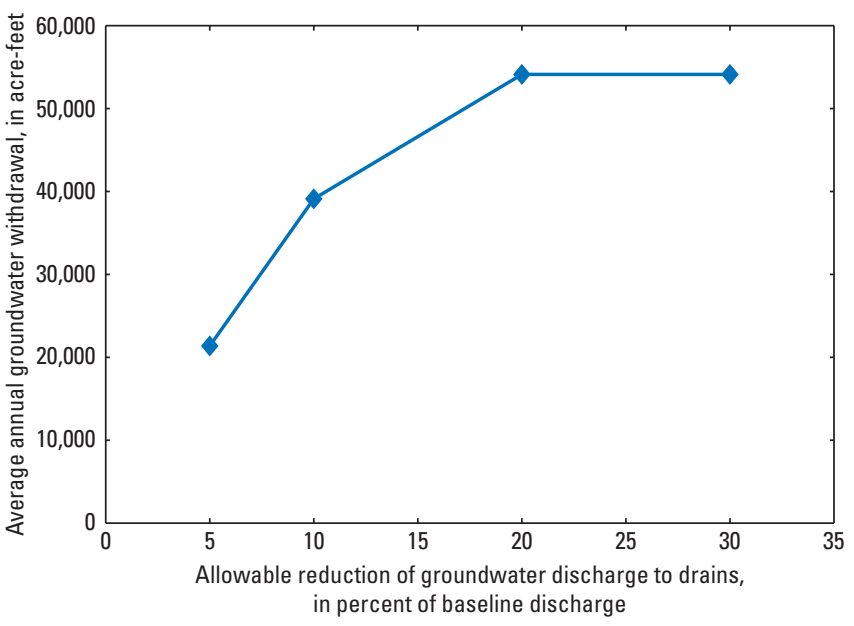

Figure 13. Sensitivity of optimization results to changes in the allowable reduction of groundwater discharge to the Bureau of Reclamation Klamath Irrigation Project drain system. Average annual groundwater withdrawal in years with unmet groundwater demand. 
Table 6. Calculated quarterly withdrawals by pumping region and year based on analysis of more restrictive drain-constraint limit for scenario Drain_10, upper Klamath Basin, Oregon and California, 1970-2004.

[Scenario Drain_10. Drain-Discharge constraint limit is 10 percent. Shading used to emphasize years in which groundwater demand is not met. All withdrawal volumes are in acre-ft. Abbreviations: KLV, Klamath Valley wells; NTL northern Tule Lake wells; STL, southern Tule Lake wells; LKL, Lower Klamath Lake wells; KLR, Klamath River wells; Q3, third quarter; Q4, fourth quarter]

\begin{tabular}{|c|c|c|c|c|c|c|c|c|c|c|c|}
\hline \multirow{2}{*}{$\begin{array}{c}\text { Pumping } \\
\text { region and } \\
\text { water-year } \\
\text { quarter }\end{array}$} & \multicolumn{11}{|c|}{ Water year } \\
\hline & 1970 & 1973 & 1976 & 1977 & 1979 & 1980 & 1981 & 1986 & 1987 & 1988 & 1989 \\
\hline KLV, Q3 & 9,804 & 8,919 & 0 & 10,126 & 10,125 & 5,938 & 10,228 & 9,808 & 10,122 & 6,575 & 3,627 \\
\hline Q4 & 7,908 & 8,996 & 1,474 & 6,324 & 6,770 & 4,119 & 7,669 & 6,930 & 5,883 & 4,742 & 0 \\
\hline NTL, Q3 & 1,171 & 6,614 & 248 & 8,052 & 7,062 & 212 & 4,737 & 4,273 & 4,806 & 6,822 & 3 \\
\hline Q4 & 1,692 & 1,831 & 1,074 & 5,334 & 3,960 & 1,173 & 4,000 & 810 & 2,054 & 3,921 & 0 \\
\hline STL, Q3 & 2,624 & 12,158 & 786 & 14,967 & 14,471 & 2,503 & 9,014 & 10,462 & 11,349 & 9,277 & 2,418 \\
\hline Q4 & 4,574 & 3,161 & 2,521 & 5,686 & 2,779 & 0 & 2,519 & 3,173 & 5,835 & 4,402 & 0 \\
\hline LKL, Q3 & 490 & 1,610 & 0 & 1,593 & 1,680 & 0 & 1,608 & 355 & 1,645 & 1,668 & 0 \\
\hline Q4 & 1,347 & 1,218 & 0 & 1,249 & 123 & 0 & 1,247 & 137 & 1,266 & 1,313 & 0 \\
\hline KLR, Q3 & 0 & 443 & 0 & 799 & 550 & 0 & 820 & 0 & 843 & 827 & 0 \\
\hline Q4 & 0 & 0 & 0 & 708 & 0 & 0 & 735 & 0 & 738 & 15 & 0 \\
\hline Total & 29,610 & 44,949 & 6,103 & 54,838 & 47,521 & 13,945 & 42,577 & 35,948 & 44,541 & 39,562 & 6,049 \\
\hline Demand & 29,610 & 44,949 & 6,103 & 69,198 & 47,521 & 13,945 & 42,577 & 35,948 & 68,945 & 69,162 & 6,049 \\
\hline
\end{tabular}

\begin{tabular}{|c|c|c|c|c|c|c|c|c|c|c|c|}
\hline \multirow{2}{*}{$\begin{array}{l}\text { Pumping } \\
\text { region and } \\
\text { water-year } \\
\text { quarter }\end{array}$} & \multicolumn{11}{|c|}{ Water year } \\
\hline & 1990 & 1991 & 1992 & 1994 & 1997 & 1999 & 2000 & 2001 & 2002 & 2003 & 2004 \\
\hline KLV, Q3 & 8,362 & 5,187 & 4,292 & 4,246 & 1,025 & 7,657 & 2,091 & 7,272 & 5,066 & 4,106 & 4,090 \\
\hline Q4 & 4,308 & 4,427 & 4,035 & 3,944 & 1,174 & 693 & 1,335 & 5,080 & 4,179 & 3,696 & 5,090 \\
\hline NTL, Q3 & 6,870 & 4,652 & 5,226 & 4,980 & 257 & 850 & 86 & 6,442 & 7,030 & 7,192 & 8,543 \\
\hline Q4 & 3,901 & 3,782 & 4,000 & 3,790 & 242 & 440 & 3,299 & 4,407 & 7,574 & 6,116 & 5,686 \\
\hline STL, Q3 & 10,555 & 9,245 & 8,892 & 10,838 & 0 & 3,733 & 2,884 & 13,442 & 10,761 & 8,683 & 8,854 \\
\hline Q4 & 5,971 & 4,108 & 3,652 & 7,183 & 0 & 789 & 555 & 4,764 & 2,670 & 805 & 7,703 \\
\hline LKL, Q3 & 1,615 & 1,385 & 1,295 & 1,247 & 0 & 0 & 0 & 1,590 & 1,742 & 393 & 379 \\
\hline Q4 & 1,262 & 1,410 & 1,192 & 1,115 & 0 & 0 & 0 & 1,228 & 1,391 & 1,532 & 1,472 \\
\hline KLR, Q3 & 829 & 892 & 69 & 815 & 0 & 0 & 0 & 797 & 784 & 890 & 865 \\
\hline Q4 & 279 & 0 & 0 & 719 & 0 & 0 & 0 & 701 & 0 & 815 & 130 \\
\hline Total & 43,952 & 35,088 & 32,653 & 38,877 & 2,698 & 14,162 & 10,250 & 45,723 & 41,197 & 34,228 & 42,812 \\
\hline Demand & 92,415 & 102,466 & 69,198 & 83,686 & 2,698 & 14,162 & 10,250 & 66,463 & 50,056 & 34,228 & 42,812 \\
\hline
\end{tabular}

the maximum annual withdrawal is about 36,000 acre-ft (fig. 12 and table 7) and the average annual withdrawal for years with unmet demand is about 25,000 acre-ft (fig. 13). In addition to the overall reduced annual withdrawals associated with the more restrictive drain-discharge-constraint limits, the number of years when the groundwater demand can be met with the current configuration of wells also is reduced. In the base-case analysis, groundwater demand is met in 14 of the 22 years with non-zero demand and the maximum unmet groundwater demand is about 45,000 acre-ft. When the drains constraint limit is set to 10 percent, groundwater demand is met in 13 of 22 years and the maximum groundwater deficit is about 67,000 acre-ft; when the constraint limit is set to 5 percent, groundwater demand is met in 7 of 22 years and the maximum groundwater deficit is about 82,000 acre-ft. 
Table 7. Calculated quarterly withdrawals by pumping region and year based on analysis of more restrictive drain-constraint limit for scenario Drain_05, upper Klamath Basin, Oregon and California, 1970-2004.

[Scenario Drain_05. Drain-Discharge constraint limit is 5 percent. Shading used to emphasize years in which groundwater demand is not met. All withdrawal volumes are in acre-ft. Abbreviations: KLV, Klamath Valley wells; NTL northern Tule Lake wells; STL, southern Tule Lake wells; LKL, Lower Klamath Lake wells; KLR, Klamath River wells; Q3, third quarter; Q4, fourth quarter]w

\begin{tabular}{|c|c|c|c|c|c|c|c|c|c|c|c|}
\hline $\begin{array}{l}\text { Pumping } \\
\text { region and } \\
\text { water-year } \\
\text { quarter }\end{array}$ & \multicolumn{11}{|c|}{ Water year } \\
\hline KLV, Q3 & 9,596 & 4,603 & 4,044 & 4,565 & 4,852 & 3,900 & 4,413 & 7,533 & 4,610 & 4,843 & 2,891 \\
\hline Q4 & 6,583 & 2,935 & 680 & 4,115 & 3,366 & 2,478 & 3,912 & 3,929 & 3,852 & 4,443 & 399 \\
\hline NTL, Q3 & 746 & 6,992 & 7 & 6,884 & 6,832 & 0 & 3,030 & 1,959 & 444 & 444 & 6 \\
\hline STL, Q3 & 7,191 & 12,319 & 1,370 & 9,362 & 7,033 & 3,482 & 5,622 & 8,936 & 6,379 & 6,277 & 1,480 \\
\hline Q4 & 2,425 & 1,620 & 0 & 1,059 & 634 & 3,356 & 577 & 2,933 & 3,164 & 548 & 1,273 \\
\hline LKL, Q3 & 1,106 & 1,605 & 0 & 1,366 & 1,420 & 377 & 357 & 355 & 357 & 710 & 0 \\
\hline Q4 & 1,080 & 126 & 0 & 142 & 122 & 0 & 124 & 764 & 122 & 130 & 0 \\
\hline KLR, Q3 & 0 & 634 & 0 & 800 & 875 & 352 & 823 & 319 & 845 & 827 & 0 \\
\hline
\end{tabular}

\begin{tabular}{|c|c|c|c|c|c|c|c|c|c|c|c|}
\hline $\begin{array}{c}\text { Pumping } \\
\text { region and } \\
\text { water-year } \\
\text { quarter }\end{array}$ & \multicolumn{11}{|c|}{ Water year } \\
\hline KLV, Q3 & 4,877 & 4,976 & 4,126 & 3,289 & 2,698 & 6,339 & 4,599 & 4,793 & 4,123 & 4,136 & 4,148 \\
\hline Q4 & 4,309 & 3,913 & 4,019 & 3,370 & 0 & 3,528 & 1,114 & 4,123 & 3,715 & 3,934 & 2,780 \\
\hline NTL, Q3 & 1,804 & 2,551 & 2,939 & 4,698 & 0 & 135 & 10 & 3,220 & 1,527 & 6,265 & 8,809 \\
\hline Q4 & 678 & 0 & 0 & 83 & 0 & 0 & 381 & 1,820 & 946 & 0 & 528 \\
\hline LKL, Q3 & 1,611 & 1,379 & 1,295 & 1,244 & 0 & 0 & 0 & 1,590 & 1,742 & 390 & 378 \\
\hline Q4 & 1,256 & 1,412 & 95 & 1,111 & 0 & 0 & 0 & 1,228 & 1,390 & 194 & 168 \\
\hline KLR, Q3 & 828 & 67 & 0 & 813 & 0 & 0 & 0 & 798 & 829 & 877 & 860 \\
\hline Q4 & 216 & 0 & 0 & 719 & 0 & 0 & 0 & 702 & 0 & 0 & 88 \\
\hline
\end{tabular}

The trade-offs between calculated annual withdrawal and the drain-constraint limit for the southern Tule Lake, northern Tule Lake, and Klamath Valley well groups (for the years with unmet groundwater demand in the base-case analysis) are shown in figure 14. The trade-offs summarized in figure 14 indicate that the largest reductions in groundwater withdrawal, in comparison to the base-case analysis, occur in the southern Tule lake well group. These wells generally have the highest annual pumping volumes in the base-case analysis and have the largest effects on groundwater discharge to drains. When the drains-constraint limit is set to 10 percent, the reduction in annual withdrawal from the southern Tule Lake wells is as much as about 14,000 acre-ft, and when the drains constraint limit is set to 5 percent, the reduction in annual withdrawal from these wells is as much as about 24,000 acre-ft (fig. 14A). There also were reductions in annual withdrawals at the wells in the northern Tule Lake and Klamath Valley well groups. With the drains-constraint limit set to 10 percent, annual withdrawals from the northern Tule Lake 

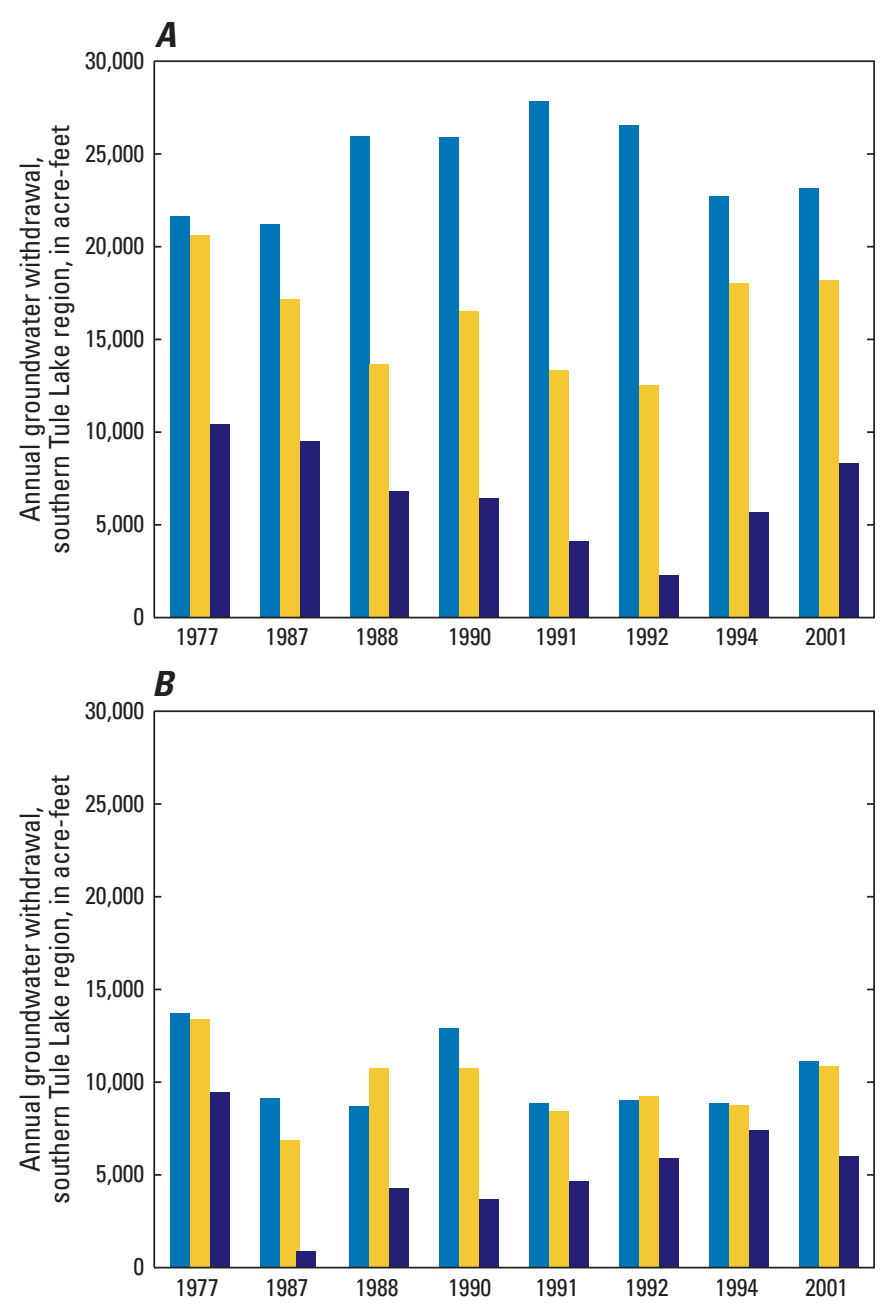

well group were reduced by as much as 2,000 acre-ft (fig. 14B) and annual withdrawals at the Klamath Valley well group were reduced by as much as 10,000 acre-ft (fig. 14C). When the drainsconstraint limit was reduced to 5 percent, annual withdrawals at the northern Tule Lake wells were reduced by as much as 9,000 acre-ft (fig. 14B) and withdrawals at the Klamath Valley wells were reduced by as much as 11,000 acre-ft (fig. 14C).

The relative changes in groundwater withdrawal compared to the base-case analysis are determined by the more restrictive limits on reductions of groundwater discharge to the Project drain system. When the drains-constraint limit is reduced to 10 percent, the drain-discharge constraint is binding in 12 of the 22 years with non-zero groundwater demand. With the drains-constraint limit reduced to 5 percent, the drain-discharge constraint is binding in 18 of the 22 years with non-zero groundwater demand, including all years with unmet groundwater demand. The increase in the number of binding drain-discharge constraints is accompanied by a reduction in the number of binding seasonal and yearto-year drawdown constraints, which is a result of the

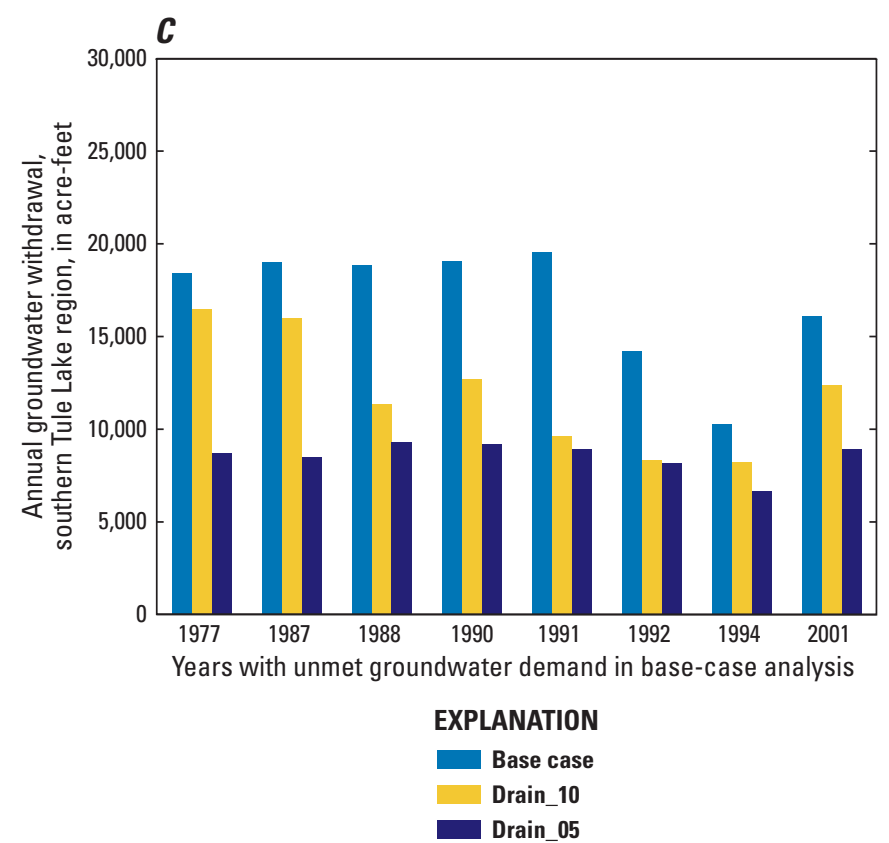

Figure 14. Calculated annual groundwater withdrawals by pumping region for the base-case groundwater-management analysis and analyses of alternative drain-discharge-constraint limits for $(A)$ annual pumping in the southern Tule Lake region; $(B)$ annual pumping in the northern Tule Lake region, and $(C)$ annual pumping in the Klamath Valley region, upper Klamath Basin, Oregon and California, 1970-2004. Results shown are for the years with unmet groundwater demand in the base-case groundwatermanagement analysis. Base-case, Drain_10, and Drain_05 are groundwater-management-model formulations defined in table 1.

overall reduction in pumping volumes associated with more restrictive drain-discharge-constraint limits. When the drainsdischarge constraint limit is set to 10 percent, there are a total of 554 binding seasonal drawdown constraints and 75 binding year-to-year drawdown constraints; and with the drains-discharge limit set to 5 percent, the number of binding seasonal drawdown constraints is 375 and the number of binding year-to-year drawdown constraints is 51 .

The results of the drains-constraint sensitivity analysis summarized in figure 13 are consistent with the results presented in Gannett and others (2012) and highlight the important hydrologic relation between groundwater pumping and irrigation return flows. The optimization model indicates the need for substantial reductions in supplemental on-Project pumping if the drains-constraint limit in equation 9 is reduced to less than 20 percent (assuming that all other constraint limits are maintained at their base-case values). Reducing the uncertainty associated with the drain-constraint limit would provide a more accurate prediction of the capacity for groundwater development within the Project. 


\section{Evaluation of Trade-offs Associated with Increased Pumping Capacity}

In the base-case analysis, the network of Project wells does not meet expected Project groundwater demand in 8 of 22 years with hypothetical surface-water deficits. This is partly due to the geographic distribution and pumping capacities of the on-Project wells. One option for potentially increasing annual pumping volumes is to increase the available pumping capacity. A sensitivity analysis was done to assess the potential value of additional pumping capacity at existing decision wells. This was done by increasing the well capacity limit, $Q w_{i, \max }$, and resolving the optimization problem. To ensure that well capacity limits do not control the optimization results, $Q w_{i, \text { max }}$ was increased to $100 \mathrm{ft}^{3} / \mathrm{s}$ for each decision variable. This approach allows the groundwater management model to account for increased pumping capacity at existing decision wells without increasing the computational demand of the optimization problem. A broader analysis that also expands the geographic coverage of the network of managed wells would provide a more comprehensive understanding of the potential effect of increased pumping capacity. The feasibility of increasing pumping capacities at existing wells or installing new wells was not considered in this analysis. Additionally, the regulatory controls that might limit increased groundwater pumping in Oregon were not addressed in this analysis.

Total annual withdrawal amounts calculated for the modified optimization model are summarized in figure 15 and quarterly pumping amounts by geographic region are summarized in table 8 . The analysis of increased pumping capacity indicates the potential for substantial increases in annual pumping volumes. The maximum annual groundwater withdrawal is about 84,000 acre- $\mathrm{ft}$ (compared to 60,000 acre- $\mathrm{ft}$ in the base-case analysis) and groundwater demand is met in 17 of 22 years (compared to 14 of 22 years in the base-case analysis). The average annual withdrawal in years with unmet groundwater demand is about 70,000 acre-ft (compared to 54,000 acre-ft in the base-case analysis) and the maximum groundwater deficit is about 27,000 acre-ft (compared to 45,000 acre-ft in the base-case analysis).

Annual pumping amounts for the southern Tule Lake, northern Tule Lake, and Klamath Valley well groups for the base-case analysis and the analysis with increased pumping capacity (for the years with unmet groundwater demand in the base-case analysis) are shown in figure 16. Compared to the withdrawals calculated for the base-case analysis, the amounts pumped in the Klamath Valley region are substantially increased when pumping capacity is increased.

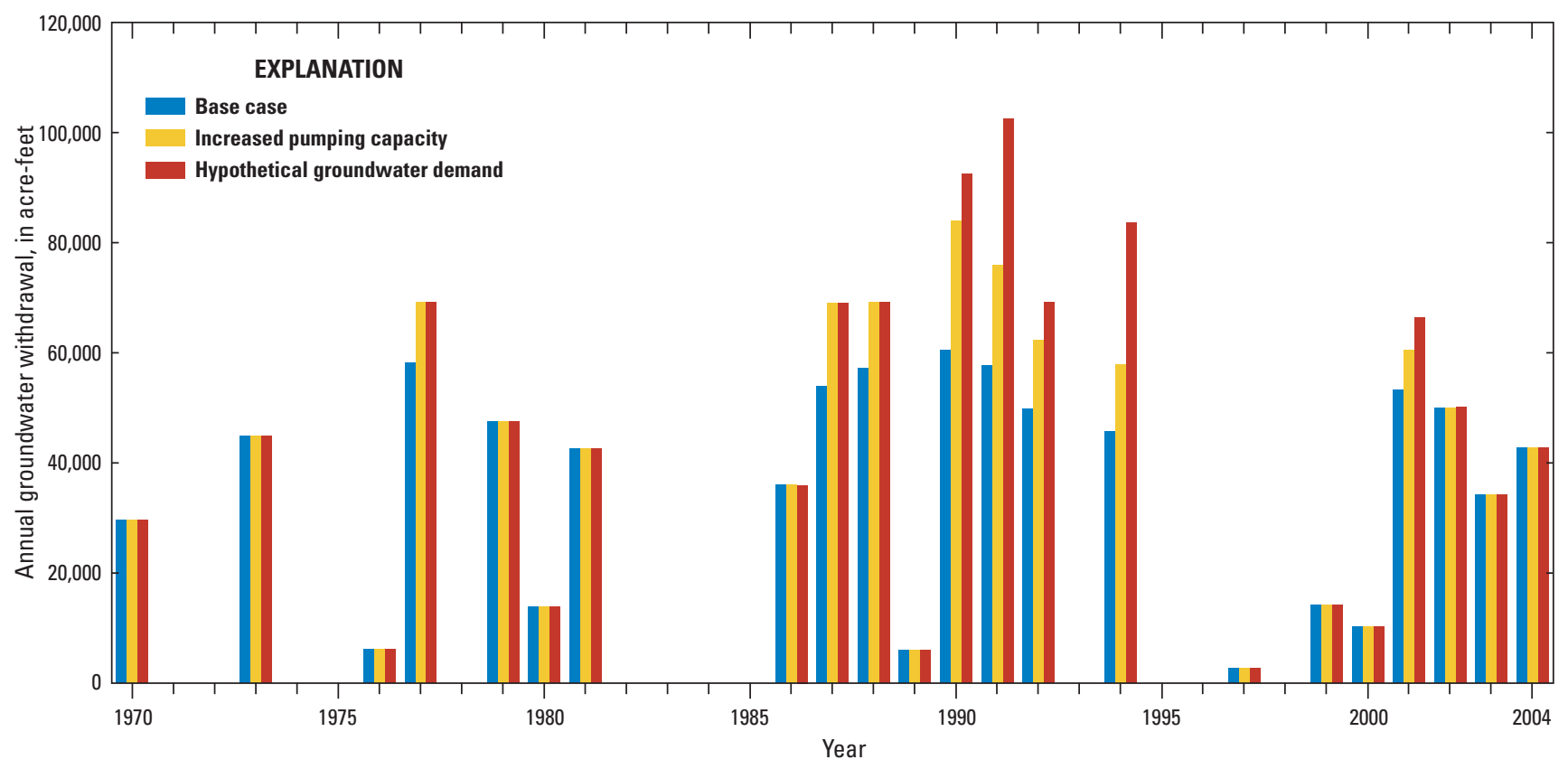

Figure 15. Sensitivity of optimization results to additional pumping capacity at network of wells serving the Bureau of Reclamation Klamath Irrigation Project, upper Klamath Basin, Oregon and California, 1970-2004. Base-case and Increased pumping capacity are groundwater-management-model formulations defined in table 1. 
Table 8. Calculated quarterly withdrawals by pumping region and year based on analysis of additional pumping capacity, upper Klamath Basin, Oregon and California, 1970-2004.

[Shading used to emphasize years in which groundwater demand is not met. All withdrawal volumes are in acre-ft. Abbreviations: KLV, Klamath Valley wells; NTL northern Tule Lake wells; STL, southern Tule Lake wells; LKL, Lower Klamath Lake wells; KLR, Klamath River wells; Q3, third quarter; Q4, fourth quarter, upper Klamath Basin, Oregon and California, 1970-2004]

\begin{tabular}{|c|c|c|c|c|c|c|c|c|c|c|c|}
\hline \multirow{2}{*}{$\begin{array}{c}\text { Pumping } \\
\text { region and } \\
\text { water-year } \\
\text { quarter }\end{array}$} & \multicolumn{11}{|c|}{ Water year } \\
\hline & 1970 & 1973 & 1976 & 1977 & 1979 & 1980 & 1981 & 1986 & 1987 & 1988 & 1989 \\
\hline KLV, Q3 & 11,054 & 21,219 & 700 & 22,626 & 19,670 & 2,787 & 8,120 & 10,047 & 13,454 & 14,260 & 0 \\
\hline Q4 & 15,762 & 13,059 & 818 & 18,403 & 6,482 & 2,336 & 22,203 & 11,470 & 23,919 & 22,287 & 1,199 \\
\hline NTL, Q3 & 391 & 1,839 & 0 & 2,635 & 1,231 & 0 & 917 & 915 & 3,681 & 3,357 & 269 \\
\hline Q4 & 739 & 315 & 399 & 1,593 & 1,390 & 0 & 777 & 1,283 & 2,656 & 2,975 & 610 \\
\hline STL, Q3 & 0 & 3,695 & 554 & 11,856 & 10,606 & 4,731 & 6,614 & 9,285 & 10,184 & 14,210 & 0 \\
\hline Q4 & 0 & 3,255 & 3,632 & 8,304 & 6,856 & 3,630 & 0 & 2,948 & 10,691 & 11,415 & 3,971 \\
\hline LKL, Q3 & 560 & 355 & 0 & 1,233 & 0 & 461 & 1,260 & 0 & 1,642 & 360 & 0 \\
\hline Q4 & 1,102 & 1,182 & 0 & 1,109 & 1,286 & 0 & 1,133 & 0 & 1,142 & 125 & 0 \\
\hline KLR, Q3 & 0 & 30 & 0 & 799 & 0 & 0 & 820 & 0 & 842 & 173 & 0 \\
\hline Q4 & 0 & 0 & 0 & 640 & 0 & 0 & 734 & 0 & 734 & 0 & 0 \\
\hline Total & 29,610 & 44,949 & 6,103 & 69,198 & 47,521 & 13,945 & 42,577 & 35,948 & 68,945 & 69,162 & 6,049 \\
\hline Demand & 29,610 & 44,949 & 6,103 & 69,198 & 47,521 & 13,945 & 42,577 & 35,948 & 68,945 & 69,162 & 6,049 \\
\hline
\end{tabular}

\begin{tabular}{|c|c|c|c|c|c|c|c|c|c|c|c|}
\hline \multirow{2}{*}{$\begin{array}{l}\text { Pumping } \\
\text { region and } \\
\text { water-year } \\
\text { quarter }\end{array}$} & \multicolumn{11}{|c|}{ Water year } \\
\hline & 1990 & 1991 & 1992 & 1994 & 1997 & 1999 & 2000 & 2001 & 2002 & 2003 & 2004 \\
\hline KLV, Q3 & 25,409 & 26,353 & 15,331 & 7,442 & 0 & 703 & 728 & 11,754 & 4,036 & 2,795 & 12,774 \\
\hline Q4 & 17,586 & 15,544 & 14,224 & 15,367 & 0 & 848 & 2,362 & 9,841 & 14,516 & 11,479 & 5,062 \\
\hline NTL, Q3 & 7,666 & 4,683 & 5,512 & 5,325 & 1,025 & 2,598 & 227 & 7,948 & 5,544 & 8,258 & 3,438 \\
\hline STL, Q3 & 15,207 & 15,665 & 13,081 & 11,417 & 0 & 356 & 0 & 14,449 & 16,075 & 1,518 & 8,530 \\
\hline Q4 & 10,570 & 6,359 & 9,650 & 10,571 & 0 & 5,727 & 5,215 & 8,955 & 5,615 & 0 & 8,594 \\
\hline LKL, Q3 & 1,612 & 1,350 & 0 & 1,245 & 0 & 0 & 0 & 1,591 & 374 & 1,327 & 0 \\
\hline Q4 & 1,259 & 1,370 & 0 & 1,110 & 0 & 0 & 0 & 1,231 & 149 & 1,480 & 244 \\
\hline KLR, Q3 & 310 & 0 & 0 & 815 & 0 & 793 & 0 & 0 & 546 & 887 & 0 \\
\hline
\end{tabular}

Calculated withdrawals from the Klamath Valley well group increase by amounts as much as about 24,000 acre- $\mathrm{ft}$ (fig. 16C). The increased pumping at the Klamath Valley wells is accompanied by a reduction in pumping in most years at the southern Tule Lake and northern Tule Lake wells. This occurs for two reasons. First, the increase in total annual pumping during the extended drought period from 1987 to 1994 resulted in binding drain-discharge constraints in 1991, 1992 and 1994. To balance the increased pumping by the Klamath Valley well group and its effect on groundwater discharge to the Project drains, groundwater withdrawals from the southern Tule Lake well group were reduced by as much as 6,000 acre-ft (fig. 16A). Second, in the revised scenario with increased pumping capacity, the optimization model identified a pumping strategy that meets groundwater demand in 1977, 1987, and 1988. As a result, groundwater withdrawals from the northern Tule Lake wells are reduced by as much as 9,000 acre-ft (fig. 16B ) when compared to the base-case analysis. 

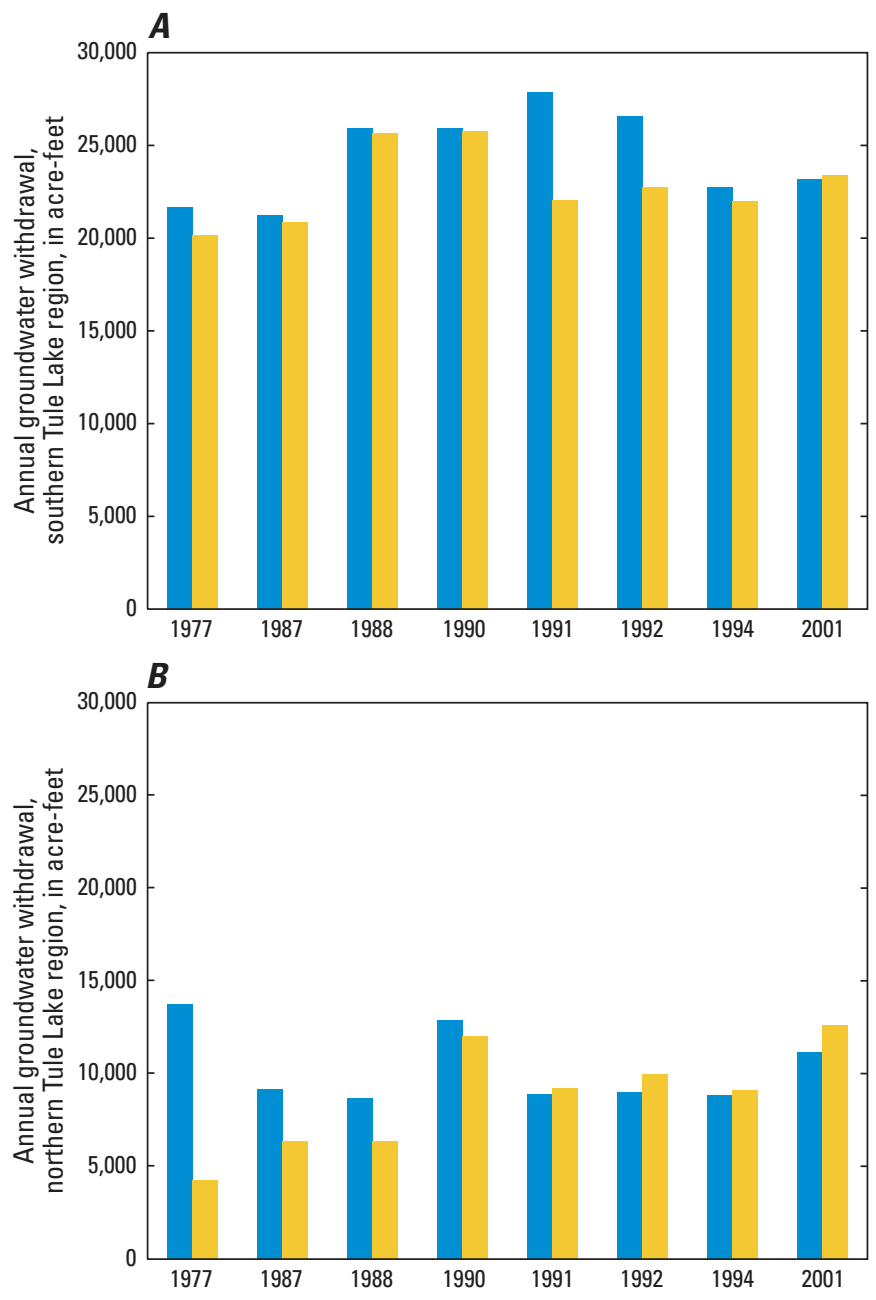

In addition to the binding drain-discharge constraints, the calculated withdrawals also are limited by drawdown constraints. As in the base-case analysis, the limiting drawdown constraints are associated with seasonal, year-toyear, and 10-year drawdowns. The number and geographic distribution of binding drawdown constraints is similar to the base-case results, the primary difference being the addition of binding seasonal and year-to-year drawdown constraints at the Klamath Valley wells with increased pumping.

\section{Evaluation of Trade-offs Associated with Reduced Background Pumping}

Background pumping is included in the groundwatermanagement model and varies in response to changing climate conditions as off-Project irrigators increase groundwater pumping during drought periods to meet their increased irrigation needs. These background stresses can affect groundwater levels at drawdown-constraint locations. As a result, the optimized withdrawals calculated

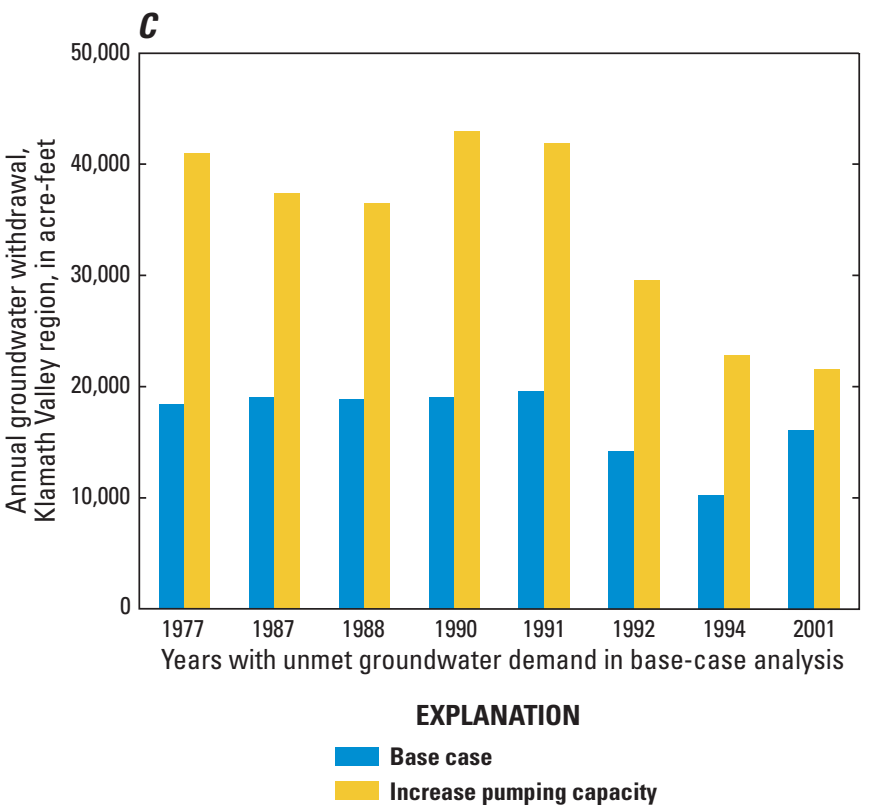

Figure 16. Calculated annual groundwater withdrawals by pumping region for the base-case groundwater-management analysis and analysis of increased pumping capacity for $(A)$ annual pumping in the southern Tule Lake region; $(B)$ annual pumping in the northern Tule Lake region; and $(C)$ annual pumping in the Klamath Valley region, upper Klamath Basin, Oregon and California, 1970-2004. Results are shown for the years with unmet groundwater demand in the base-case groundwater-management analysis. Base-case and Increase pumping capacity are groundwater-management-model formulations defined in table 1.

by the groundwater-management model are affected by the distribution and amounts of background pumping in the vicinity of the Project. This final sensitivity analysis evaluated the trade-off between reduced background pumping and increased withdrawal at wells serving the Project. The approach used was to remove background pumping at locations that are likely to affect groundwater levels at drawdown-constraint locations that control the groundwatermanagement model solution. The optimization model (equations 1-11) was then re-solved to determine the increase in the calculated, on-Project groundwater pumping that results from the removal of background, off-Project groundwater pumping. The example described in this study is for illustration purposes and does not address the broader issues associated with acquiring the rights to off-Project groundwater pumping.

In the base-case groundwater-management analysis, the calculated withdrawals were limited only by drawdown constraints. In order to test the effectiveness of removing offProject groundwater pumping, background pumping located 
within one model cell of any binding drawdown-constraint location (fig. 7) was removed in all years of the groundwater simulation model. The groundwater-management model was then resolved. The total background pumping that was removed from the model is summarized in figure 17. The results of the updated groundwater-management model are summarized in figure 18 and table 9 . The years with unmet groundwater demand are unchanged from the base-case analysis. The maximum annual groundwater withdrawal is about 70,000 acre- $\mathrm{ft}$, the average annual pumping for those years with unmet groundwater demand is about 65,000 acre-ft, and the maximum groundwater deficit is about 32,000 acre-ft. The average annual pumping in years with unmet groundwater demand increases by about 11,000 acre-ft compared with the base-case analysis. Because the average amount of background pumping removed in the years with unmet groundwater demand is about 15,000 acre-ft, the model results indicate the increase in on-Project pumping is approximately 73 percent of the background pumping that was removed from the model. Further analyses are needed to determine if these on-Project pumping gains are applicable if the removal of offProject pumping follows a different scheme.

Table 9. Calculated quarterly withdrawals by pumping region and year based on analysis of removal of selected background pumping, upper Klamath Basin, Oregon and California, 1970-2004.

[Shading used to emphasize years in which groundwater demand is not met. All withdrawal volumes are in acre-ft. Abbreviations: KLV, Klamath Valley wells; NTL northern Tule Lake wells; STL, southern Tule Lake wells; LKL, Lower Klamath Lake wells; KLR, Klamath River wells; Q3, third quarter; Q4, fourth quarter]

\begin{tabular}{|c|c|c|c|c|c|c|c|c|c|c|c|}
\hline \multirow{2}{*}{$\begin{array}{c}\text { Pumping } \\
\text { region and } \\
\text { water-year } \\
\text { quarter }\end{array}$} & \multicolumn{11}{|c|}{ Water year } \\
\hline & 1970 & 1973 & 1976 & 1977 & 1979 & 1980 & 1981 & 1986 & 1987 & 1988 & 1989 \\
\hline KLV, Q3 & 2,916 & 7,073 & 0 & 10,123 & 8,527 & 0 & 309 & 7,865 & 10,226 & 10,307 & 0 \\
\hline Q4 & 4,986 & 7,312 & 1,337 & 9,323 & 7,353 & 0 & 3,240 & 9,111 & 9,476 & 9,592 & 391 \\
\hline NTL, Q3 & 8,075 & 8,439 & 0 & 9,662 & 5,519 & 202 & 6,162 & 4,352 & 10,091 & 9,998 & 0 \\
\hline Q4 & 3,804 & 6,353 & 1,348 & 6,028 & 5,387 & 1,269 & 6,139 & 3,987 & 7,107 & 8,378 & 618 \\
\hline STL, Q3 & 4,832 & 5,166 & 957 & 13,669 & 11,936 & 4,803 & 11,235 & 6,148 & 13,738 & 15,378 & 781 \\
\hline Q4 & 3,221 & 8,900 & 2,461 & 7,700 & 7,563 & 6,162 & 11,485 & 3,692 & 8,964 & 10,887 & 4,259 \\
\hline LKL, Q3 & 678 & 1,285 & 0 & 1,667 & 436 & 0 & 1,272 & 440 & 1,739 & 1,762 & 0 \\
\hline Q4 & 1,098 & 421 & 0 & 1,457 & 800 & 1,295 & 1,152 & 353 & 1,514 & 1,559 & 0 \\
\hline KLR, Q3 & 0 & 0 & 0 & 806 & 0 & 214 & 827 & 0 & 849 & 794 & 0 \\
\hline Q4 & 0 & 0 & 0 & 726 & 0 & 0 & 756 & 0 & 755 & 0 & 0 \\
\hline Total & 29,610 & 44,949 & 6,103 & 61,161 & 47,521 & 13,945 & 42,577 & 35,948 & 64,459 & 68,655 & 6,049 \\
\hline Demand & 29,610 & 44,949 & 6,103 & 69,198 & 47,521 & 13,945 & 42,577 & 35,948 & 68,945 & 69,162 & 6,049 \\
\hline
\end{tabular}

\begin{tabular}{|c|c|c|c|c|c|c|c|c|c|c|c|}
\hline \multirow{2}{*}{$\begin{array}{l}\text { Pumping } \\
\text { region and } \\
\text { water-year } \\
\text { quarter }\end{array}$} & \multicolumn{11}{|c|}{ Water year } \\
\hline & 1990 & 1991 & 1992 & 1994 & 1997 & 1999 & 2000 & 2001 & 2002 & 2003 & 2004 \\
\hline KLV, Q3 & 10,144 & 10,294 & 9,508 & 10,126 & 0 & 703 & 0 & 10,090 & 6,149 & 4,613 & 4,585 \\
\hline Q4 & 9,368 & 8,725 & 4,472 & 9,169 & 0 & 703 & 2,108 & 8,784 & 7,386 & 1,949 & 5,743 \\
\hline NTL, Q3 & 9,879 & 10,050 & 10,322 & 10,048 & 0 & 1,259 & 0 & 8,697 & 8,083 & 9,606 & 4,553 \\
\hline Q4 & 7,337 & 8,092 & 8,064 & 7,338 & 2,106 & 3,862 & 1,776 & 4,839 & 7,477 & 5,240 & 4,025 \\
\hline STL, Q3 & 15,902 & 16,303 & 15,833 & 15,213 & 0 & 0 & 1,796 & 14,372 & 11,456 & 7,144 & 15,930 \\
\hline Q4 & 11,012 & 13,204 & 12,805 & 9,680 & 0 & 6,812 & 4,413 & 9,240 & 6,561 & 1,806 & 7,976 \\
\hline LKL, Q3 & 1,699 & 1,682 & 457 & 1,682 & 0 & 0 & 0 & 1,661 & 1,377 & 446 & 0 \\
\hline Q4 & 1,493 & 1,647 & 377 & 1,463 & 592 & 0 & 157 & 1,426 & 1,253 & 1,702 & 0 \\
\hline KLR, Q3 & 835 & 0 & 0 & 820 & 0 & 823 & 0 & 214 & 124 & 895 & 0 \\
\hline Q4 & 137 & 0 & 0 & 735 & 0 & 0 & 0 & 734 & 190 & 827 & 0 \\
\hline Total & 67,806 & 69,997 & 61,838 & 66,274 & 2,698 & 14,162 & 10,250 & 60,057 & 50,056 & 34,228 & 42,812 \\
\hline Demand & 92,415 & 102,466 & 69,198 & 83,686 & 2,698 & 14,162 & 10,250 & 66,463 & 50,056 & 34,228 & 42,812 \\
\hline
\end{tabular}




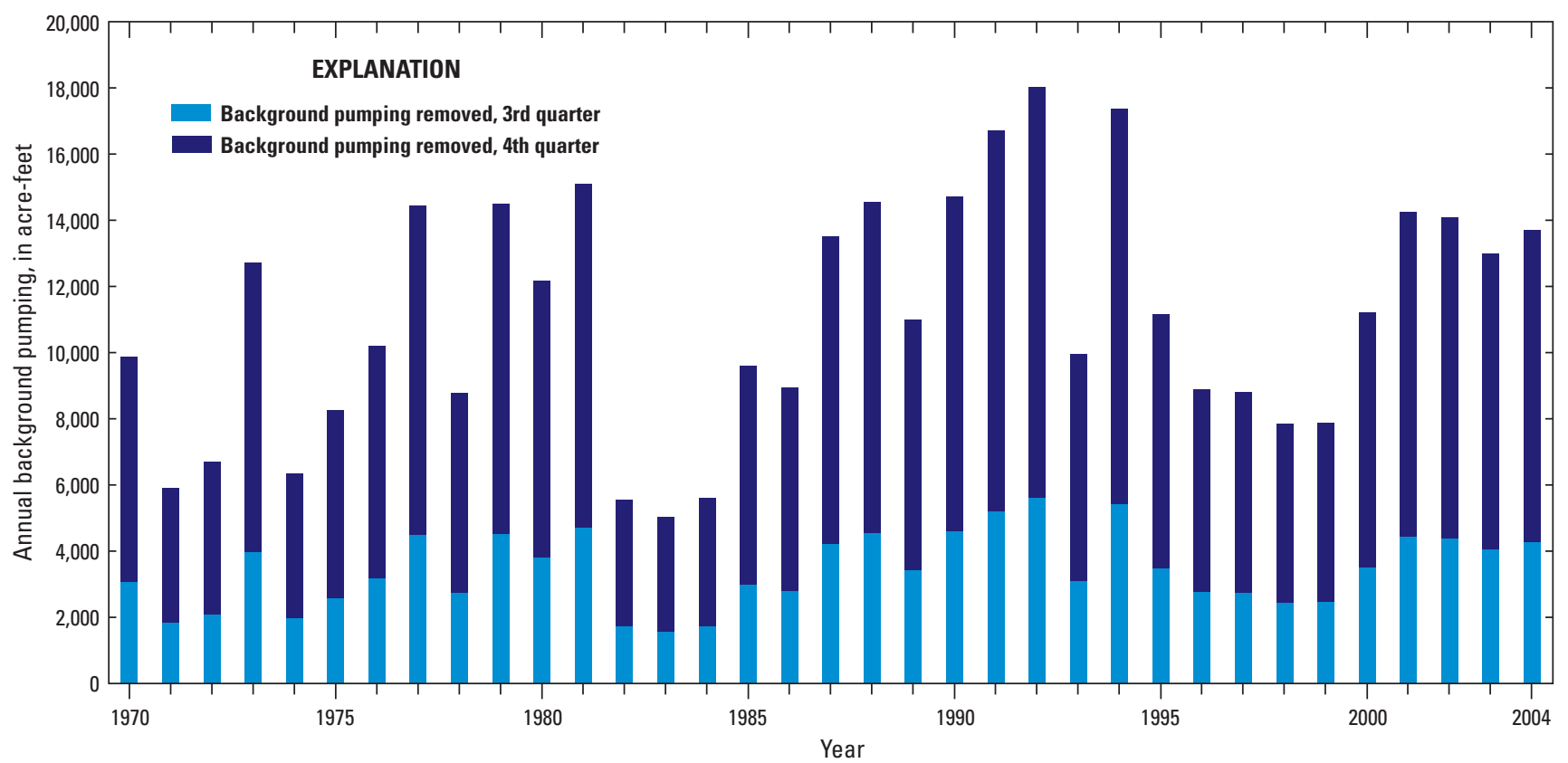

Figure 17. Summary of background pumping removed from model, upper Klamath Basin, Oregon and California, 19702004.

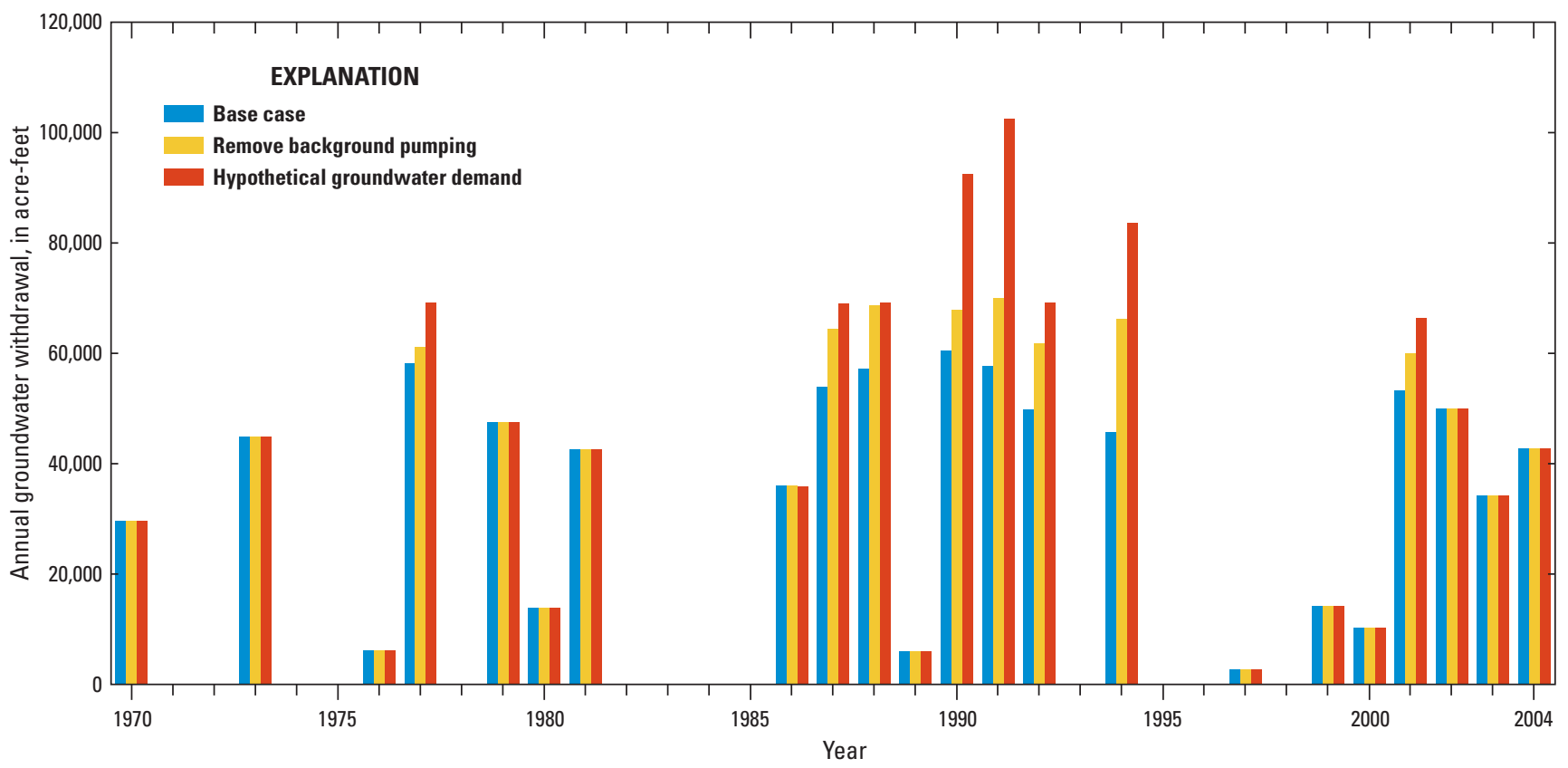

Figure 18. Sensitivity of optimization results to removal of selected background pumping, upper Klamath Basin, Oregon and California, 1970-2004. Base-case and Remove background pumping are groundwater-management-model formulations defined in table 1. 
Annual pumping amounts for the southern Tule Lake, northern Tule Lake, and Klamath Valley well groups are shown in figure 19. Compared with the withdrawals calculated for the base-case analysis, the removal of background pumping results in substantial increases in the amounts pumped in the northern Tule Lake region, which has a high concentration of binding drawdown constraints in the base-case analysis and substantial amounts of offProject groundwater pumping. The increases in calculated withdrawals of the northern Tule Lake well group range from
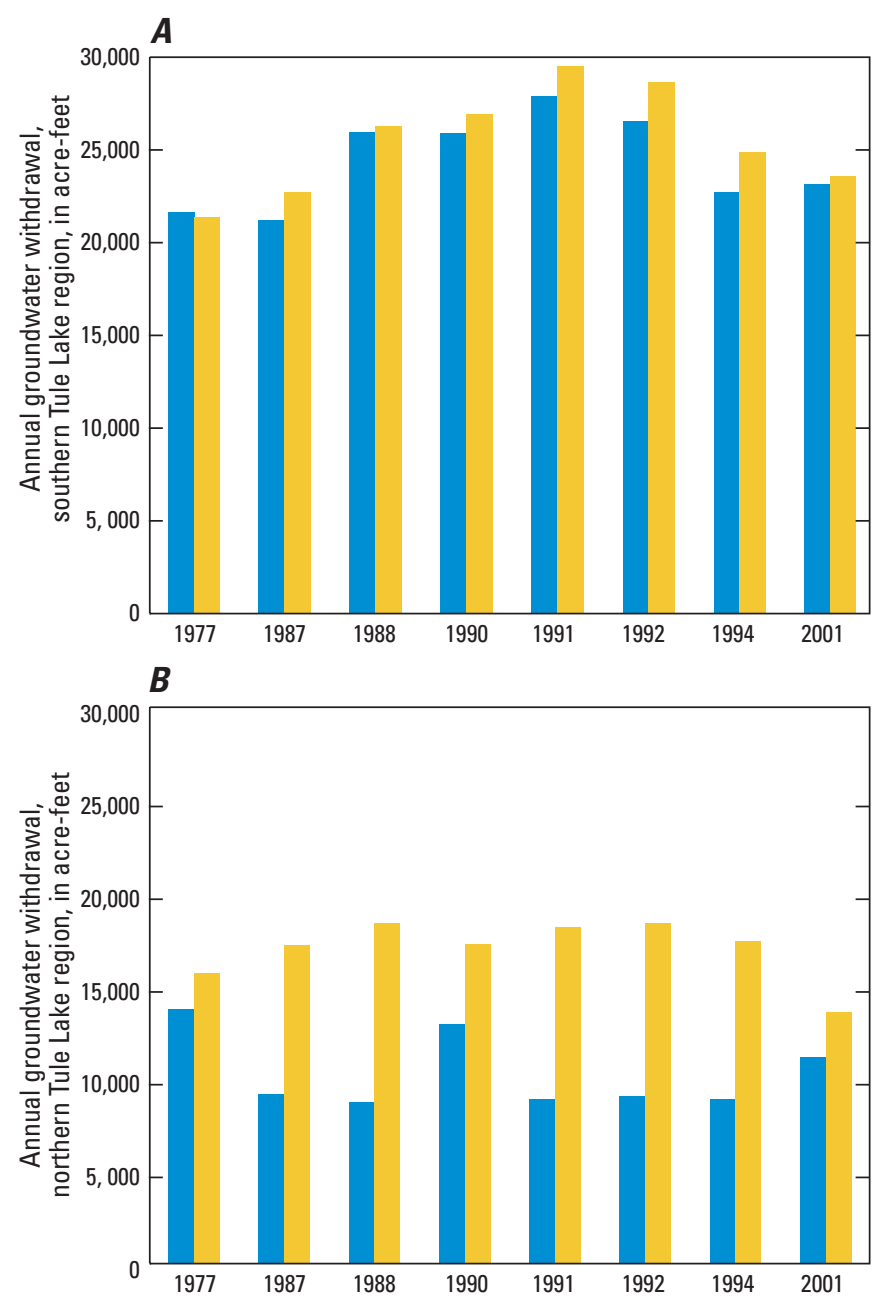

about 2,000 acre-ft to about 10,000 acre-ft, with five years having increases greater than 8,000 acre-ft (fig. 19B). The changes in pumping volumes for the southern Tule Lake and Klamath Valley wells generally are small when compared with the results of the base-case analysis. The pumping volumes associated with the southern Tule Lake well group increase by amounts as much as about 2,000 acre-ft (fig. 19A), and the pumping volumes associated with the Klamath Valley well group increase by small amounts in all years except 1994, which has an increase of about 9,000 acre-ft (fig. 19C).

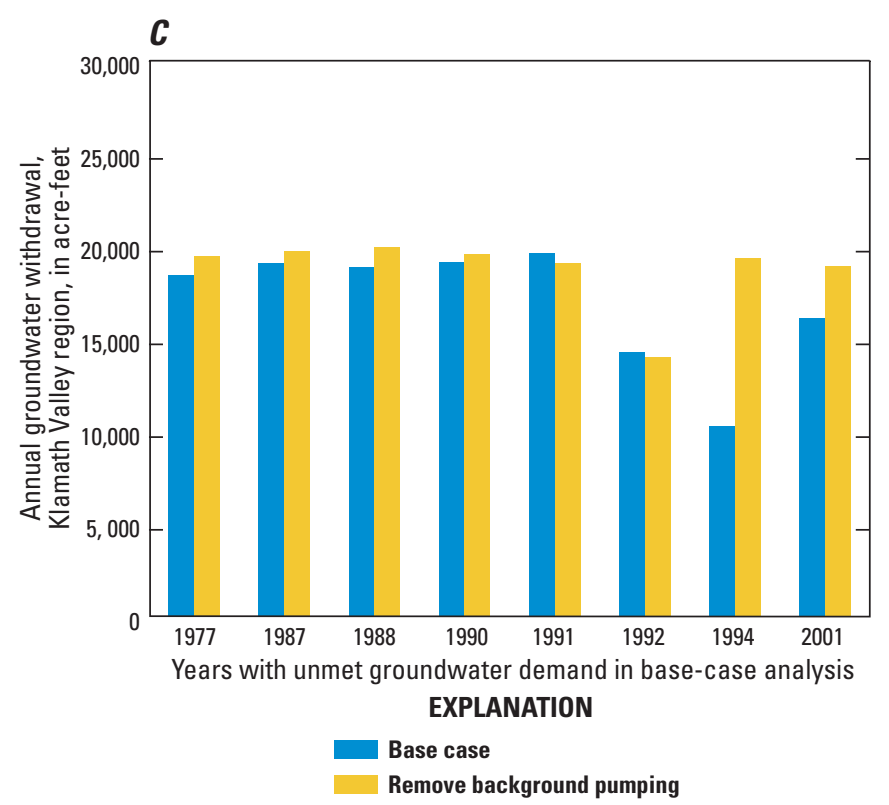

Figure 19. Calculated annual groundwater withdrawals by pumping region for the base-case analysis and analysis of reduced background pumping for $(A)$ annual pumping in the southern Tule Lake region; $(B)$ annual pumping in the northern Tule Lake region; and $(C)$ annual pumping in the Klamath Valley region, upper Klamath Basin, Oregon and California, 1970-2004. Results shown are for the years with unmet groundwater demand in the base-case groundwater-management analysis. Base-case and Remove background pumping are groundwater-managementmodel formulations defined in table 1. 


\section{Limitations of the Groundwater- Management Model}

The groundwater-management model described in this report is a simplification of the complex and multi-faceted issues associated with groundwater management in the upper Klamath Basin. The groundwater-management model identifies groundwater-pumping plans that, to the extent possible, meet the Project supplemental groundwater demand while avoiding adverse effects to groundwater and surfacewater resources. The groundwater-management model was formulated in consultation with groundwater users and resource-management agencies in the study area, and the objective and constraints were defined to capture the essential goals and policy elements associated with supplemental groundwater use by the Project. As with all optimization models, opportunities for error occur in the formulation of the groundwater-management problem (equations 1-11). Errors may occur because the management objective is misidentified, constraints are misidentified or omitted, or constraint limits are unknown. The logical next step would be to refine the groundwater-management model to include management goals, regulatory limits, and (or) operational considerations not identified in this study.

The groundwater-management model defined by equations $1-11$ is a deterministic analysis that does not consider uncertainties associated with the groundwatersimulation model, which is a simplified mathematical representation of the complex regional groundwater-flow system in the upper Klamath Basin. Uncertainty is an element of every groundwater-simulation model and can arise with respect to the processes that control groundwater flow, or with respect to the parameters that define those processes, or both. A discussion of the sources of uncertainty in the upper Klamath Basin groundwater-simulation model is available in Gannett and others (2012). As a result of model uncertainty, the simulated responses to groundwater pumping that are embedded in the groundwater-management model also are uncertain. The method of stochastic optimization addresses groundwater-simulation-model uncertainty by using the concept of reliability and identifying groundwatermanagement strategies that have a desired probability of success (Freeze and Gorelick, 1999). Although stochastic optimization techniques are available to solve the groundwater management problem, that analysis is beyond the scope of this project.
Because climate can influence supplemental groundwater needs in the upper Klamath Basin, the analysis of groundwater-management alternatives involves making assumptions about plausible climate conditions. The results provided in this report are based on the historical climate conditions observed during 1970-2004. Global climate models, however, project that changing precipitation patterns in the Pacific Northwest likely will result in changes to the amount, timing, and spatial distribution of groundwater recharge (Stewart and others, 2004; Intergovernmental Panel on Climate Change, 2007; Waibel and others, 2013). Any change to the general patterns of groundwater recharge could affect the availability of groundwater as a supplemental irrigation supply. The groundwater-management analysis described in this report could be enhanced by considering an array of plausible future climate conditions and assessing groundwater-management alternatives for a range of climate and water-use scenarios. A general discussion of waterresources management in the presence of climate change is available in Brekke and others (2009).

Groundwater-management decisions in the upper Klamath Basin may need to be modified to account for uncertainties associated with the groundwater-flow model and future climate conditions. Adaptive management is an approach used to make decisions sequentially over time and adjustments can be made as new information becomes available (Williams and others, 2007; Brekke and others, 2009). The adaptive management approach is useful for any dynamic system where there is uncertainty about the system response to management actions, such as the predicted effects of pumping on groundwater levels and discharge. In the context of groundwater management in the upper Klamath Basin, the adaptive management approach would follow an iterative process: (1) design and implement a plan for supplemental groundwater pumping by the Project, (2) monitor the effects of on-Project groundwater pumping, (3) evaluate the effects of on-Project pumping in relation to model simulations, and (4) adjust the groundwatermanagement plan as model-simulation errors are observed. Because adaptive management requires flexibility to change management decisions when presented with new information, it is best suited to guide operational decisions, such as the amount to be pumped at existing wells, rather than changes in infrastructure, such as the construction of new wells.

If an adaptive-management approach is to be applied in the upper Klamath Basin, a central element will be a groundwater-monitoring plan that provides data to reduce uncertainty and inform decision making. The focus of the 
monitoring plan should follow the focus of the groundwatermanagement program it supports. In the upper Klamath Basin, groundwater management focuses on avoiding adverse effects caused by excessive drawdown and reductions in groundwater discharge to surface water, and estimates of water levels and discharge are directly included in the management-model constraints that limit these effects. A groundwater-monitoring plan should include elements to track these critical variables. Although the design of a groundwater-monitoring plan is beyond the scope of this report, it is possible to identify some key elements of a sound monitoring program: (1) targeted monitoring at sites where water levels or discharge are expected to reach limiting values because of supplemental on-Project groundwater pumping, (2) a monitoring schedule that tracks changes in water levels and discharge during periods of supplemental groundwater use as well as between irrigation seasons and during extended periods with no on-Project groundwater pumping, and (3) a monitoring component designed to assess the effects of climate variability on water levels and discharge.

\section{Summary}

Since 2001, water-management goals in the upper Klamath Basin, Oregon and California, have shifted to protect aquatic habitat. As a result, groundwater has become an important supplemental water supply for irrigators in the Bureau of Reclamation Klamath Irrigation Project (Project), particularly during periods of drought. The potential effects of increased groundwater development on groundwater and surface-water resources have caused concern among stakeholders in the basin. This report describes the development and application of a groundwater-management model for the Project that was designed to simultaneously consider the groundwater demands of the Project and the adverse effects of concern to resourcemanagement agencies.

The overall goal of the groundwater-management model was to determine the volumes and patterns of groundwater pumping that, to the extent possible, meet the supplemental groundwater needs of the Project. The objective of the model was to maximize irrigation-season pumping at 117 wells that historically have been used to provide supplemental groundwater to the Project. Total withdrawals were limited by the groundwater demand foreseen under the Klamath Basin Restoration Agreement (KBRA) with a set of constraints defined to limit the adverse effects of supplemental groundwater pumping. These constraints were formulated to

(1) limit reductions in groundwater discharge to streams and lakes that provide critical aquatic habitat, (2) control drawdowns throughout the Project and adjacent areas, and (3) limit reductions in groundwater discharge to the Project agricultural drain system.

Six sets of applications of the groundwater-management model were completed to determine the limits of groundwater development for various groundwater-management scenarios. Baseline conditions were defined using the period 1970-2004 and supplemental groundwater demand by the Project during this period was defined as the part of estimated irrigation demand that would not be satisfied by the surface-water diversion allowed under the Klamath Basin Restoration Agreement. The results of the groundwater-management modeling analyses are summarized in the following table (shading shows constraint limits that are changed from basecase values).

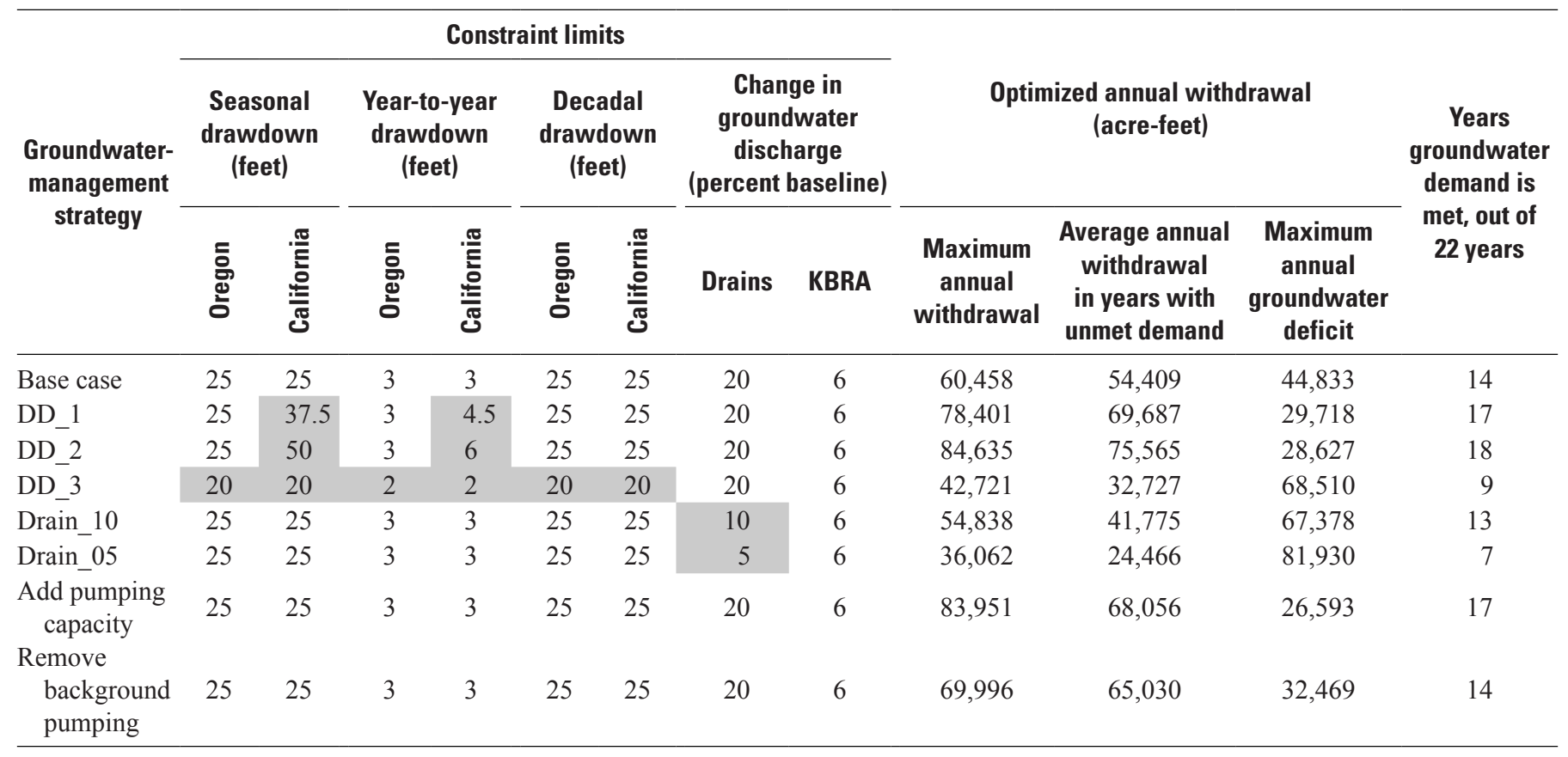


The first application of the groundwater-management model limited the reductions in groundwater discharge to critical aquatic habitat to be no more than 6 percent, as defined in the KBRA; applied drawdown limits of 25 feet (ft) for seasonal drawdown, $3 \mathrm{ft}$ for year-to-year drawdown, and $25 \mathrm{ft}$ for 10-year drawdown, as required by the Oregon Water Resources Department; and limited the reductions in groundwater discharge to the Project's drain system to be no more than 20 percent. Results indicated that the supplemental irrigation wells in the Project would be able to meet groundwater demand in 14 of the 22 years studied with supplemental groundwater needs, with a maximum calculated groundwater withdrawal of about 60,000 acre-feet (acre-ft). Significant irrigation shortages would remain in the years with unmet groundwater demand; average annual withdrawals for those years was about 54,000 acre-ft and groundwater-pumping deficits ranged from 11,000 to 45,000 acre-ft. The patterns of groundwater withdrawal calculated by the groundwatermanagement model indicated that supplemental groundwater pumping should be concentrated in the Tule Lake and Klamath Valley regions of the Project. The highest annual withdrawals occurred in the southern Tule Lake wells, which provided the highest percentage of pumping in most years and supplied about 22,000-28,000 acre-ft in the years with unmet groundwater demand. Calculated withdrawals from the Klamath Valley wells totaled about 10,000-20,000 acre-ft in the years with unmet groundwater demand, and the withdrawals from the northern Tule Lake wells totaled about 8,700-14,000 acre-ft in years with unmet demand.

Subsequent analyses evaluated the sensitivity of the optimization results to several factors. Sensitivity analyses demonstrated that substantial increases in total groundwater withdrawal could be achieved by increasing the seasonal and year-to-year drawdown limits in the California part of the Project. When the seasonal and year-to-year drawdown limits in the California part of the model were increased to 37.5 and $4.5 \mathrm{ft}$, respectively, the maximum annual withdrawal was about 78,000 acre-ft, the average annual withdrawal in years with unmet groundwater demand was about 70,000 acre-ft, and the maximum groundwater deficit was about 30,000 acre- $\mathrm{ft}$. Alternatively, when the seasonal and year-to-year drawdown limits were increased to 50 and $6 \mathrm{ft}$, respectively, the maximum annual withdrawal was about 85,000 acre-ft, the average annual withdrawal in years with unmet groundwater demand was about 76,000 acre-ft, and the maximum amount of unmet groundwater demand was about 29,000 acre-ft. In both cases, the increased withdrawals occurred primarily in the southern Tule Lake well group, which is entirely in the California part of the model.

A second sensitivity analysis evaluated the effects of imposing more restrictive drawdown limits across the entire Project. The groundwater management model calculated substantial reductions in annual withdrawals when the seasonal, year-to-year, and 10-year drawdown limits were reduced to 20, 2 , and $20 \mathrm{ft}$, respectively. The maximum annual withdrawal was calculated to be about 43,000 acre-ft and the average annual withdrawal during years with unmet groundwater demand was about 33,000 acre-ft. In comparison to the base-case analysis, total annual withdrawals calculated for the years with unmet groundwater demand were reduced by as much as 27,000 acre-ft, with the largest reductions in the Klamath Valley and southern Tule Lake well groups. With the more restrictive drawdown limits, expected groundwater needs were met in only 9 of the 22 years studied and the maximum amount of unmet groundwater demand was about 69,000 acre-ft.

A third set of model applications evaluated the influence of uncertainty associated with the constraints controlling groundwater discharge to the Project agricultural drain system that collects irrigation return flows and routs them to downslope irrigators and wildlife refuges. A two-part sensitivity analysis determined the change in pumping volume and distribution associated with a more restrictive constraint on the allowable reduction in groundwater discharge to the Project drain system. The groundwater-management model calculated substantial reductions in annual withdrawals when the drains-constraint limit was reduced below the base-case limit of 20 percent. When the drains-constraint limit was set to 10 percent, the maximum annual withdrawal is about 55,000 acre-ft, the average annual withdrawal in years with unmet groundwater demand was about 42,000 acre-ft, and the maximum groundwater deficit was about 67,000 acre-ft. With the constraint limit set to 5 percent, the maximum annual withdrawal was about 36,000 acre-ft, the average withdrawal in years with unmet groundwater demand was about 25,000 acre- $\mathrm{ft}$, and the maximum amount of unmet groundwater demand was about 82,000 acre-ft. The patterns of groundwater withdrawal calculated by the groundwater-management model indicated that the largest reductions in pumping occur in the southern Tule Lake well group, which generally have the highest annual pumping volumes in the base-case model.

Additional applications of the groundwater-management model evaluated the trade-offs associated with increasing the pumping capacity of the network of wells serving the Project and reducing background pumping at wells in the vicinity of the Project. A sensitivity analysis assessed the potential value of additional pumping capacity at existing decision wells by increasing the well-capacity constraint limits and re-solving the groundwater-management model. The optimization model identified the potential for increased pumping at a small set of wells in the Klamath Valley well group in Oregon. The maximum annual withdrawal for this analysis was about 84,000 acre-ft and the average annual withdrawal in years with unmet groundwater demand is about 70,000 acre-ft. Similarly, the model identified the potential to increase annual pumping amounts by removing off-Project background pumping. 
Simulated background pumping was removed from areas that were likely to impact groundwater levels at locations with binding drawdown constraints. The optimization model was then re-solved to determine the change in pumping volumes at on-Project wells. The results of the updated groundwatermanagement model indicated that increased withdrawals, primarily from the northern Tule Lake region, would result from the removal of background pumping. The maximum annual withdrawal was about 70,000 acre-ft and the average annual withdrawal in years with unmet groundwater demand was about 65,000 acre-ft.

The results of the groundwater-management model presented in this report demonstrate the value of a coupled groundwater-simulation and optimization model for evaluating groundwater-management issues in the upper Klamath Basin. The groundwater-management model provides an improved understanding of the capacity for, and limitations of, increased supplemental groundwater pumping. The results of the groundwater-management model demonstrate that groundwater can serve as an important supplemental irrigation supply for the Bureau of Reclamation Klamath Irrigation Project and that supplemental groundwater use by the Project can be managed to avoid adverse effects to groundwater discharge that supports aquatic habitat. Groundwater-management results presented in this report may need to be modified to account for model uncertainty and climate conditions not represented in this study. As a result, next steps in the application of a groundwatermanagement strategy in the upper Klamath Basin should follow an adaptive management approach that includes a groundwater monitoring program designed to track the effects of on-Project supplemental groundwater pumping.

\section{Acknowledgments}

The authors would like to acknowledge the irrigation community, groundwater users, and resource-management agencies of the upper Klamath Basin for the guidance they provided. Ivan Gall, Kenneth Lite, and Douglas Woodcock (Oregon Water Resources Department) and Seth Lawrence (California Department of Water Resources) all provided valuable insights into regulatory agency perspectives. Valuable data and insights regarding the operation of the Klamath Project were provided by Hollie Cannon (Klamath Water and Power Agency) and Mark Van Camp and Sara Harper (MBK Engineers). We are grateful to Peter Lawson and Justin Lanier (CH2M Hill) for important discussions of groundwater modeling and management in the upper Klamath Basin. We also thank Paul Barlow and Tracy Nishikawa for their helpful technical reviews of this report. This work was funded by the USGS Cooperative Water Program, USGS National Research Program, the Klamath Water and Power Agency, and the Oregon Water Resources Department.

\section{References Cited}

Ahlfeld, D.P., and Baro-Montes, G., 2008, Solving unconfined groundwater flow management problems with successive linear programming: Journal of Water Resources Planning and Management, v. 134, no. 5, p. 404-412.

Ahlfeld, D.P., and Mulligan, A.E., 2000, Optimal management of flow in groundwater systems: San Diego, Calif., Academic Press, 185 p.

Barlow, P.M, and Dickerman, D.C., 2001, Numericalsimulation and conjunctive-management models of the Hunt-Annaquatucket-Pettaquamscutt stream-aquifer system, Rhode Island: U.S. Geological Survey Professional Paper 1636, 88 p., http://pubs.usgs.gov/pp/pp1636/.

Barlow, P.M, Wagner, B.J., and Belitz, K., 1996, Optimal pumping strategies for control of the shallow water table in California's western San Joaquin Valley-The value of the simulation-optimization approach: Ground Water, v. 34, no. 2, p. 305-317.

Brekke, L.D., Kiang, J.E., Olsen, J.R., Pulwarty, R.S., Raff, D.A., Turnipseed, D.P., Webb, R.S., and White, K.D., 2009, Climate change and water resources management-A federal perspective: U. S. Geological Survey Circular 1331, 65 p., http://pubs.usgs.gov/circ/1331/.

Burt, C., and Freeman, B., 2003, Klamath Basin investigation-Hydrologic assessment of the Upper Klamath Basin, Issues and opportunities, draft report: San Luis Obispo, California Polytechnic State University, Irrigation Training and Research Center (ITRAC), Prepared for the U.S. Bureau of Reclamation, variously paged.

California Department of Water Resources, 1998, Butte Valley Wildlife Area well interference investigation: California Department of Water Resources, Northern District, 102 p.

California Department of Water Resources, 2003, California's groundwater: California Department of Water Resources Bulletin 118 (update 2003), 246 p.

California Department of Water Resources, 2003, Tule Lake subbasin-Hydrogeologic investigation: California Department of Water Resources Draft Report, 46 p.

Carlson, H.L., and Todd, Rodney, 2003, Effects of the 2001 water allocation decisions on the agricultural landscape and crop production in the Klamath Reclamation Project, in Braunworth, W.S., Jr., Welch, Teresa, and Hathaway, Ron, eds., Water allocation in the Klamath Reclamation ProjectAn assessment of natural resource, economic, social, and institutional issues with a focus on the upper Klamath Basin: Oregon State University Extension Service Special Report 1037, p. 163-167. 
Danskin, W.R., and Freckleton, J.R., 1989, Ground-water-flow modeling and optimization techniques applied to highground-water problems in San Bernardino, California: U.S. Geological Survey Open-File Report 89-75, 14 p.

Danskin, W.R., and Gorelick, S.M., 1985, A policy evaluation tool-Management of a multiaquifer system using controlled stream recharge: Water Resources Research, v. 21, no. 11, p. $1,731-1,747$.

DeSimone, L.A., Walter, D.A., Eggleston, J.R., and Nimiroski, M.T., 2002, Simulation of ground-water flow and evaluation of water-management alternatives in the upper Charles River Basin, Eastern Massachusetts: U.S. Geological Survey Water Resources Investigations Report 02-4234, $94 \mathrm{p}$.

Freeze, R.A., and Gorelick, S.M., 1999, Convergence of stochastic optimization and decision analysis in the engineering design of aquifer remediation: Groundwater, v. 37 , no. 6 , p. 934-954.

Gall, I., 2011, Technical assistance for the U.S. Bureau of Reclamation water bank in the upper Klamath Basin 2011: Salem, Oreg., Oregon Water Resources Department, 39 p.

Gannett, M.W., Lite, K.E., Jr., La Marche, J.L., Fisher, B.J., and Polette, D.J., 2007, Ground-water hydrology of the upper Klamath Basin, Oregon and California: U.S. Geological Survey Scientific Investigations Report 2007-5050, 84 p., http://pubs.usgs.gov/sir/2007/5050/.

Gannett, M.W., Wagner, B.J., and Lite, K.E. Jr., 2012, Groundwater simulation and management models for the upper Klamath Basin, Oregon and California: U.S. Geological Survey Scientific Investigations Report 2012-5062, 92 p., http://pubs.usgs.gov/sir/2012/5062/.

Gorelick, S.M., 1983, A review of distributed parameter groundwater management modeling methods: Water Resources Research, v. 19, no. 2, p. 305-319.

Gorelick, S.M., Freeze, R.A., Donohue, D., and Keely, J.F., 1993, Groundwater contamination - Optimal capture and containment: Boca Raton, Fla., Lewis Publishers, 385 p.

Granato, G.E., and Barlow, P.M., 2004, Effects of alternative instream-flow criteria and water-supply demands on ground-water development options in the Big River Area, Rhode Island: U.S. Geological Survey Scientific Investigations Report 2004-5301, 110 p., http://pubs.usgs.gov/sir/2004/5301/.

Grondin, G.H., 2004, Ground water in the eastern Lost River sub-basin, Langell, Yonna, Swan Lake, and Poe Valleys of Southeastern Klamath County, Oregon: Oregon Water Resources Department Groundwater Report No. 41, 167 p.
Hotchkiss, W.R., 1968, A geologic and hydrologic reconnaissance of Lave Beds National Monument and vicinity, California: U.S. Geological Survey Open-File Report 68-140, 30 p.

Hubbard, L.H., 1970, Water budget of Upper Klamath Lake southwestern Oregon: U.S. Geological Survey Hydrologic Investigations Atlas HA-351, 1 sheet, scale 1:250,000.

Intergovernmental Panel on Climate Change, 2007, Climate change 2007-The physical science basis - Contribution of working group 1 to the fourth assessment report of the IPCC: Cambridge University Press, 996 p.

Klamath Basin Restoration Agreement (KBRA), 2010, Klamath Basin restoration agreement for the sustainability of public and trust resources and affected communities: Klamath Basin Water Issues Web site, accessed August 29, 2011, at http://klamathrestoration.gov/.

Klamath Water Users Association, 2011, Klamath Water Users Association annual report 2010: Klamath Water Users Association, Klamath Falls, Oreg, 21 p.

La Rue, E.C., 1922, Klamath River and its utilization: Salem, Oreg., Report to the Office of the State Engineer, 204 p.

Leonard, A.R., and Harris, A.B., 1974, Ground water in selected areas in the Klamath Basin, Oregon: Oregon State Engineer Ground Water Report No. 21, 104 p.

LINDO Systems, Inc., 2005, LINDO ${ }^{\circledR}$ API: Chicago, Ill., LINDO Systems, Inc., 459 p.

McDonald, M.G., and Harbaugh, A.W., 1988, A modular three-dimensional finite-difference ground-water flow model: U.S. Geological Survey Techniques of Water Resources Investigations, book 6, chap. A1, 586 p.

McFarland, W., Gannett, M.W., Risley, J., Lynch, D., Miller, J., McCarthy, K., Snyder, D., and Morgan, D., 2005, Assessment of the Klamath project pilot water bank-A review from a hydrologic perspective: Prepared by the U.S. Geological Survey for the Bureau of Reclamation, $98 \mathrm{p}$, accessed November 26, 2013, at http://www.usbr.gov/mp/ $\mathrm{kbao} / \mathrm{docs} /$ Final_USGS_Assessment_of_Water_Bank.pdf.

MBK Engineers and others, 2012a, Water supply and operations for the on-project plan area: Prepared for Klamath Water and Power Agency, Technical Memorandum 2, 98 p., accessed November 5, 2013, at http://kwapa.org/.

MBK Engineers, and others, 2012b, Supplemental water need of the on-project plan area: Prepared for Klamath Water and Power Agency, Technical Memorandum 4, 41 p., accessed November 5, 2013, at http://kwapa.org/. 
National Marine Fisheries Service and U.S. Fish and Wildlife Service, 2013, Biological Opinions on the effects of proposed Klamath Project operations from May 31, 2013 through March 31, 2023, on five federally listed threatened and endangered species: National Marine Fisheries Service, Southwest Region, 590 p., accessed November 5, 2013, at http://www.usbr.gov/mp/kbao/docs/Klamath_Project_ Biological_Opinion.pdf.

National Research Council, 2004, Endangered and threatened fishes in the Klamath River Basin - Causes of decline and strategies for recovery: Washington, D.C., The National Academies Press, 397 p.

Natural Resources Conservation Service, 2004, Summary of the upper Klamath Basin rapid subbasin assessment of private lands: U.S. Department of Agriculture, Natural Resources Conservation Service, variously paged.

Newcomb, R.C., and Hart, D.H., 1958, Preliminary report on the ground water resources of the Klamath River Basin, Oregon: U.S. Geological Survey Open-File Report [unnumbered], $248 \mathrm{p}$.

Nishikawa, T., 1998, Water-resources optimization model for Santa Barbara, California: Journal of Water Resources Planning and Management, v. 124, no. 5, p. 252-263.

Oregon Water Resources Department, 2011, Oregon administrative rules, chap. 690, Division 8, Statutory Ground Water Terms: Salem, Oreg., Oregon Water Resources Department, accessed August 30, 2011, at http://www.oregon.gov/owrd/pages/law/oar.aspx.

Reichard, E.G., Land, M., Crawford, S.M., Johnson, T., Everett, R.R., Kulshan, T.V., Ponti, D.J., Halford, K.J., Johnson, T.A., Paybins, K.S., and Nishikawa, T., 2003, Geohydrology, geochemistry, and ground-water simulationoptimization of the central and west coast basins, Los Angeles County, California: U.S. Geological Survey Water Resources Investigations Report 03-4065, 184 p.

Risley, J.C., and Gannett, M.W., 2006, An evaluation and review of water-use estimates and flow data for the Lower Klamath and Tule Lake national wildlife refuges, Oregon and California: U.S. Geological Survey Scientific Investigations Report 2006-5036, 18 p., http://pubs.usgs.gov/sir/2006/5036/.
Reilly, T.E., Dennehy, K.F., Alley, W.M., and Cunningham, W.L., 2008, Ground-water availability in the United States: U.S. Geological Survey Circular 1323, 70 p., http://pubs.usgs.gov/circ/1323/.

Snyder, D.T., and Morace, J.L., 1997, Nitrogen and phosphorous loading from drained wetlands adjacent to Upper Klamath and Agency Lakes, Oregon: U.S. Geological Survey Water-Resources Investigations Report 97-4059, $67 \mathrm{p}$.

Stewart, I.T., Cayan, D.R., and Dettinger, M.D., 2004, Changes in snowmelt runoff timing in western North America under a "business as usual" climate change scenario: Climate Change, v. 62, p. 217-232.

U.S. Department of the Interior, U.S. Department of Commerce, and National Marine Fisheries Service, 2012, Klamath Dam removal overview report for the Secretary of the Interior-An assessment of science and technical information: U.S. Department of the Interior, 399 p., accessed January 29, 2013, at http://www.klamathrestoration.gov/.

Wagner, B.J., 1995, Recent advances in simulationoptimization groundwater management modeling: Reviews of Geophysics (supplement 33), p. 1,021-1,028.

Waibel, M.S., Gannett, M.G., Chang, H., and Hulbe, C.L., 2013, Spatial variability of the response to climate change in regional groundwater systems-Examples for simulations in the Deschutes Basin, Oregon: Journal of Hydrology, v. 486, p. 187-201.

Western Regional Climate Center, 2013, Cooperative climatological data summaries, Oregon: Western Regional Climate Center, accessed November 5, 2013, at http://www.wrcc.dri.edu/summary/Climsmor.html.

Williams, B.K., Szaro, R.C., and Shapiro, C.D., 2007, Adaptive management-The U.S. Department of the Interior technical guide: Washington D.C., U.S. Department of the Interior Adaptive Management Working Group, $82 \mathrm{p}$.

Wood, P.R., 1960, Geology and ground-water features of the Butte Valley region, Siskiyou County, California: U.S. Geological Survey Water-Supply Paper 1491, 150 p.

Yeh, W. W-G., 1992, Systems analysis in ground-water planning and management: Journal of Water Resources Planning and Management, v. 118, no. 3, p. 224-237. 
Publishing support provided by the U.S. Geological Survey Publishing Network, Tacoma Publishing Service Center

For more information concerning the research in this report, contact the Director, Oregon Water Science Center

U.S. Geological Survey

2130 SW 5th Avenue

Portland, Oregon 97201

http://or.water.usgs.gov 
